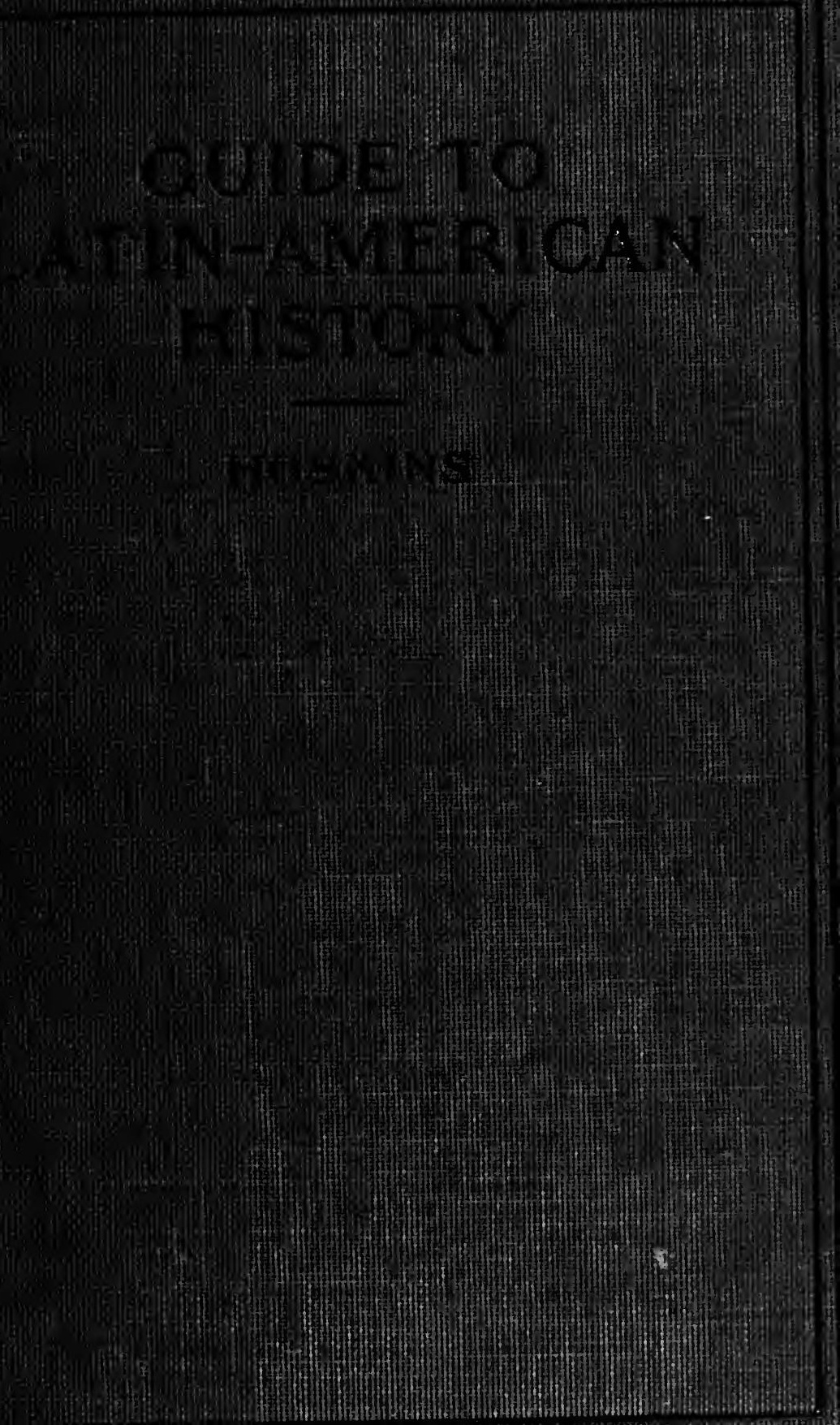



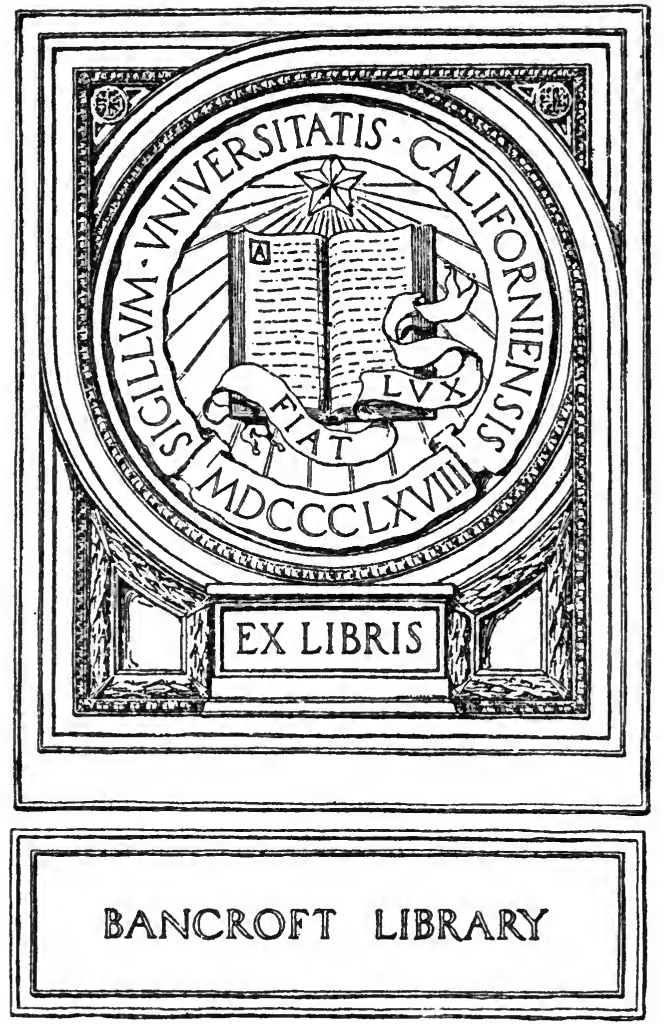
Priestley 


\section{Digitized by the Internet Archive in 2007 with funding from Microsoft Corporation}


• 


\title{
GUIDE TO LATIN-AMERICAN HISTORY
}

BY

HALFORD LANCASTER HOSKINS, $1891-$ ASSISTANT PROFESṢOR OF HISTORY AND PUBLIC LAW TUFTS COLLEGE

\author{
D. C. HEATH \& CO., PUBLISHERS


F1410

. H7

COPYRIGHT, 1922,

By D. C. Heath \& Co.

$2 \mathrm{C} 2$

PRINTED IN U.S.A 


\section{4 \\ Bancroft Library}

\section{PREFACE}

Most of the purposes of this handbook are obvious. It is intended primarily to furnish a means of access to the various aspects of development of those states which are collectively termed Latin America. Until lately little attempt has been made to study the evolution and international importance of our southern neighbors, as the paucity of comprehensive works on Hispanic America witnesses. Only with the increasing commercial importance of these states have we become aware of the existence of a number of large and potentially wealthy and powerful nations at our very door; and it must be confessed that as the origin of this interest was commercial, the basis of our concern continues to be primarily economic. Hence, we have been studying Latin-American social and cultural development largely for the purpose of understanding Latin-American business methods and opportunities.

We are coming to realize, however, that these southern republics have more to offer than mere opportunities for commercial and financial exploitation. It becomes increasingly evident that here are great nations in the making, having their own distinct types of institutions and culture, their own likes and dislikes, and, withal, a growing consciousness of self-dependence and strength which makes them constantly more worthy of consideration as friends or foes.

In a careful, sympathetic study of these budding nations we have the true germs of genuine Pan-Americanism. Only by thorough mutual understanding can all the nations of the western hemisphere develop a spirit of international coöperation based no longer on diplomatic expression of good will, but upon the recognition of common aims and interests toward the promotion of the common welfare. 
It may be that proper appreciation of the existing mutual dependence can arrive only through the strengthening of the economic bonds already created. A study of our commercial relations with Latin America shows that the two Americas are essentially inter-dependent. For that reason, a considerable portion of the accompanying syllabus has been devoted to such considerations, in the hope that through the study of this practical basis of inter-American relations there may arise a PanAmerican consciousness of common aims and interests, to which this little book is sincerely dedicated.

Tufts College

H. L. H.

February, I922 


\section{SKELETON OUTLINE}

I. The Colonial Era of Latin-American History

A. The European Background

B. The Era of Discovery and Conquest

C. Iberian Colonies and Institutions in America

II. Evolution of the Latin-American Nations

A. The Struggles for Independence

B. Rise of the South American Republics

C. Course of the Northern Latin States and Dependencies

III. Latin-American Problems and Collective Development
A. National Growth of Latin States
$B$. Contemporary Social Conditions
C. Economic and Industrial Progress

IV. PAN-American AND Internatronal Relations

A. Evolution of American Policies

$B$. Foreign Business and Trade Relations 
, 


\section{CONTENTS}

PAGE

BIBLIOGRAPHY............................. I

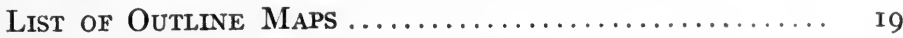

I. The Colonial ERa of Latin-AmericaN History

A. The European Background.

I. Spanish and Portuguese Origins.

a. The Racial Basis of Iberian History. . . . . . . . . 23

b. Rise of the Spanish Kingdom............... 24

c. Hispanic Life and Institutions.............. 25

2. Basis of the Expansion of Europe.

a. Forces and Factors in Colonial Expansion......... 26

b. Widening of the European Horizon........... 28

B. The Era of Discovery and Conquest.

I. The Unveiling of the New World.

a. The Finding of Western Lands.............. 29

b. Character of the New World................ 30

c. Native Life in Hispanic America.............. 3 I

2. Beginning of the Occupation of America.

a. First Stages in Colonization............... 32

b. The Conquest of Indian States............... 34

C. Iberian Colonies and Institutions in America.

I. Colonial Government and Territorial Expansion.

a. Methods of Iberian Imperial Control............ 35

b. The Rise of Spanish Agricultural Colonies......... 36

c. The Portuguese in Brazil................ 37

2. General Survey of Colonial Economic Development.

a. Trade and Colonial Competition ............. 39

b. Internal Administration of the Colonies.......... 40

c. Labor Problems and Industrial Progress......... $4^{\mathrm{I}}$

3. Eighteenth Century Social Conditions.

a. Religious Institutions in the Colonies. . . . . . . . 43

b. Phases of Social Evolution................. 44 
II. Evolution of the Latin-American Nations

$A$. The Struggles for Independence.

PAGE

I. The Liberation of Spanish South America.

a. Preliminaries of Latin-American Independence..... . 46

b. Early Phases of the Revolutionary Movements.... . . 47

c. The Final Series of South American Revolutions. . . . 48

2. Minor Revolutionary Movements.

a. The Independence of Brazil............... 50

b. Revolution in Mexico and the Caribbean.......... $\quad 5^{\mathrm{I}}$

3. The Establishment of Latin-American Independence.

a. Evolution of a Policy of American Isolation. . . . . . . 52

b. Recognition: the Monroe Doctrine............ 53

B. Rise of the South American Republics.

I. Rise of Progressive Latin-American States.

a. The Development of Argentina.............. 55

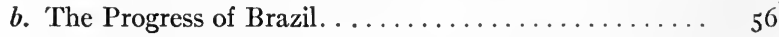

c. The Growth of Chile................. 57

d. The National History of Uruguay. . . . . . . . . $\quad 59$

2. Course of the Undeveloped Republics.

a. The Caribbean States: Venezuela and Colombia..... 60

b. The Pacific States: Ecuador and Peru........... 6I

c. The Interior States: Bolivia and Paraguay........ 63

C. Course of the Northern Latin States and Dependencies.

I. History of the Continental Republics.

a. Outline of Mexican Evolution................ 64

b. The Central American States. . . . . . . . . . . . 66

2. Island States and Colonies.

a. The West Indian Republics.................. 67

b. Foreign Colonial Possessions in Latin America. ..... 68

III. Latin-American Problems and Collective Development

4. National Growth of Latin-American States.

I. Stages in National Evolution.

a. The Age of Dictators, $1826-1852 \ldots \ldots \ldots \ldots \ldots, 70$

b. The Struggle for Political Stability, $185^{2-1} 876 \ldots \ldots$ 7I

c. The Period of National Progress, $1876-\mathrm{r} 922 \ldots \ldots \ldots .72$ 
2. Political Characteristics of Latin-American States. PAGE

a. Types of Latin-American Government. .......... 74

b. Governmental Policies and Administration........ 75

3. Latin-American Inter-State Relations.

a. Partial Disintegration and Resultant Problems..... 76

b. Aspects of Inter-State Difficulties. . . . . . . . 78

B. Contemporary Latin-American Social Conditions.

I. Analysis of Latin-American Society.

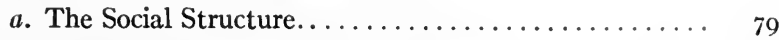

b. Types of Social and Labor Problems............ 8I

c. Aspects of Latin-American Life and Customs...... 82

2. Intellectual and Cultural Development.

a. Problems and Progress in Education........... 83

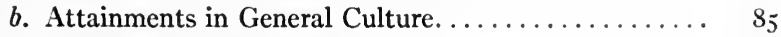

c. Evidences of Civic Spirit................ 86

C. Latin-American Economic and Industrial Progress.

I. Types of Farming Activities.

a. Plant Industries of the Tropics............ 87

b. Agricultural Development in Temperate Regions..... 88

c. Importance of Live Stock Industries.......... 90

2. Mining and Manufacturing Conditions.

a. Exploitation of Natural Resources ............ 9ा

b. Rise of Manufacturing Industries............ 92

\section{PAN-AMerican ANd International Relations}

A. Evolution of American Policies.

I. Transition Stages of the Monroe Doctrine.

a. Early Variations of the Monroe Doctrine......... 94

b. Phases of the American Doctrine.............. 95

2. The Caribbean Policy of the United States.

a. The Isthmian Canal and Its Problems ......... 97

b. Hegemony of the United States in Central America... 98

c. American Interests in the West Indies. . . . . . . . 99

3. Recent Theories of Latin-American Relations.

a. European Attitude toward the American Doctrine... Ior

b. The Latin-American Doctrine............... 102

c. Pan-Americanism................... 104 
B. Foreign Business and Trade Relations.

I. Factors in Latin-American Trade Development.

a. Monetary and Banking Conditions............ I05

b. Latin-American Business Methods............. 106

c. Features of Commercial Regulation............ 108

$d$. Problems of Internal Communication and Transportation......................... Io9

e. Shipping and Port Facilities............... I I0

2. Survey of United States Business Relations.

a. Beginnings of Economic Penetration .......... II 2

b. Obstacles to American Commercial Success........ II

3. Elements of Future Commercial Growth.

a. Shipping Methods in Latin-American Trade....... II4

b. Considerations Essential to Commercial Success...... II5

c. Efforts toward Future Trade Development........ II

Topics for Special InVEStigation $\ldots \ldots \ldots \ldots \ldots \ldots \ldots \ldots$ ing 


\section{SELECTED, CLASSIFIED BIBLIOGRAPHY}

of Materials Relating to Latin-American History

\section{Works of General Character}

A. General Histories and Textbooks.

Akers, C. E., A History of South America, 1854-1904. Dutton, 19I 2. Bryce, James, South America: Observations and Impressions. Macmillan, r9I4.

Cambridge Modern History. ro vols. Macmillan, I903-1910.

Dawson, T. C., History of South America. 2 vols. Putnam, 1903, 1904. Domville-Fife, C. W., The States of South America, The Land of Opportunity. Macmillan, I920.

Enock, C. R., The Republics of South and Central America. Scribner, r913.

Garcia-Calderon, F., Latin America: Its Rise and Progress. Scribner, 1918.

Hale, A. B., The South Americans. Bobbs-Merrill, 1907.

Jones, A. D. (trans.), The History of South America. Macmillan, 1899.

Koebel, W. H., The History of South America. (Lond.) Black, I9I3.

Latané, J. H., The United States and Latin America. Doubleday, Page, 1920.

Robertson, W. S., Rise of the Spanish American Republics. Appleton, 1918.

Shepherd, W. R., The Hispanic Nations of the New World. Yale Univ. Press, I920.

- Latin America. Holt, I917.

Sweet, W. W., A History of Latin America. Abingdon Press, 1919.

B. Descriptive Materials.

I. Travels and Descriptive Narratives.

Adams, A. A., Plateau People of South America. Dutton, 1915.

Adams, F. U., The Conquest of the Tropics. Doubleday, Page, r9i4.

Ballou, M. M., Equatorial America. Houghton Mifflin, 1892 .

Bingham, Hiram, Across South America. Houghton Mifflin. I9r. 
Brady, C. T., South American Fights and Fighters. Doubleday, Page, I9ro.

Bullard, Arthur, Panama: the Canal, the Country, the People. Macmillan, I9I4.

Clemenceau, Georges, South America Today. Putnam, I9I I.

Ford, I. N., Tropical America. Scribner, I893.

Forest, A. S., A Tour Through South America. (N. Y.) Pott, I9I2.

Franck, H. A., Roaming Through the West Indies. Century, I920. -Vagabonding Down the Andes. Century, I917.

Keane, A. H. (C. R. Markham, ed.), Central and South America. 2 vols. (Lond.) Stanford, I909, I9II.

Koebel, W. H., The Romance of the River Plate. (Lond.) Ponsonby, I9r4.

Mozans, H. J. (pseud.), Along the Andes and Down the Amazon. Appleton, I9II.

-Following the Conquistadores. Appleton, r9ro.

-The Quest of El Dorado. Appleton, r9I7.

-Through South America's Southland. Appleton, I9I6.

Up the Orinoco and Down the Magdalena. Appleton, I9ro.

Palmer, Frederick, Central America and Its Problems. (Lond.) Moffat, Yard, rgro.

Peck, Annie S., The South American Tour. Doran, I9I3.

Putnam, G. P., The Southland of North America. Putnam, I9r3.

Ross, E. A., South of Panama. Century, I915.

Ruhl, Arthur, The Other Americans. Scribner, 1908.

Squier, E. G., Adventures on the Mosquito Shore. (N. Y.) Worthington, I8gr.

Stephens, J. L., Incidents of Travel in Yucatan. Harper, $\mathrm{I} 848$.

Van Dyke, H. W., Through South America. Crowell, I9I2.

\section{Works on Social and Cultural Conditions.}

Babson, R. W., The Future of South America. Little, Brown, I915. Blakeslee, G. H. (ed.), Latin America. Clark Univ. Press, I9I4. Brandon, E. E., Latin-American Universities and Special Schools. Washington, Gov't Print. Off., I9r3.

Coester, A. L., The Literary History of Latin A merica. Macmillan, 1916. Koebel, W. H., The South Americans. Dodd, Mead, I9r5.

Lamborn, R. H., Mexican Paintings and Painters. (Phila.) Allen, r89r. Mulhall, M. G., The English in South America. (Lond.) Stanford, 1878. Neely, T. B., South America:' Its Missionary Problem. (N. Y.) Y. P. Missionary Movement, I9ro. 
Speer, R. E., Missions and Modern History. 2 vols. (N. Y.) Revell, I904.

-South American Problems. (N. Y.) Student Volunteer Movement, I9I7.

3. Atlases, Guides, and Works on Geography.

Adams, C. C., Textbook of Commercial Geography. Appleton, I9II. Bartholomew, J. G., An Atlas of Economic Geography. Oxford Univ. Press, I9I4.

Atlas of the World's Commerce. (Lond.) Newnes. 1907.

-A Literary and Historical Atlas of America. (Lond.) Dent, I9Ir.

Bowman, Israel, South America, a Geography Reader. Rand, McNally, I915.

Brigham, A. P., Commercial Geography. Ginn, I9Ir.

Chisholm, G. G., Handbook of Commercial Geography. Longmans, I9I I.

Finch, V. C., and Baker, O. E., Geography of the World's Agriculture. U. S. Dep't of Agriculture, 1917.

Hale, Albert, Practical Guide to South America. Small, Maynard, I9o9.

Hirst, W. A., Guide to South America. Macmillan, I9ro.

Keane, A. H., Stanford's Compendium of Geography and Travel. 2 vols. (Lond.) Stanford, I909, I9II.

Muir, Ramsay, Hammond's New Historical Atlas. (N. Y.) Hammond, I9I4.

Shepherd, W. R., An Historical Atlas. Holt, r921.

Terry, T. P., Terry's Mexico. Houghton, 1909.

Universal Atlas of the World. Rand, McNally, r9i4.

C. Books on Periods of Latin-American History.

I. The European Background.

Busk, Mrs. M. M., History of Spain and Portugal. London, I833.

Chapman, C. E., History of Spain. Macmillan, 1918.

Cheyney, E. P., European Background of American History. Harper, I904.

Ellis, Havelock, The Soul of Spain. Houghton, 1908.

Grant, Madison, The Passing of the Great Race. Scribner, I916.

Hale, E. E., and Susan, Spain. Putnam, I8g8.

Hume, M. A. S., Spain: Its Greatness and Decay (1479-I788). Cambridge Univ. Press, I899.

-The Spanish People. Appleton, I90r.

Lane-Poole, Stanley, The Moors in Spain. Putnam, I9r r. 
Lea, H. C., A History of the Inquisition in Spain. 4 vols. Macmillan, I906-I907.

-The Moriscos of Spain. (Phila.) Lea Bros., I90I.

Merriman, R. B., The Rise of the Spanish Empire. 2 vols. Macmillan, I9I8.

Stephens, H. M., The Story of Portugal. Putnam, rgor.

Watts, H. E., The Christian Recovery of Spain. Putnam, I90г.

\section{Aboriginal America.}

Adams, W. H. D., The Land of the Incas. (Bost.) Dana, Estes, I875.

Ballou, M. M., Aztec Land. Houghton Mifflin, I89o.

Bingham, Hiram, In the Wonderland of Peru. National Geographic Magazine, XXIV, r9г3.

Church, G. E., Aborigines of South America. (Lond.) Chapman and Hall, I9г2.

Hrdlicka, Alès, Early Man in South America. (Wash.) Gov't Print. Off., I9I2.

Huntington, Ellsworth, The Red Man's Continent. Yale Univ. Press, I920.

Janvier, T. A., Legends of the City of Mexico. Harper, I910.

Joyce, T. A., Central American and West Indian Archaeology. Putnam, I9i6.

-Mexican Archaeology. Putnam, I9r4.

- South American Archaeology. Putnam, I9I2.

Markham, Sir C. R., The Incas of Peru. (Lond.) Smith, Elder, I9Io. Maudslay, Anne Cary, A Glimpse at Guatemala. (Lond.), Murray, I899. Spence, Lewis, The Civilization of Ancient Mexico. Putnam, I912. -The Myths of Mexico and Peru. (Lond.) Harrap, I9r3.

Squier, E. G., Travel and Exploration in the Land of the Incas. Harper, I877.

Winsor, Justin, Narrative and Critical History of America. (8 vols.) Vol. I, Houghton Mifflin, I889.

3. The Era of Discovery and Exploration.

Abbott, W. C., Expansion of Europe. 2 vols. Holt, I9r8.

Bates, Lindon, Jr., The Path of the Conquistadores. Houghton Mifflin, rgr 2.

Bourne, E. G., Spain in America, 1450-1580. Harper, I906.

Chapman, C. E., The Founding of Spanish California. Macmillan, I916. Fiske, John, The Discovery of America. 2 vols. Houghton Mifflin, I895. Gilman, Arthur, Tales of the Pathfinders. (Bost.) Lothrop, I884. 
Helps, Sir Arthur, The Spanish Conquest in America. 4 vols. (N. Y.) Lane, I900-I904.

Lummis, C. F., The Spanish Pioneers. McClurg, I893.

MacNutt, F. A., Fernando Cortes and the Conquest of Mexico. 14851547. Putnam, 1909.

Markham, Sir C. R., The Conquest of New Granada. (Lond.) Smith, Elder. Oliveira Martins, J. P. (Abraham, J. J., and Reynolds, W. E., trans.), The Golden Age of Prince Henry the Navigator. (Lond.) Chapman \& Hall, I9I4.

Prescott, W. H., The Conquest of Mexico. 3 vols. Harper, 1843 . The Conquest of Peru. 2 vols. Harper, 1847.

Richman, I. B., The Spanish Conquerors. Yale Univ. Press. I9I8. Stephens, Kate, The Mastering of Mexico. Macmillan, r9ı6.

Young, Filson, Christopher Columbus and the New World of His Discovery. 2 vols. Lippincott, 1906.

\section{The Colonial Era.}

Bolton, H. E., The Spanish Borderlands. Yale Univ. Press, I921.

Bolton, H. E., and Marshall, T. M., The Colonization of North America, 1492-1783. Macmillan, r920.

Chapman, C. E., The Northwest Expansion of New Spain, $1687-1783$. Macmillan, r9r6.

Graham, R. B. Cunninghame, A Vanished Arcadia. (N. Y.) Heinemann, I90I.

Haring, C. H., The Buccaneers in the West Indies in the XVII Century. Dutton, rgro.

Ireland, Alleyne, Tropical Colonization. Macmillan, I899.

Keller, A. G., Colonization. Ginn, 1908.

Klein, Julius, The Mesta. A Study in-Spanish Economic History, 1273-1836. Harvard Univ. Press, I920 .

Latimer, Elizabeth W., Spain in the Nineteenth Century. (Chi.) McClurg, I897.

Lea, H. C., The Inquisition in the Spanish Dependencies. Macmillan. Lowery, Woodbury, The Spanish Settlements in the United States. 2 vols. Putnam, I9II.

Mitré Bartolomé, (Wm. Pilling, trans.), The Emancipation of South America. (Lond.) Chapman \& Hall, 1893.

Morris, H. C., History of Colonization. Macmillan, I904.

Moses, Bernard, The Establishment of Spanish Rule in America. 2 vols. Putnam, I898.

- South America on the Eve of Emancipation. Putnam, I908. 
Moses, Bernard, Spanish Dependencies in South America. 2 vols. Harper, I9r4.

Muir, Ramsay, The Expansion of Europe. Houghton Mifflin, I9r9. Payne, E. H., History of European Colonization. Macmillan, I889. Rodway, James, The West Indies and the Spanish Main. Putnam, r896. Roscher, W. G. F., The Spanish Colonial System. Holt, I904.

Watson, G. R., Spanish and Portuguese South America. 2 vols. London, I884.

Winsor, Justin, Narrative and Critical History of America. 8 vols. Houghton Mifflin, r889.

\section{Works on State and Sectional Development}

A. Histories of Individual Republics.

\section{Argentina.}

Hammerton, F. A., The Real Argentina. Dodd, Mead, I9I4.

Hirst, W. A., Argentina. Scribner, I9Io.

Koebel, W. H., Argentina, Past and Present. Dodd, Mead, r9ro. Modern Argentina. (Lond.) Griffiths, I907.

Martinez, A. B., and Lewandowski, M., The Argentine in the 2oth Century. (Lond.) Unwin, r915.

Mills, G. J., Argentina. Appleton, 19r5.

Pennington, A. S., The Argentine Republic. Stokes, I9ro.

Winter, N. O., Argentina and Her People of Today. Page, I9ro.

2. Bolivia.

Schurz, W. L., Bolivia, A Commercial and Industrial Handbook. (Wash.) Gov't Print. Off., r921.

Walle, Paul, Bolivia. Scribner, I9r4.

Wright, Marie H., Bolivia. (Phila.) Barrie, r907.

3. Brazil.

Bruce, G. J., Brazil and the Brazilians. Dodd, Mead, I9I4.

Buley, E. C., North Brazil. Appleton, I9I4.

-South Brazil. Appleton, rgr4.

Denis, P., Brazil. Scribner, Igrr.

Domville-Fife, C. W., The United States of Brazil. (Lond.) Griffiths, Igro.

Elliott, L. E., Brazil Today and Tomorrow. Macmillan, I918.

Oliveira Lima, Manuel de, Evolution of Brazil. Stanford Univ. Press, I9I4.

Winter, N. O., Brazil and Her People of Today. Page, rgro. 
4. Chile.

Elliott, G. F. S., Chile. Scribner, 1907.

Hancock, H. V., A History of Chile. (Chi.) Sergel, I893.

Koebel, W. H., Modern Chile. Macmillan, I9I4.

Maitland, F. J. G., Chile. (Lond.) Griffiths, I9I4.

Mansfield, R. E., Progressive Chile. (N. Y.) Meade, I9r3.

Mills, G. J., Chile. Appleton, I9I4.

Perez Canto, Julio, Chile: an Account of Its Wealth and Progress.

(Lond.) Routledge, I9I 2.

5. Colombia.

Eder, P. J., Colombia. Scribner, I913.

Levine, V., Colombia. Appleton, I9I4.

Petre, F. L., The Republic of Colombia. (Lond.) Stanford, 1906.

6. Costa Rica.

Calvo, Joaquin Bernardo, The Republic of Costa Rica. Rand, McNally, 1890 .

Gómez Villafranca, Roman, Costa Rica. 1908.

Guardia, R. F., History of the Discovery and Conquest of Costa Rica. Crowell, I9I3.

7. Cuba.

Forbes-Lindsay, C. H., Cuba and Her People of Today. Page, igı.

Quesada, Gonzalo de, Cuba. (Wash.) Gov't Print. Off., I905.

Robinson, A. G., Cuba, Old and New. Longmans, 1915.

Verrill, A. H., Cuba, Past and Present. Dodd, Mead, I9r4.

Wright, Irene A., Cuba. Macmillan, Igro.

8. Ecuador.

Enock, C. R., Ecuador. Scribner, I9I4.

9. Guatemala.

Brigham, W. T., Guatemala. Scribner, 1887.

Winter, N. O., Guatemala and Her People of Today. Page, Igog.

10. Haiti.

Leger, J. N., Haiti, Her History and Her Detractors. (N. Y.) Neale, 1907.

Prichard, Hesketh, Where Black Rules White. (Lond.) Smith, Elder, 1884.

St. John, Sir Spencer. Haiti, the Black Republic. (Lond.) Smith, Elder, 1884 . 


\section{I. Honduras.}

Neville, Edward (ed.), The Republic of Honduras. Dun's International Review.

Squier, E. G., Honduras, Descriptive, Historical, and Statistical. (Lond.) Trübner, 1870.

\section{I2. Mexico.}

Barron, C. W., The Mexican Problem. Houghton Mifflin, I9I7.

Bancroft, H. H., The History of Mexico. The Bancroft Co., I9I4.

Carson, W. E., Mexico, the Wonderland of the South. Macmillan, r9r4.

Enock, C. R., Mexico. Scribner, I909.

Fyfe, Hamilton, The Real Mexico. McBride, Nast, I9I4.

Hale, Susan, The Story of Mexico. Putnam, I9II.

MacHugh, R. J., Modern Mexico. Dodd, Mead, r9I4.

Martin, P. F., Mexico of the Twentieth Century. Dodd, Mead, I907. -

Morris, Charles. The Story of Mexico. Winston, I9I4.

Noll, A. H., A Short History of Mexico. McClurg, I8go.

Reed, John, Insurgent Mexico. Appleton, I9I4.

Trowbridge, E. J., Mexico, Today and Tomorrow. Macmillan, I9I9.

Winter, N. O., Mexico and Her People of Today. Page, I9ro.

\section{I3. Nicáragùa.}

Stout, P. F., Nicaragua, Past, Present and Future. (Phila.) Potter, I859.

\section{I4. Panama.}

Abbot, W. J., Panama and the Canal. Dodd, Mead, I9I4.

Bishop, Farnham, Panama, Past and Present. Century, I913.

Bunau-Varilla, Philippe, The Great Adventure of Panama. Doubleday, Page, I920.

Forbes-Lindsay, C. H., Panama and the Canal Today. Page, r9r3.

Gause, F. A., and Carr, C. C., The Story of Panama. Silver, Burdett, IgI 2.

\section{I5. Paraguay.}

Koebel, W. H., Paraguay. Scribner, I9r7.

Washburn, C. A., The History of Paraguay. (N. Y. ) Lee, Shepard \& Dillingham, r87r.

I6. Peru.

Enock, C. R., Peru. Scribner, 1908.

Markham, C. R., A History of Peru. Sergel, I892. 
Martin, P. F., Peru of the Twentieth Century. Longmans, I9Ir.

Vivian, E. C., Peru. Appleton, Igr4.

I7. Salvador.

Martin, P. F., Salvador of the Twentieth Century. Longmans, IgIr.

I8. Santo Domingo.

Hazard, Samuel, Santo Domingo, Past and Present. Harper, 1873

Schonrich, Otto, Santo Domingo. Macmillan, Igr8.

Stoddard, T. L., The French Revolution in San Domingo. Houghton Mifflin, I9I4.

Verrill, A. H., Porto Rico, Past and Present, and Santo Domingo. Dodd, Mead, rgi4.

19. Uruguay.

Domville-Fife, C. W., A Chapter in the United States of Brasil. (N. Y.) Pott, I9Ir.

Koebel, W. H., Uruguay. Scribner, I9I5.

20. Venezuela.

Dalton, L. V., Venezuela. Scribner, I912.

Goiticoa, N. Veloz, Venezuela, (Wash.) Gov't Print. Off., I904.

B. Histories of Sectional Development.

Aspinwall, A. E., The British West Indies. Little, Brown, I9r2.

Bancroft, H. H., The History of Central America. 3 vols. (S. Fran.) Bancroft, I883-r887.

Domville-Fife, C. W., Guatemala and the States of Central America. (Lond.) Griffiths, I9I3.

Enock, C. R., The Tropics. Scribner, 19r5.

Eves, C. W., The West Indies. (Lond.) Low, r889.

Hill, R. F., Cuba and Porto Rico, with Other Islands. Century, I8g8.

Koebel, W. H., Central America. Scribner, I9r 7.

- South America. Scribner, I9Ig.

Munro, D. C., The Five Republics of Central America. Oxford Univ. Press, I9I8.

Palmer, Frederick, Central America and Its Problems. (Lond.) Moffat, Yard, rigro.

Porter, R. P., The Ten Republics. Rand, McNally, I9r1.

Rodway, James, Guiana: British, French, and Dutch. Scribner, 1912. Ross, Gordon, Argentina and Uruguay. Macmillan, Igr6.

Rowe, L. S., The United States and Porto Rico. Longmans, 1904. 
Scruggs, W. L., The Colombian and Venezuelan Republics. Little, Brown, 1900.

Squier, E. G., The States of Central America. Harper, 1858.

Verrill, A. H., The Book of the West Indies. Dutton, I9I7.

-The Colombian and Venezuelan Republics. Dutton, I9ro. -Costa Rica, Past and Present, and Santo Domingo. Dodd, Mead, I9I4.

Westergaard, Waldemar, The Danish West Indies. Macmillan, I9I7.

\section{Special Phases of Latin-American History}

\section{A. Political and Diplomatic History.}

I. United States Diplomacy and National Policy.

Abbott, J. F., Japanese Expansion and American Policies. Macmillan, . I9I6.

Barcom, C. W., The Mexican Problem. Houghton Mifflin, I917.

Bonsal, Stephen, The American Mediterranean. Moffat, Yard, I9I2.

Channing, Edward, History of the United States. 5 vols. Macmillan, I905-I92I.

Coolidge, A. C., The United States as a World Power. Macmillan, I908.

Crichfield, G. W., American Supremacy. 2 vols. Brentano, I908. Fish, C. R., American Diplomacy. Holt, I9i6.

Foster, J. W., A Century of American Diplomacy. Houghton Mifflin, I900.

Fullerton, W. M., Problems of Power. Scribner, I9I5.

Goebel, J. L., The Recognition Policy of the United States. Columbia University Studies, I9I5.

Henderson, J. B., Jr., American Diplomatic Questions. Macmillan, I90I. Hodges, H. G., The Doctrine of Intervention. (Princeton) The Banner Press, I915.

Latané, J. H., America as a World Power, I897-19I7. Harper, I9I7. McLaughlin, A. C., America and Britain. Dutton, I918.

Moore, J. B., Principles of American Diplomacy. Harper, I9I8.

Ogg, F. A., National Progress, I907-1917. Harper, I917.

Powers, H. H., America Among the Nations. Macmillan, I9r 7.

Roosevelt, Theodore, Fear God and Take Your Own Part. Doran, I916.

Schuyler, Eugene, American Diplomacy. Scribner, 1895 .

Weyl, W. E., American World Policies. Macmillan, I917.

Williams, Mary W., Anglo-American Isthmian Diplomacy. (Balto.)

Lord Press, Igr6. 
2. Inter-State and Inter-American Relations.

Blakeslee, G. H. (ed.), Mexico and the Caribbean. (Clark University Addresses). Stechert, 1920.

Borchard, Stephen, The American Mediterranean. Moffat, Yard, I9г2.

Calderon-Cousino, Adolfo, Short Diplomatic History of Chilean-Peruvian Relations, $1819-1879$. (Santiago de Chile) Impr. Universitaria, 1920.

Chadwick, Admiral F. E., The Relations of the United States and Spain. 3 vols. Scribner, I909-19II.

Goldsmith, P. H. (trans.), South American Opinions on the War. Carnegie End. for Int. Con., I9I7.

Jones, C. L., Caribbean Interests of the United States. Appleton, I9I6. Kirkpatrick, F. A., South America and the War. Cambridge Univ. Press, I9I8.

Latané, J. H., Diplomatic Rclations of the United States and Spanish America. Johns Hopkins Press, I900.

The United States and Latin America. Doubleday, Page, 1920.

Mansfield, E. C., History of the War with Mexico. N. Y., I849.

Markham, Sir C. R., The War between Peru and Chile, I879-I882. (Lond.) Low, Marston, I882.

Maurtua, Victor M., The Question of the Pacific. Harper, I9I9.

Reyes, Rafael, The Two Americas. Stokes, Igr4.

Robertson, W. S., The Beginnings of Spanish-American Diplomacy. Holt, I9I0.

Rocuant, E., (H. E. Swinglehurst, trans.), The Neutrality of Chile. (Valparaiso) Soc. imprenta y litografía universo, 1919.

Salas-Edwards, Ricardo, The Liquidation of the War on the Pacific. (Lond.), Dunlop, Igoo.

Scruggs, W. O., Filibusters and Financiers. Macmillan, I916.

Smith, J. H., The War with Mexico, I846-1848. Macmillan, I9I9. Stevenson, N. W., Texas and the Mexican War. Yale Univ. Press, 1918. Verrill, A. H., Getting Together with Latin America. Dutton, I9I8.

3. The Monroe Doctrine and Pan-Americanism.

Barrett, John, Pan-America and Pan-Americanism. Harper, 19I5. Bigelow, John, American Policy: the Western Hemisphere in Its Relation to the Eastern. Scribner, I9I4.

Bingham, Hiram, The Monroe Doctrine, an Obsolete Shibboleth. Yale Univ. Press, I9I 3.

Blakeslee, G. H. (ed.), Latin America; (Clark University Addresses). Stechert, ror4. 
Chandler, C. L., Inter-American Acquaintances. (Sewanee, Tenn.) University Press, I9I 7.

Edgington, T. B., The Monroe Doctrine. Little, Brown, I905.

Hall, A. B., The Monroe Doctrine and the Great War. McClurg, I920.

Hart, A. B., The Monroe Doctrine, an Interpretation. Little, Brown, I9I 7 .

Hull, W. I., The Monroe Doctrine, National or International? Putnam, I9I5.

Lockey, J. B., Pan-Americanism; Its Beginnings. Macmillan, I920.

MacCorkle, W. A., The Monroe Doctrine in Its Relation to the Republic of Haiti. (N. Y.) Neale, I9I5.

Paxson, F. L., The Independence of the South American Republics. (Phila.) Ferris and Leach, I903.

Reddaway, W. F., The Monroe Doctrine. Cambridge Univ. Press, I898. Root, Elihu, Miscellaneous Addresses. Harvard Univ. Press, I9r7. Tucker, G. F., The Monroe Doctrine: Its Origin and Growth. (Bost.) Reed, I885.

Usher, R. G., Pan-Americanism. Century, I915.

B. Economic Conditions, Problems, and Development.

I. Miscellaneous Works Touching Latin-American Trade.

Barrett, John, Latin America, the Land of Opportunity. International Bureau of American Republics, I909.

Blakeslee, G. H. (ed.), Latin America. (Clark Univ. Addresses). Stechert, I9I4.

Brooks, H. K., Foreign Exchange. (N. Y.) Delbridge, 1906.

Cattell, E. J., and Others (eds.), Foreign Commercial Guide: South America. Phila. Commercial Museum, I906.

Cooper, C. J., Understanding South America. Doran, I909.

Cosby, T., Latin-American Monetary and Exchange Conditions. (N. Y.) National City Bank.

Koebel, W. H., The South Americans. Dodd, Mead, I9I5.

Miller, B. L., and Singewald, J. T., The Mineral Deposits of South America. McGraw, Hill, r9r9.

Pearson, H. C., The Rubber Country of the Amazon. (N. Y.) India Rubber World, I9гі.

Savay, Norbert, Principles of Foreign Trade. (N. Y.) Ronald Press, Igrg.

Verrill, A. H., South and Central American Trade Conditions. Dodd, Mead, rgrg. 
2. United States Commercial Relations with LatinAmerica.

Aughinbaugh, W. E., Selling Latin America. Small, Maynard, 1920. Day, Clive, History of Commerce. Macmillan, 1904.

Filsinger, E. B., Exporting to Latin America. Appleton, I919.

-Trading with Latin America. Irving National Bank, I918.

Hough, Olney, Practical Exporting. Johnston Export Pub. Co., I918.

O'Malley, Frank, Our South American Trade and Its Financing. National City Bank, I920.

Pepper, C. M., American Foreign Trade. Century, Igrg.

Snyder, G. S., Selling in Foreign Markets.

Trade Thoughts of the Two A mericas. (N. Y.) Irving National Bank, I9I9.

Vedder, G. C., American Methods in Foreign Trade. (N. Y.) McGraw, Hill, rgrg.

Webster, W. C., General History of Commerce. Ginn, I903.

\section{Illustrative and Supplementary Materials.}

A. Primary Sources and Documents.

Brazil, Ministry for Foreign Affairs, The Brazilian Green Book, I9141917. (Lond.) Unwin, 1918.

Dodd, W. F., Modern Constitutions. 2 vols. Univ. of Chicago Press, I909.

Foreign Relations of the United States. (Wash.) Gov't Printing Office, annually.

Hicks, F. C., The New World Order (Appendices). Doubleday, Page, 1920. Juan y Santacilia, Jorge, and Ulloa, Antonio de, $A$ Voyage to South America. (Lond.), Davis \& Reymers, 1760.

Major, R. H. (trans.), Select Letters of Christopher Columbus. (Lond.) The Hakluyt Society, I870.

Malloy, W. M., Treaties, Conventions, etc., between the United States and Other Powers. Washington, I910.

Maudslay, A. P. (trans.), The True History of the Conquest of New Spain, by Bernal Diaz del Castillo. (Lond.) The Hakluyt Society, vol. V, I916.

Moses, Bernard (trans.), Constitution of the Republic of Colombia. (Washington) Gov't Printing Office, 1903.

Robinson, W. D., Memoirs of the Mexican Revolution. (Phila.) The Author, 1820 .

Rodriquez, J. T., American Constitutions. 2 vols. (Wash.) Gov't Printing Office, I906-I907. 
B. Biography.

Beazley, C. R., Prince Henry the Navigator. Putnam, 1895.

Burke, U. R., A Life of Benito Juarez, Constitutional President of Mexico. (Lond.) Remington, I894.

Gilman, D. C., James Monroe. Houghton Mifflin, rgoo.

Guillemard, F. H. H., The Life of Ferdinand Magellan. (Lond.) Philip, I89o.

Hall, Frederic, Life of Maximilian I. New York, 1868.

Jayne, K. G., Vasco da Gama and His Successors. 1460-1580. (Lond.) Methuen, I9Io.

Larrazabal, Felipe, The Life of Simon Bolivar. (N. Y.) Jenkins, 1875 . MacNutt, F. A., Bartholomew de las Casas. Putnam, I909.

Major, R. H., Life of Prince Henry of Portugal. (Lond.) Asher, 1868. Mitré, Gen. Don Bartolomé, History of San Martin. (Lond.) Chapman \& Hall, 1889 .

Noll, A. H., and McMahon, A. P., The Life and Times of Miguel Hidalgo y Cosilla. McClurg, I9ıo.

Petre, F. L., Simon Bolivar, "El Libertador." (N. Y.) Lane, I9ıо. Robertson, W. S., Rise of the Spanish American Republics as Told in the Lives of Their Liberators. Appleton, 1918.

Thacher, J. B., Christopher Columbus. 3 vols. (N. Y.) 1903-1904.

Thayer, H. R., Life of John Hay. 2 vols. Houghton Mifflin, I915.

C. Latin-American Literature.

I. Historical Novels and Prose Literature.

Aranha, Joseph Eraca, Canaan. (Bost.) Four Seas Co., I9I4.

Blasco Ibañez, Vicente, The Four Horsemen of the A pocalypse. Dutton, 1918.

- The Shadow of the Cathedral. Dutton, Igrg.

Blest Gana, Albert, Martin Rivas. Knopf, 1910.

Coester, Alfred, The Literary History of South America. Macmillan, I9I7.

Isaacs, Jorge, Maria. Macmillan, I921.

Marmol, José, Amalia. Macmillan, I9Ig.

Starr, Frederick, Readings from Modern Mexican Authors. (Chi.) Open Court, I904.

Turrell, C. A., Spanish-American Short Stories. Macmillan, I920.

2. Latin-American Poetry and Drama.

Calderon, Fernando, Eight Dramas. (Edward Fitzgerald, trans.) London, I906. 
Bierstadt, Albert (ed.), Thrce Plays from Argentina. (N. Y.) Duffield, I920.

Hills, E. C., and Morley, S. G., Modern Spanish Lyrics. Holt, I9r3.

D. Periodicals and Current Publications.

I. Brief List of Papers and Periodicals, Dealing with Latin America.

American Exporter. Monthly. Johnston Export Publishing Co., N. Y.

American Historical Review. Quarterly. Organ of the American Historical Association. Published by The Macmillan Co., N. Y. American Journal of International Law: Supplement. Quarterly Organ of the American Society of International Law. Published by Baker, Voorhis \& Co., N. Y.

American Political Science Review. Quarterly. Organ of the American Political Science Association, Baltimore, Md.

Americas (The). Monthly. Foreign Department, National City Bank, N. Y.

Annals of the American Academy of Political and Social Science. Bimonthly. Issued by the American Academy of Political and Social Science, Concord, N. H.

Bulletin of the Pan-American Union. Monthly. Issued by the PanAmerican Union, Washington, D. C.

Commerce Reports. Daily. Issued by the Department of Commerce, Government Printing Office, Washington, D. C.

Commercial America. Monthly. Philadelphia Commercial Museum, Philadelphia, Pa.

Hispanic American Historical Review. Quarterly. Published for the Board of Directors of The Review by Williams and Wilkins Co., Baltimore, Md.

Inter-America. A monthly magazine. Doubleday, Page \& Co., Garden City, N. Y.

International Conciliation. Monthly Bulletin of the American Association for International Conciliation, N. Y.

Journal of International Relations. (Journal of Race Development.) Quarterly. Worcester, Mass.

League of Nations. Bi-monthly bulletin. World Peace Foundation, Boston.

London Times. (South American Supplement.) Daily.

New York Commercial. Daily. 
Pan-American Magazine. Monthly. The Pan-American Magazine, Inc., N. Y.

Political Science Quarterly. Published tri-monthly by the Academy of Political Science, Columbia University, N.Y.

Quarterly Journal of Economics. Published tri-monthly by the Harvard University Press, Cambridge, Mass.

South American (The). Monthly. Issued by the South American Publishing Co., Inc., N. Y.

2. Yearbooks, Commercial Guides, et:.

American Yearbook (The). Appleton \& Co., N. Y.

Annual Report of the Council of the Corporation of Foreign Bond-holders. London.

Bureau of Foreign and Domestic Commerce, Trade Directories. Government Printing Office, Washington, D. C.

Cattell, E. J., and Others (eds.), Foreign Commercial Guide: South America. Philadelphia Commercial Museum, Philadelphia, Pa., I906. Directory of Latin America. Universal Publicity Co., N. Y. Exporters' Encyclopedia. Exporters' Encyclopedia Co., N. Y. Export Trade Directory. The American Exporter, N.Y. National Foreign Trade Conventions, Accounts of Proceedings. Issued for the years 1914-1919 by the Secretary of the Convention, N. Y. Pan-American Direciory. Pan-American Directory Corporation, N. Y. Proceedings of the International Trade Conference. National Association of Manufacturers, N. Y., I9I5.

Reports of the Pan-American Commercial Conferences. Published for the years I9II, 1919. Government Printing Office, Washington, D. C., I91 2, r920.

South American Year Book. L. Cassier \& Co., London.

Wilcox, M. and Rines, G. E. (eds.), Encyclopedia of Latin America. The Encyclopedia Americana Corp., I9r 7.

E. Further Bibliographical Suggestions.

I. General Phases of Latin-American Development.

Cambridge Modern History, vol. I, pp. 693-699; vol. X, pp. 812-826; vol. XII, pp. 949-953.

Cundall, F., Bibliography of the West Indies (Excluding Jamaica). Kingston, I909.

Goldsmith, F. H., Brief Bibliography of Books Relating to Latin-American Republics. Macmillan, I9I5. 
Jones, C. K, Hispanic American Bibliographies. Hispanic American Historical Review, vols. III, IV.

Koebel, J. H., British Exploits in South America, pp. 555-569.

[Also see Indexes to articles in current publications: e.g., "Poole's," "Reader's Guide," etc.]

2. United States Political Relations with Latin America.

Hart, A. B., The Monroe Doctrine, An Interpretation, pp. 405-42I.

Haase, A. R., Index to United States Documents Relating to Foreign Affairs. Carnegie Institute, I9I4.

Jones, C. L., Caribbean Interests of the United States, pp. 353-358.

Meyer, H. H. B., List of References on the Monroe Dctrine. (Wash.) Gov't Print. Off., I9I9.

3. United States Commercial and Business Relations with Latin America.

Filsinger, E. B., Exporting to Latin America, pp. 465-498.

Shuey, H. S., Bibliography of Foreign Trade Publications. (S. Fran.) Bosch, igi 8 .

United States Department of Commerce, Bureau of Foreign and Domestic Commerce, Catalogue of Bureau Publications. (Wash.) Gov't Print. Off., I920. 


\section{LIST OF OUTLINE MAPS \\ AND SUGGESTIONS FOR USE}

\section{The European Background of Hispanic-American}

History, facing p. 28.

To show: ${ }^{1}$

Racial elements in the Iberian peninsula

Political evolution of Spain and Portugal

Geographic, economic, and ethnographic conditions

Principal Hispanic ports; etc.

Map references: ${ }^{2}$

Bolton and Marshall, Colonization of North America, p. I5.

Cheyney, Europcan Background of American History, p. 80.

Dow, Atlas of European History, pp. 2, 4, 5, 6, 8, 9, I5, etc.

Grant, Passing of the Great Race, pp. 266-272.

Muir, Hammond's New Historical Atlas, pp. 1-4, 6-9, 18-т9.

Putzger, Historischer Schul-Atlas, pp. 2, 3, 9, I2, I3, I6, I7, 20.

Shepherd, IIistorical Atlas, pp. 2, 34, 38, 45, 54, 82, 83 .

II. The Field of Discovery and Conquest, facing p. 34 .

To show:

Native peoples in the New World

Early voyages of discovery

${ }^{1}$ These and subsequent suggestions are given to indicate but a few of the several ways in which the accompanying outline maps may be employed. The maps may be prepared to show any one of the features here proposed, or several of them, or other phases of Hispanic-American development not mentioned.

${ }^{2}$ It is practically impossible to give a complete list of maps suitable for study or use in preparing the outline maps according to specifications. Many of the best maps for special purposes are to be found in periodicals and bulletins. Those cited here are more or less general in character, and will often have to be supplemented from other sources. 
Papal Line of Demarcation and Treaty of Torredesillas

First Spanish settlements in America

The conquest of Mexico and Peru; etc.

\section{Map references:}

Bolton and Marshall, Colonization of North America, pp. 6, 9, 18, 30, 143, etc.

Bourne, Spain in America, p. 35.

Dow, Atlas of European History, p. I6.

Muir, Hammond's New Historical Atlas, pp. 46-47.

Koebel, South America, p. 9.

Shepherd, Historical Atlas, pp. 105-I II.

\section{Colonial Expansion in America, facing p. 44.}

To show:

Establishment of the continental colonies

Hispanic colonial administrative districts

Areas of missionary (Jesuit) activity

Hispanic possessions at their greatest extent

Principal centers of colonial population; etc.

\section{Map references:}

Bolton and Marshall, Colonization of North America, pp. 63, 68, 250, $390,399$.

Bourne, Spain in America, p. I35.

Dawson, The South American Republics, I, p. 5I 2.

Muir, Hammond's New Historical Atlas, pp. 47-50, 53, 56 .

Putzger, Historischer Schul-Atlas, pp. 38-39.

Shepherd, Historical Atlas, pp. I 28, I36, 214-215.

Sweet, History of Latin America, pp. 82, г36.

\section{The Revolutionary Period in South America,} facing p. $5^{2}$.

To show:

Fields of filibustering activity

Important fleet movements

Revolutionary campaigns and decisive battles

Progress toward independence; etc. 
Map references:

Dawson, The South American Republics, II, p. 489 .

Dow, Atlas, of European History, p. 3r.

Muir, Hammond's New Historical Atlas, pp. 5 I, ${ }_{5} 8$.

Sweet, History of Latin America, pp. 156, 170.

\section{The American Mediterranean, facing p. 68.}

To show:

The present and proposed canal routes

Economic conditions in the northern republics

United States' "protectorates"

European colonial possessions

Routes of trade and commerce; etc.

\section{Map references:}

Bowman, The New World, p. 560.

Hart, The Monroe Doctrine, frontispiece.

Jones, Caribbean Interests of the United States.

Latané, The United States and Latin America, p. 262.

Muir, Hammond's New Historical Atlas, p. 53.

National Geographic Magazine, xxxiv, p. 402; xli, p. 221.

Shepherd, Historical Atlas, pp. 181, 187, 201, 213.

Sweet, History of Latin America, pp. 170, 243, 245, 250, $25 \mathrm{I}$.

\section{vi. Hispanic-American Political Development, facing}

p. 78 .

To show:

The Monroe Doctrine

Types of Latin-American government

Tendencies toward disintegration or consolidation

Boundary controversies and adjustments

Inter-state and foreign wars; etc.

Map references:

Bowman, The New World, pp. 570, 572, 574, 578 .

Akers, History of South America, pp. 576, end of vol.

Aughinbaugh, Selling Latin America, frontispiece.

Bryce, South America: Observations and Impressions, appendix.

Bullard, Panama, p. 66. 
Hart, The Monroe Doctrine; an Interpretation, frontispiece.

Muir, Hammond's New Historical Atlas, p. $5^{2}$.

National Geographic Magazine, xl, p. 238.

Shepherd, Historical Atlas, pp. 201-203, 213.

VII. Economic Conditions in South America, facing p. 92.

To show:

Geographical and climatic conditions

Natural resources: minerals, forests, water power

Areas of animal and vegetable production

Manufacturing industries

Principal ports, lines of navigation; etc.

\section{Map references:}

Garcia-Calderon, Latin America, p. 4 or.

Koebel, South America, p. 292.

Muir, Hammond's New Historical Atlas, p. 58.

National Geographic Magazine, xl, p. 238.

Porter, The Ten Republics, pp. IOI, II3, I57, I85, 207, 247, 264.

Shepherd, Historical Atlas, pp. I79-182.

Sweet, History of Latin America, pp. 22, 240, 243-245.

\section{ViII. Pan-American Relations, facing p. IO4.}

To show:

The Panama Canal and its use

The proposed Pan-American railway

Principal highways and railroads of Latin America

Attitude of Latin America toward the Great War; etc.

Map references:

Aughinbaugh, Selling Latin America, pp. 138, 168.

Bryce, South America, appendix.

Bullard, Panama, pp. 66, 460.

Garcia-Calderon, Latin America, p. $40 \mathrm{I}$.

Kirkpatrick, South America and the War.

National Geographic Magazine, xxxiv, p. 402; xxxvi, p. 194; xxxviii, pp. 5, 489; xl, p. 238.

Shepherd, Historical Atlas, p. 216.

Sweet, History of Latin America, pp. 190, 248, 250, $25 \mathrm{I}$. 


\section{THE COLONIAL ERA OF LATIN-AMERICAN HISTORY}

\section{A. THE EUROPEAN BACKGROUND}

I. Spanish and Portuguese Origins

a. The Racial Basis of Iberian History.

(I) The Formative Period.

(a) Physical Characteristics of the Peninsula.

i. Its size and position.

ii. Topography and climate: their influence.

(b) The Early Inhabitants of Spain.

i. Nature of the primitive Celto-Iberians.

ii. Extent of Carthaginian and Roman colonization.

iii. Spain "more Roman than Rome."

iv. Permanent effects of Roman domination.

(2) Later Racial and Cultural Elements.

(a) The Germanic Invasions.

i. Successive waves of Teutonic barbarians.

ii. Culture of the Visigothic Kingdom.

(b) The Mohammedan Régime.

i. Character of the Moslem conquest.

ii. Survival of Christian centers of resistance.

iii. Development of Moorish culture and institutions.

(c) Characteristics of the Conquering Race.

i. Psychological traits: African fanaticism.

ii. Individualism and its aspects.

BRIEF REFERENCES:

Akers, History of South America, pp. 3=4.

Chapman, A History of Spain, pp. 1-52, 202-209.

Garcia-Calderon, Latin America: Its Rise and Progress, pp. 29-43.

Grant, Passing of the Great Race, pp. 29-43, 53, 192-193.

Sweet, $A$ History of Latin America, pp. 7-15. 


\section{Detailed Accounts:}

Hale, Spain, chs. i-xiv.

Hume, The Spanish People, chs. i-iii.

Lane-Poole, The Moors in Spain, chs. i-x.

Stephens, The Story of Portugal, chs. i-v.

Additional References:

Boucher, Spain under the Roman Empire.

Busk, History of Spain and Portugal.

Helmolt, History of the World, vol. iv.

Lea, The Moriscos of Spain.

Merriman, Rise of the Spanish Empire, vol. i.

Ripley, Races of Europe.

Sergi, The Mediterranean Race.

b. Rise of the Spanish Kingdom.

(I) The Christian Reconquest of the Peninsula.

(a) The Creation of Christian Kingdoms.

i. Gradual recovery of the peninsula.

ii. Final expulsion of the Moors.

iii. Remaining veneer of Moorish blood and culture.

(b) Development of the Christian States.

i. Origin of Leon.

ii. Rise of Castile, Aragon, Portugal.

iii. Existence of smaller feudal states.

(2) The Union of Spanish Principalities.

(a) Feudal Conditions in the Peninsula.

i. Prevalence of anarchy.

ii. Absorption of the smaller states.

iii. Merging of Castile and Aragon.

iv. Addition of other territories.

(b) Political Institutions in Early Spain.

i. Appearance of liberal government: the cortes.

ii. Growth of despotism under Ferdinand.

iii. Later effects on Spain of America's wealth. 


\section{BRIEF REFERENCES:}

Bolton and Marshall, The Colonization of North America, 1492-1783, pp. I3-16.

Bourne, Spain in America, pp. 3-8.

Chapman, History of Spain, pp. 38-42, 67-83.

Keller, Colonization, pp. I68-172.

Sweet, History of Latin America, pp. 15-17.

\section{LONGER ACCOUNTS:}

Cheyney, Europcan Background of American History, pp. 79-104.

Hale, Spain, chs. xv-xx.

Hume, Spain, pp. I-30.

Hume, The Spanish People, chs. iv-viii.

Lane-Poole, The Moors in Spain, chs. xi-xiv.

\section{ADDITIONAL REFERENCES:}

Helmolt, History of the World, vol. iv.

Oliveira Martins, The Golden Age of Prince Henry the Navigator.

Oman, The Dark Ages.

Scott, The Moorish Empire in Europe.

Watts, The Christian Recovery of Spain.

c. Hispanic Life and Institutions.

(I) Religious and Political Organization.

(a) The Ecclesiastical System.

i. Relations of the Papacy and Spain: the Moors.

ii. The Prevalence of religious orders: The Inquisition.

iii. Church influence on autocratic government.

(b) The Growth of Towns.

i. Origin of Iberian towns.

ii. The several factors in their growth.

iii. Relation of town and national government.

(c) Nature of the Legal and Administrative Systems.

i. Preservation of the Visigothic code.

ii. Development of judicial procedure.

iii. Systems of taxation. 
(2) Economic and Social Conditions.

(a) Iberian Industry and Commerce.

i. History of agriculture in the peninsula.

ii. Effects of the Moorish wars.

iii. Nature and extent of industry.

iv. The basis of social gradations.

(b) Types of Hispanic Culture.

i. Contributions of the Jews and Mohammedans.

ii. Origin and nature of Latin dialects.

iii. Beginnings of national literature.

iv. Variety in Spanish 'life and character.

\section{General Accounts:}

Abbott, Expansion of Europe, vol. i, pp. I13, I23-128.

Akers, History of South America, pp. 4-6.

Cheyney, European Background of American History, pp. 96-гог.

Garcia-Calderon, Latin America, pp. 4I-43.

Hume, Spain, pp. 15-18.

Hume, The Spanish People, pp. 39-41, 47-52, 64-66, 86-90, 277-281.

Johnson, Europe in the Sixteenth Century, pp. 96-гог.

Further READING:

Lane-Poole, The Moors in Spain.

Lea, The Inquisition in Spain, vol. i.

Lea, The Moriscos of Spain.

Merriman, Rise of the Spanish Empire., vol. i.

Prescott, Ferdinand and Isabella.

Schaff, History of the Christian Church.

Walton, The Civil Law in Spain and Spanish America.

2. BAsis of the Expansion of Europe

a. Forces and Factors in Colonial Expansion.

(I) The Intellectual Awakening in Europe.

(a) Causes and Nature of the Renaissance.

i. Origin and spread of the movement.

ii. Commercial results of the Crusades.

iii. Rise of towns: increasing wealth. 
(b) Effects of the Renaissance Movement.

i. Decline of medieval ignorance and superstition.

ii. Spread of the scientific spirit.

iii. New theories concerning the earth.

(2) The Commercial Revolution.

(a) Effects of the Renaissance Spirit.

i. Improvements in shipbuilding.

ii. Development of navigating instruments.

iii. Influence of the printing press.

(b) Development of Commerce and Industry.

i. Decline of trade with the Orient.

ii. Growth of new markets and trade demands.

iii. Opening of new fields of commerce.

(c) Immediate Factors Coöperating in the Discovery of America.

i. The spirit of investigation.

ii. Demand for new sources of supply.

iii. Personal efforts of European monarchs.

BRIEF REFERENCES:

Akers, Soulh America, pp. 3-6.

Bolton and Marshall, Colonization of North America, pp. I-4.

Bourne, Spain in America, pp. 3-8.

Cambridge Modern History, vol. i, pp. 7-10.

Keller, Colonization, pp. 79-85, 168-172.

Moses, Establishment of Spanish Rule in America, pp. I-I6.

Morris, History of Colonization, pp. 230-243.

LONGER ACCOUNTS:

Abbott, Expansion of Europe, vol. i, pp. I-8I.

Cheyney, European Background, pp. 3-40.

Hayes, Political and Social History of Modern Europe, vol. i, pp. 27-62.

Hulme, Renaissance and Reformation, pp. 3-175.

Payne, European Colonies, pp. 37-5.3. 
b. Widening of the European Horizon.

(I) The Services of Portugal.

(a) Condition of Portugal in the Fifteenth Century.

i. Extent of national development.

ii. Nature of her political institutions.

iii. Character of Portuguese society.

iv. Influence of position and climate.

(b) Portuguese Explorations.

i. Work of Prince Henry, "the Navigator."

ii. Survey of the African coast.

iii. Discovery of a water route to India.

iv. Effect on Portuguese interest in America.

(2) The Prelude to Spanish Discoveries.

(a) Spain in 1492.

i. Recent national unification.

ii. End of the Moorish wars.

iii. Need of outlets for national energy.

(b) Early Career of Christopher Columbus.

i. His birthplace: early experiences.

ii. Influence of Marco Polo.

iii. Columbus' attempts to obtain royal support.

iv. His final commission by Spain.

BRIEF REFERENCES:

Bolton and Marshall, Colonization of North America, pp. 4-8.

Jones, Caribbean Interests, pp. I-4.

Keller, Colonization, pp. I $72^{-1} 74$.

Sweet, $A$ History of Latin A merica, pp. 32-35.

LONGER ACCOUNTS:

Abbott, Expansion of Europe, vol. i, pp. 82-96.

Bourne, Spain in America, pp. 8-19.

Cambridge Modern History, vol. i, pp. 10-22.

Cheyney, European Background, pp. 4I-79.

Hulme, Renaissance and Reformation, pp. 175-188.

Stephens, The Story of Portugal, pp. ז40-157. 


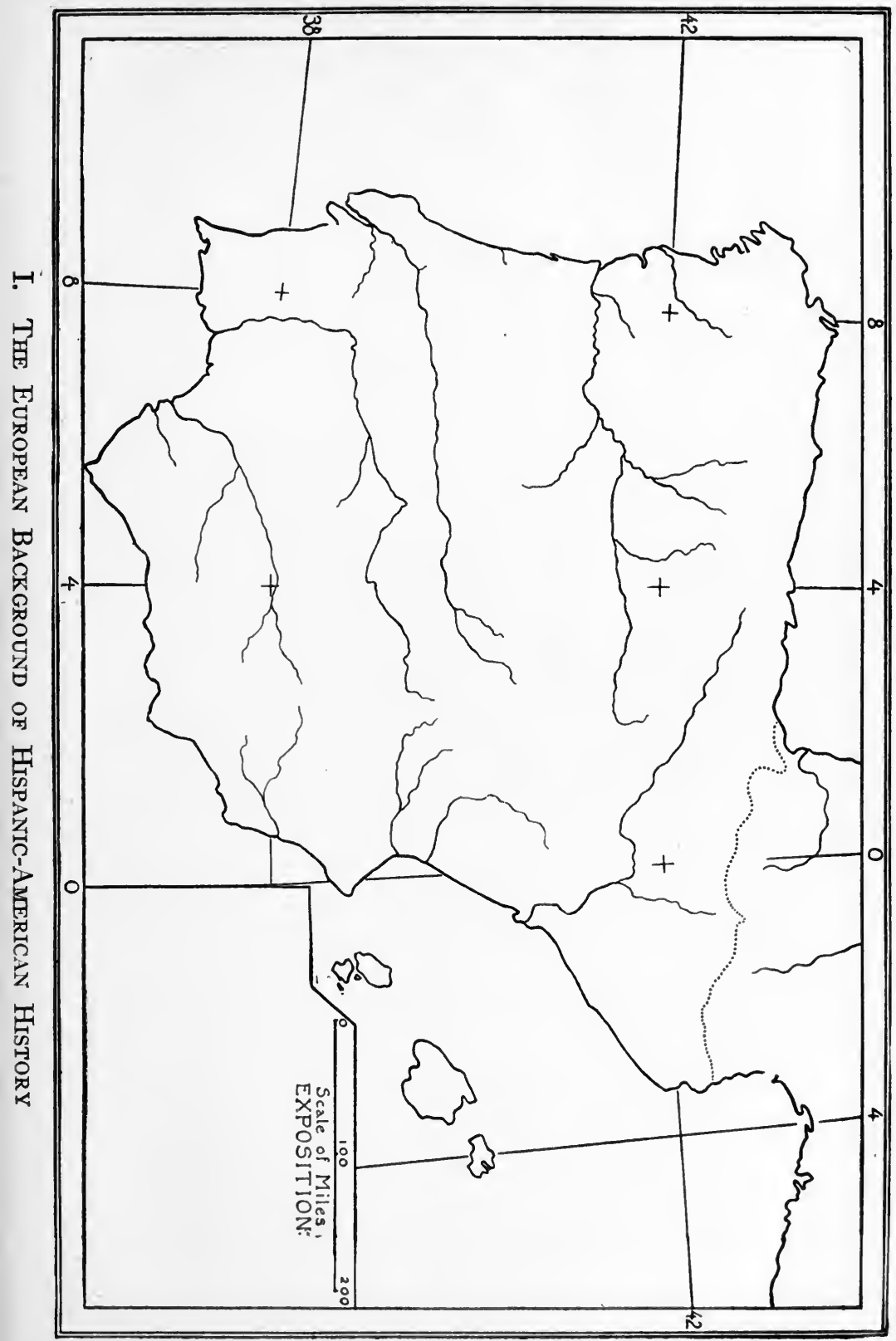


Furtiner READING:

Jayne, Vasco da Gama and His Successors.

Martins, The Golden Age of Prince Henry the Navigator.

Morris, History of Colonization.

Payne, European Colonies.

\section{B. THE ERA OF DISCOVERY AND CONQUEST \\ I. The Unveiling of the New World}

a. The Finding of Western Lands.

(I) Early Stages of Discovery.

(a) Columbus' First Voyage.

i. Trials of the voyage: "Land!"

ii. The first attempt at colonization.

iii. The triumphal return of the Pathfinder.

iv. European ideas and activities revolutionized.

(b) Supplementary Discoveries.

i. Later explorations of Columbus.

ii. Magellan's epoch-making voyage.

iii. Cabral and the Portuguese claim to Brazil.

(c) The Naming of the Western World.

i. Supposed voyages of Americus Vespuccius.

ii. Spread and influence of his writings.

(2) Defining of the New World.

(a) Partition of Colonial Realms.

i. The first papal Line of Demarcation, 1493 .

ii. The Treaty of Tordesillas, I494.

(b) Supplementary Discoveries and Exploration.

i. The Spaniards in North America.

ii. Discovery of the South Sea.

iii. The charting of coast lines.

BRIEF REFERENCES:

Abbott, Expansion of Europe, vol i, pp. 96-108, 148-151, 200-221.

Bolton and Marshall, Colonization of North America, pp. 8-12, 23-29.

Bryce, South A merica:Observations and Impressions, pp. 1-2,284-286, 366 . 
Jones, Caribbean Intcrests, pp. 4-I9.

Keller, Colonization, pp. I74-176.

Koebel, South America, pp. 14-25.

Porter, The Ten Republics, pp. I-4.

Shepherd, Latin America, pp. 9-10.

Sweet, History of Latin America, pp. 35-45.

\section{DetaIled Accounts:}

Bourne, Spain in America, pp. 20-132.

$\checkmark$ Bullard, Panama, pp. I32-I49.

Cambridgc Modern History, vol. i, pp. 22-36.

Further READING:

Bancroft, Central America, vol. i.

Fiske, Discovery of America, vol i.

Guillemard, Magellan.

Thacher, Columbus.

Winsor, Christopher Columbus.

b. Character of the New World.

(r) Physical Characteristics of Latin America.

(a) General Considerations.

i. Relative size and location of the new continents.

ii. Location and direction of highland regions.

iii. Comparison of Atlantic and Pacific coasts: harbors.

(b) Natural Physical Divisions.

i. Nature of the West Indian group.

ii. Importance of the continental coastal plains.

iii. Value of river and lake systems.

(c) Suitability for European Colonization.

i. Range of temperature and rainfall.

ii. Adaptation of soil to agriculture and grazing.

iii. Kinds, extent and location of minerals.

(2) Organic Resources of Hispanic America.

(a) Species of Native Plant Life.

i. Forests as aids and obstacles.

ii. Extent and variety of food plants. 


\section{ERA OF DISCOVERY AND CONQUEST}

(b) Kinds and Distribution of Animal Life.

i. Effects of game and fish on early development.

ii. Larger American animals: historical importance.

Brief Descriptions:

Bullard, Panama, pp. 67-80, 94-108.

Bryce, South America, pp. 37-40, 75-88, 167-171, 206-207, 248-256, 368-372, 488-489, 527-528; (geographical sketches.)

Filsinger, Exporting to Latin America, pp. 389-392; (climate).

Shepherd, Latin A merica, pp. 107-1 2 I.

Sweet, History of Latin America, pp. 2 1-27.

Geographical Materials and Atlases:

Bartholomew, An Atlas of Economic Geography.

Bowman, South America, a Geography Reader.

Hale, Practical Guide to South America.

Keane, Stanford's Compendium of Geography and Travel.

Reclus, The Earth and Its Inhabitants.

Shepherd, Historical Atlas.

[For detailed descriptions, see books listed in the Bibliography under Travels and Descriptive Narratives.]

c. Native Life in Hispanic America.

(I) Classification of Native American Races.

(a) The Civilized Groups of Peoples.

i. Probable origin of the Indians: their name.

ii. Aboriginal development in Mexico and Yucatan.

iii. Evidences of culture in Peru.

(b) Barbarian and Savage Groups.

i. The "Red Indians" of North America.

ii. Relative development of island tribes.

iii. Distribution of aborigines in South America.

(2) Characteristics of the Indian.

(a) American Native Life and Individual Traits.

i. Contrasts in occupation, housing, food.

ii. The Indian as warrior and servitor. 
(b) Nature of Indian Institutions.

i. Forms of native government.

ii. Social and religious customs.

(c) Influence of the Indian on Colonization.

i. The inevitable contest for supremacy.

ii. Extinction of Indian civilization.

iii. The Indian and the labor problem.

iv. Degrees of extermination and assimilation.

\section{BRIEF REFERENCES:}

Bryce, South America, pp. 75-165, 452-454, 528-532.

Bullard, Panama, pp. 81-93.

Cambridge Modern History, vol. i, pp. 37-39.

Grant, Passing of the Great Race, pp. 76-77.

Koebel, South America, pp. I-I3.

MacHugh, Modern Mexico, pp. I-30.

Shepherd, Latin America, pp. 29-3I.

Sweet, History of Latin America, pp. 27-31.

Winter, Guatemala and Her People of Today, pp. I-I5.

\section{DetaIled Accounts:}

Ballou, Aztcc Land.

Bingham, In the Wonderland of Peru.

Church, Aborigines of South America.

Hrdlicka, Early Man in South America.

Joyce, Central American and West Indian Archacology; Mexican Archaeology, etc.

Markham, The Incas of Peru.

Spence, The Civilization of Ancient Mexico.

\section{Beginning of the Occupation of America}

a. First Stages in Colonization.

(I) Colonization of the West Indies.

(a) Motives for and Methods of Colonization.

i. West Indian types of colonies.

ii. The objects in colonial settlements.

iii. Early exploitation of the natives. 


\section{ERA OF DISCOVERY AND CONQUEST}

(b) Colonies Planted in the Era of Discovery.

i. Efforts and failures of Columbus.

ii. Occupation of the smaller islands.

iii. Colonization of Porto Rico.

iv. Conquest and settlements in Cuba.

(2) Settlements on the Mainland.

(a) Survey of the Central American Coast.

i. Projects of Ojeda, Nicuesa, Balboa.

ii. Motives for colonization in Darien.

iii. Difficulties and early failures in colonization.

(b) Summary of the Early Period.

i. Occupation of islands and isthmus.

ii. Destruction of natives.

iii. Disappointment in gold and spices.

BRIEF REFERENCES:

Abbott, Expansion of Europe, vol. i, pp. 163-165, 221-223.

Bolton and Marshall, Colonization, pp. 16-19, 29-32.

Bryce, South America, pp. 454-460.

Keller, Colonization, pp. $176-\mathrm{r} 77$.

Shepherd, Latin America, pp. Io-I r.

Sweet, Iistory of Latin America, pp. 46-54.

\section{LONGER ACCOUNTS:}

Bourne, Spain in America, pp. I32-20r.

Bullard, Panama, pp. $150-228$.

Jones, History of Latin America, pp. 20-3r.

Koebel, South America, pp. 26-35.

Muir, Expansion of Europe, pp. I-I 2.

Additional Readings:

Bates, The Path of the Conquistadores.

Gilman, Tales of the Pathfinders.

Helmolt, History of the World, vol. i.

Lummis, The Spanish Pioneers.

Morris, History of Colonization. 
h. The Conquest of Indian States.

(I) The Conquest of Mexico.

(a) Preparations for the Expedition.

i. Beginnings of Spanish interest in Mexico.

ii. The Commission of Cortes: his preparations.

(b) The Aztec War.

i. Factors favoring the Spaniards.

ii. Entering of Mexico City: the booty.

iii. Interruption and completion of the conquest.

(c) The Foundation of a Spanish State.

i. Rebuilding of Mexico City.

ii. New Settlements: their organization.

(2) Exploitation and Colonization of Peru.

(a) Early Projects for Conquest.

i. The attempts of Balboa.

ii. Early trials and failures of Pizarro.

iii. Effect of the Conquest of Mexico.

(b) The Taking of Peru.

i. Capture of Caxamarca and Cuzco.

ii. Measures for a colonial government.

iii. Civil war: opening of a new régime.

(c) Results of the Conquest.

i. Effects on Spanish migration.

ii. Opening up of Chile, Bolivia, Ecuador.

iii. Reaction of sudden wealth on Spain.

BRIEF REFERENCES:

Abbott, Expansion of Europe, vol. i, pp. 151-153, 165-169, 225-232.

Cambridge Modern History, vol. i, pp. 41-48.

Garcia-Calderon, Latin America, pp. 44-49.

Keller, Colonization, pp. I77-I8I.

Koebel, South America, pp. 47-55.

Porter, The Ten Republics, pp. 4-II.

Shepherd, Latin America, pp. II-т3. 


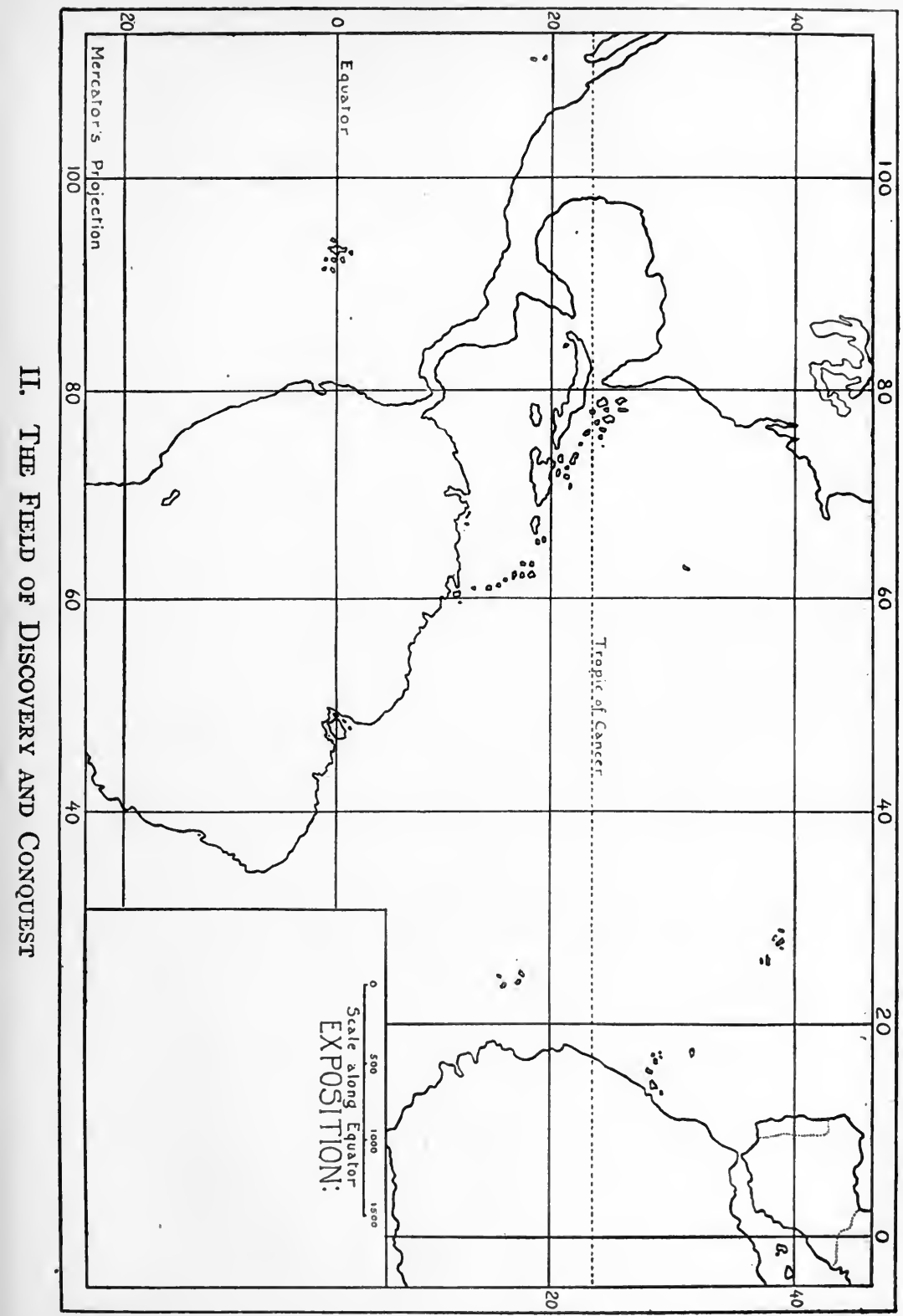





\section{IBERIAN COLONIES AND INSTITUTIONS}

LONGER ACCOUnTs:

Bolton and Marshall, Colonization, pp. 23-40, 42-46.

Bullard, Panama, pp. 229-252.

Jones, History of Latin America, pp. 31-63.

Sweet, History of Latin America, pp. 55-74.

Additional Readings:

Helps, The Spanish Conquest in America.

MacNutt, Fernando Cortes and the Conquest of Mexico.

Markham, Conquest of New Granada.

History of Peru.

Prescott, The Conquest of Mexico.

The Conquest of Peru.

Richman, The Spanish Conquerors.

\section{IBERIAN COLONIES AND INSTITUTIONS IN AMERICA}

i. Colonial Government and Territorial Extension

a. Methods of Iberian Imperial Control.

(I) Origin of Colonial Institutions.

(a) Spanish Governmental Machinery.

i. Nature of the Spanish kingship.

ii. Political bodies: their centralization and power.

(b) Colonial Administrative Development.

i. Relation of the Crown and the Indies.

ii. Evolution of new administrative councils.

iii. Re-application of Spanish judicial offices.

(2) Development of Hispanic Institutions in the Colonies.

(a) Nature of the Spanish Colonial Offices.

i. Evolution of the office of adelantado.

ii. Functions of the Captain-General.

iii. Creation of the Viceroy: his prerogatives.

(b) Inter-relation of Administrative Districts.

i. Government of the province: corregidor.

ii. Judicial districts: audiencia; presidencia.

iii. Types of municipal and local self-government. 
(c) Features of Portuguese Colonial Administration. i. Relation of Portuguese trade and colonization.

ii. The semi-feudal colonial land system.

iii. Changes in the administrative system.

iv. Governmental decentralization and inefficiency.

\section{BRIEF REFERENCES:}

Abbott, The Expansion of Europe, vol. i, pp. 232-235.

Bolton and Marshall, Colonization of North America, pp. 19-2I, 75.

Cambridge Modern History, vol. x, pp. 244-250.

Garcia-Calderon, Latin America, pp. 49-52.

Jones, History of South America, pp. 64-73.

Keller, Colonization, pp. 202-206, 302-315.

Koebel, South America, pp. 74-82.

Muir, Expansion of Europe, pp. I3-23.

Shepherd, Latin America, pp. 19-29.

Sweet, History of Latin America, pp. 19-29.

\section{Longer Accounts:}

Bourne, Spain in Amcrica, pp. 202-252.

Haring, The Spanish Colonial System.

Moses, Establishment of Spanish Rule in Amcrica.

- South America on the Eve of Emancipation, pp. I-99

- Spanish Dependencies in South America.

Roscher, The Spanish Colonial System.

b. The Rise of Spanish Agricultural Colonies.

(I) Spanish Penetration from the Caribbean.

(a) Foundations of Venezuela.

i. First discovery and explorations.

ii. Early settlements and misgovernment.

iii. Later development and exploitation.

iv. Handicaps from pirates and privateers.

(b) Establishment of New Granada.

i. Motives for colonization.

ii. Conquest of the native peoples: Bogotá.

iii. Economic basis for colonial growth. 


\section{IBERIAN COLONIES AND INSTITUTIONS}

(c) Organization of Central America and Mexico.

i. Coastal settlements and their government.

ii. Establishment and extension of Mexican government.

(2) Atlantic Settlements: Rio de la Plata.

(a) Early Attempts at Colonization.

i. Motives for and sites of early settlements.

ii. The long succession of colonial failures.

(b) Success of the'La Plata Settlements.

i. Growth of permanent communities.

ii. Evolution of colonial government.

iii. Pastoral development and economic progress.

BRIEF REFERENCES:

Abbott, Expansion of Europ:, vol. i, pp, 318-320.

Keller, Colonization, pp. 3r6-322.

Shepherd, Latin America, pp. 13-17.

Sweet, History of Latin America, pp. 7 I-83, I 29-138.

LONGER ACCOUNTS:

Bolton and Marshall, Colonization, pp. 233-256.

Koebel, South America, pp. 56-73.

Moses, South America on the Eve of Emancipation, pp. 32-57.

Additional Readings:

Cambridge Modern History, vol. i.

Chapman, Founding of Spanish California.

- The Northwest Expansion of New Spain.

Helmolt, History of the World, vol. i.

Lowery, The Spanish Settlements in the United States.

Moses, Spanish Dependencies.

Rodway, The West Indies and the Spanish Main.

b. The Portuguese in Brazil.

(I) Establishment of Portuguese Settlements.

(a) Motives and Methods of Early Colonization.

i. Discoveries and early exploration.

ii. Beginnings of colonization: convicts.

iii. The agricultural basis: sugar. 
(b) The Transition to Centralized Government.

i. The rapid increase in population.

ii. Practice of negro and Indian slavery.

iii. Revocation of feudal land grants.

iv. Establishment of a single government.

(2) Progress during the Colonial Era.

(a) Difficulties with European States.

i. Conflicts with French expeditions.

ii. Effects of the Portuguese-Spanish union, I580-I640.

iii. Attacks of Dutch and English.

iv. Final expulsion of rival colonists.

(b) Later Colonial Development.

i. Discovery of gold (1693) and effects.

ii. Misgovernment and internal dissension.

iii. Later political reform and economic prosperity.

\section{BRIEF REFERENCES:}

Abbott, Expansion of Europe, vol. i, pp. 153-154, I62-163, 235-236, 460-464.

Bryce, South America, pp. 366-370.

Cambridge Modern History, vol. i, pp. 48-50; vol. v, pp. 673-678.

Jones, History of South America, pp. 89-90.

Shepherd, Latin America, pp. 17-18.

Sweet, History of Latin America, pp. 84-93.

\section{LONGER ACCOUNTS:}

Keller, Colonization, pp. I31-167.

Koebel, South America, pp. 36-46, 95-ro9.

Stephens, Story of Portugal, pp. 220-235.

\section{Additional Readings:}

Helmolt, History of the World, vol. i.

Fiske, Discovery of America, vol. i.

Morris, History of Colonization.

Robertson, Rise of the Spanish-American Republics. 
2. General Survey of Colonial Economic DEVELOPMENT

a. Trade and Colonial Competition.

(I) Early International Conflict in America.

(a) Causes of Rivalry: the Mercantile System.

i. Trade competition in the colonial era.

ii. Application of the Spanish exclusion policy.

iii. Effects of the Treaty of Tordesillas.

iv. The temptation to violence: gold.

(b) Beginnings of Colonial Interference.

i. Formation of privileged trading monopolies.

ii. Rival European colonies: the Huguenots.

iii. Frequent resort to privateering: the English.

(2) Trade Conditions in the Americas.

(a) The Age of Buccaneering.

i. Origin and methods of pirates and privateers.

ii. Their objects and spheres of operation.

(b) Regulation of the Spanish Colonial Trade.

i. The convoy and fleet system.

ii. Distribution of goods; trade routes and fairs.

iii. Weaknesses of the system: the Asiento.

(c) Results on Colonial Development.

i. Handicaps of Hispanic coastal settlements.

ii. Unhealthy colonial economic conditions.

BRIEF REFERENCES:

Abbott, Expansion of Europe, vol. i, pp. 453-460.

Bolton and Marshall, Colonization, pp. 65-71.

Bourne, Spain in Amcrica, pp. 293-297.

Bryce, South America, pp. 15-19, 286 .

Hayes, Political and Social History of Modern Europe, vol. i, pp. 55-69.

Keller, Colonization, pp. 18ז-189.

Koebel, South America, pp. 83-94.

Shepherd, Latin America, pp. 18-19.

Sweet, History of Latin America, рр. то3-то4. 
SPecial 'Topics:

Bryce, South America, pp. 15-19.

Bullard, Panama, pp. 28I-336.

Cambridge Moäern History, vol. iii, pp. 49I-494; vol. v, pp. 68I-689; vol. $\mathrm{x}$, pp. 254-257, 272-275.

Haring, The Buccaneers in the West Indies in the XVII Century.

Moses, South America on the Eve of Emancipation, pp. 300-327.

Muir, Expansion of Europe, pp. 24-53.

\section{Additional Readings:}

Bancroft, Central America, vol. ii.

Chapman, Founding of Spanish California.

Esquemeling, The Buccaneers.

Froude, Englis' Seamen of the Sixtecnth Century.

Helmolt, History of the World, vol. i.

Lowery, The Spanish Settlements in the United States.

Moses, Spanish Dependencies in South America.

Roscher, The Spanish Colonial System.

Watson, Spanish and Portuguese South America, vol. i.

b. Internal Administration of the Colonies.

(I) Colonial Organization and Consolidation.

(a) Further Evolution of Government.

i. Steps in the redistribution of responsibility.

ii. Growth of population: creation of new provinces.

(b) Methods of Travel and Communication.

i. Number and character of provincial roads.

ii. Extensive use of waterways.

iii. Relation of transportation to political administration.

(2) Sources of Governmental Revenue.

(a) The Tariff System.

i. Nature and extent of import duties.

ii. Export tariff regulations.

(b) Types of Crown Monopolies.

i. Restriction of colonial manufacturing.

ii. Royal control of colonial commodities.

iii. Special prerogatives: e.g., lotteries, sale of offices. 
(c) The Multitude of Internal Taxes.

i. Pernicious effect of the alcabala.

ii. Extent of excise taxes.

iii. Value of the royal fifth: mining regulations.

iv. Varieties of Church demands.

(d) Effects of the Revenue System.

i. Bearing on economic welfare.

ii. Reaction of wealth on the mother countries.

\section{BRIEF REFERENCES:}

Abbott, Expansion of Europe, vol. i, pp. I70-173.

Akers, History of South America, pp. 6-1 2.

Bolton and Marshall, Colonisation, pp. 20, 47-50, 54-55, 75 f.

Cambridge Modern History, vol. v, pp. 680-684.

Keller, Colonization, 189-197, 207-215.

Shepherd, Latin A merica, pp. 42-43, 48-49.

Sweet, History of Latin America, pp., I06-І 10, I1 2-I I6.

LONger AcCounts:

Bourne, Spain in America, pp. 227-2

Koebel, South America, pp. I 10-I 22.

Moses, South America on the Eve of Emancipation, pp. 105-I 15.

\section{Additional Readings:}

Helmolt, History of the World.

Hume, The Spanish People.

Moses, The Spanish Dependencies in South America.

Roscher, The Spanish Colonial System.

Watson, Spanish and Portuguese South A merica.

c. Labor Problems and Industrial Progress.

(I) Growth of a Labor System.

(a) Spanish Attitude toward Labor.

i. Distaste for manual labor: reasons.

ii. Labor demands in the colonies.

iii. Exploitation of the available labor supply.

iv. Supplementary importations of negro slaves. 
(b) Methods Used in Indian Employment.

i. Forced labor: repartimiento, encomienda, mita.

ii. Adaptation to farming and mining.

(c) Labor Legislation and Control.

i. Labor abuses: effects on natives.

ii. Attitude of the Crown: early regulation.

iii. Reform agitation: Las Casas and the "New Laws." iv. Reaction of the labor system on respective races.

(2) Extent of Colonial Economic Development.

(a) Growth of the Mining Industry.

i. Kinds and location of mineral wealth.

ii. Methods of mining and shipping.

iii. Value of the annual mine production.

(b) Relative Importance of Agriculture and Grazing.

i. Slow transition of interest to planting and herding.

ii. Introduction of European plants and animals.

iii. Plantations as a permanent economic basis.

BRIEF REFERENCES:

Abbott, Expansion of Europe, vol. i, pp. 315-326.

Akers, History of South America, pp. I2-18.

Bolton and Marshall, Colonization, pp. 2I-23, 50.

Cambridge Modern History, vol. x, pp. 257-267.

Jones, South America, pp. 73-80.

Keller, Colonization, pp. 22 I-25I, 257-282.

Shepherd, Latin America, pp. 38-4.3, 47-49.

Sweet, History of Latin America, pp. 104-I08, I ro-Ir2.

LONGER ACCOUNTS:

Bourne, Spain in America, pp. 209-215, 269-28I.

Bullard, Panama, pp. 253-28I, 356-369.

Koebel, South America, pp. I22-I4I.

Moses, South America on the Eve of Emancipation, pp. 167-217.

Additional Readings:

Helmolt, History of the World.

Hume, The Spanish People. 
Moses, Spanish Dependencies in South America.

Roscher, The Spanish Colonial System.

Watson, Spanish and Portuguese South America.

\section{Eightennth Century Social Conditions}

a. Religious Institutions in the Colonies.

(I) The Church as a Colonizing Agency.

(a) Work of the Early Priests.

i. Their aid in exploration.

ii. The conversion and protection of the Indians.

iii. Priests as colonial chroniclers: Las Casas.

(b) Establishment of Religious Orders.

i. Efforts of the Jesuits.

ii. Founding and success of missions: Paraguay.

iii. Activities of other clerical orders.

(c) Relations of Church and State.

i. Church influence in politics: Uruguay.

ii. Later expulsion of the Jesuits.

(2) The Church in Social and Economic Life.

(a) The Church as a Social Factor.

i. Civilizing influences of the institution.

ii. Church control and spread of education.

iii. The Inquisition: control of morals.

(b) Property of the Church.

i. Rapid increase in Church personnel.

ii. Numbers of religious institutions.

iii. Sources and extent of Church revenue.

BRIEF REFERENCES:

Abbott, Expansion of Europe, vol. i, pp. 457-459.

Bolton and Marshall, Expansion, pp. 235-240.

Cambridge Modern History, vol. i, pp. 60-63; vol. x, pp. 270-27I.

Garcia-Calderon, Latin America, pp. 52-53.

Jones, History of Latin America, pp. 81-87.

Sweet, History of Latin America, pp. 82, 124-1 25. 


\section{LONGER ACCOUNTS:}

Bourne, Spain in America, pp. 302-319.

Bullard, Panama, pp. 253-280.

Keller, Colonization, pp. 197-200, 283-302.

Moses, South America on the Eve of Emancipaiion, pp. II $5^{-142 .}$

Shepherd, Latin America, pp. 49-59.

AdDitional ReAdings:

Cunninghame-Graham, $A$ Vanished Arcadia.

Lea, The Inquisition in the Spanish Dependencies.

Moses, Spanish Dependencies in South America.

Mozans, Along the Andes.

Watson, Spanish and Portuguese South America, vol. i.

b. Phases of Social Evolution.

(I) Organization of Colonial Society.

(a) The Contact of Races.

i. Absence of Spanish family life in Americi.

ii. Iberian tendencies: mingling with natives.

iii. Natural results of unequal race contact.

(b) Composition of the Latin Americans.

i. Relative proportions of the three racial elements.

ii. Complexity of mixtures: their nomenclature.

iii. Racial comparison of Latin-American states.

(c) The Social Scale.

i. Rise of the class system.

ii. Comparison with present conditions.

(2) Practical Aspects of the Class System.

(a) Social Organization and Politics.

i. Dominance of native-born Spanish.

ii. The position occupied by creoles.

iii. Status of the mixed classes: divide et impera.

iv. Conditions in Portuguese Brazil.

(b) Social Customs and Style of Life.

i. Relation of wealth and position

ii. Social and moral abuses. 


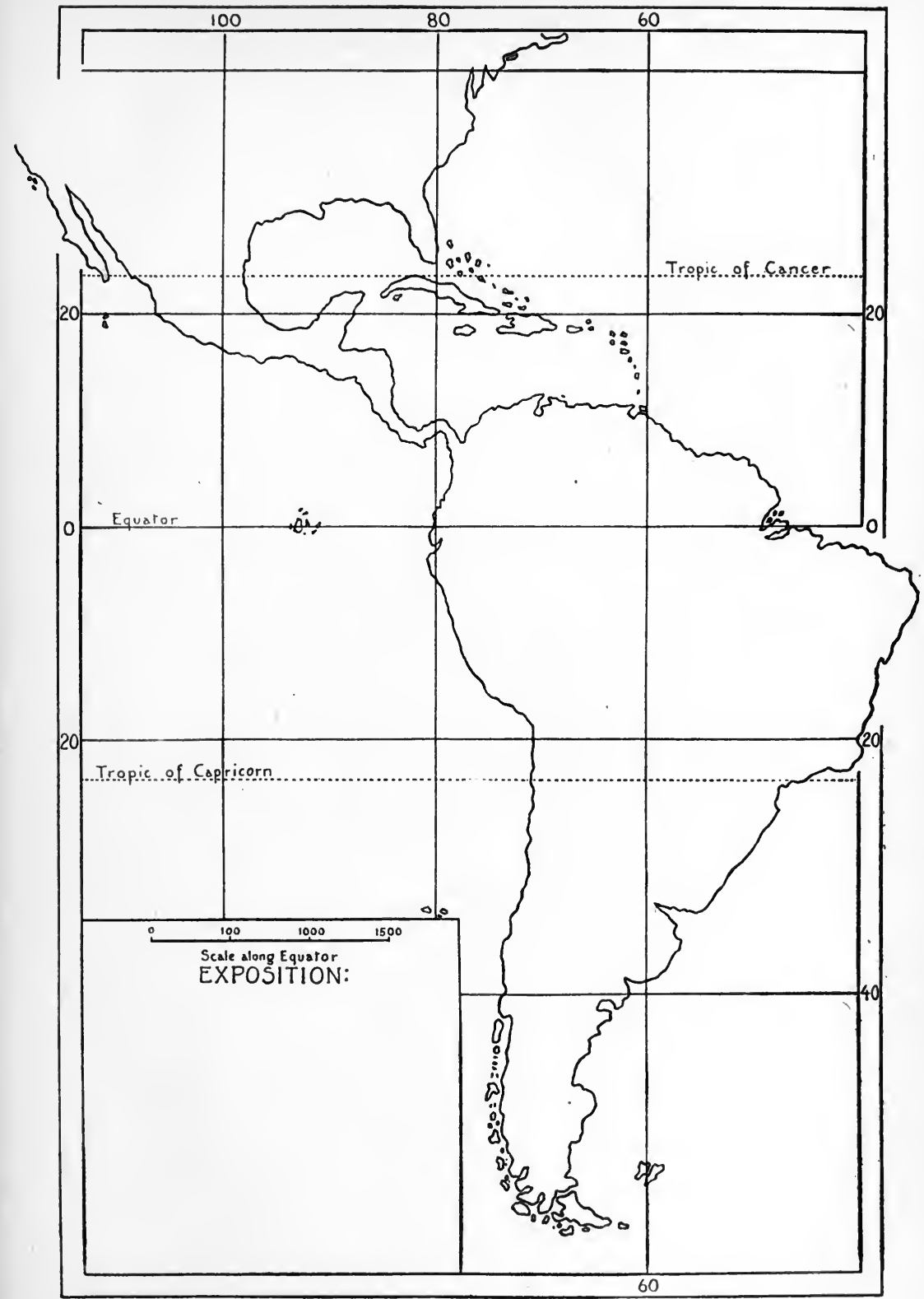

III. Colonial Expansion in America 
iii. Colonial contrasts in country and city.

iv. Degrees of culture, education, and literature.

\section{BRIEF REFERENCES:}

Bolton and Marshall, Colonization, p. 76.

Cambridge Modern History, vol. i, pp. 63-66; vol. x, p. 268.

Keller, Colonization, pp. 21 5-220.

Sweet, History of Latin America, pp. I22-I24, I25-I 28.

\section{LONGER ACCOUNTS:}

Bourne, Spain in America, pp. 253-268.

Bryce, South America, pp. 454-463.

Garcia-Calderon, Latin A merica, pp. 44-57.

Moses, South America on the Eve of Emancipation, pp. 100-I 18.

Shepherd, Latin America, pp. 31-38, 59-68.

\section{Additional ReAdings:}

Hale, The South Americans.

Moses, Establishment of Spanish Rule in America, vol. ii.

- Spanish Dependencies in South America.

Watson, Spanish and Portuguese South America. 


\section{EVOLUTION OF THE LATIN-AMERICAN NATIONS}

\section{A. THE STRUGGLES FOR INDEPENDENCE \\ I. The Liberation of Spanish South America}

a. Preliminaries of Latin-American Independence.

(I) Causes of General Discontent.

(a) Factors in the Spanish Colonial Policy.

i. Despotic character of the Spanish colonial régime.

ii. Administrative abuses of colonial officials.

iii. Effects of Spanish economic policy.

iv. Official jealousy: creoles vs. native Spanish.

(b) The Intellectual Basis: Invasions of Ideas.

i. Constant evasion of Spanish censorship.

ii. Introduction of French and English philosophy.

iii. Influence of the American and French revolutions.

iv. Effects of Latin-American travel abroad.

(2) The Immediate Background of the Revolutions.

(a) The European Situation.

i. French occupation of Portugal and Spain.

ii. Napoleon's designs on American colonies.

iii. Colonial loyalty: the juntas.

iv. Paradoxical situation of the colonies.

(b) Latin-American Characteristics in 1806.

i. Propaganda of English and American agents: motives.

ii. Organization of revolutionary societies abroad.

iii. Absence of concrete issues for revolution.

iv. General lack of revolutionary interest in Latin America. 


\section{THE STRUGGLES FOR INDEPENDENCE}

BRIEF REFERENCES:

Akers, History of South America, pp. 19-20.

Bryce, South America, pp. 491-500.

Cambridge Modern History, vol. ix, pp. 268-269, 399, 406; vol. x, pp. 275-279.

Garcia-Calderon, Latin America, pp. 58-60, 8I-85.

Hart, Monroe Doctrine, pp. 20-26.

Paxson, The Independence of the South American Republics, pp. 45-47.

Shepherd, Latin A merica, pp. 69-74.

Sweet, History of Latin America, pp. 140-143.

LONGER ACCOUNTS:

Bullard, Panama, pp. 356-372; (general considerations).

Latané, The United States and Latin America, pp. 3-20.

Moses, South America on the Eve of Emancipation, pp. 100-I 18.

Watson, Spanish and Portuguese South America, vol. ii, pp. 27 I-3ig.

Additional Readings:

Chandler, Inter-American Acquaintances.

Mitre, The Emancipation of South America.

Niles, A History of South A merica.

Zahm, Through South America's Southland.

b. Early Phases of the Revolutionary Movements.

(I) Composition of the Revolutionary Forces.

(a) South American Patriots.

i. Importance of the personal element in revolution.

ii. Preparation and aims of Miranda, San Martin, Bolivar, etc.

iii. Their contributions to Latin-American history.

(b) Further Active Elements in the Wars of Liberation.

i. Disaffection of the creoles: their revolt.

ii. Enlistment of English and American volunteers.

(2) The First Series of Revolts.

(a) The Services of Francisco Miranda.

i. His early efforts abroad: results.

ii. The revolt of 1797 : its failure.

iii. The filibustering expedition of 1806 . 
(b) Beginnings of Organized Revolt.

i. Events in Spain: formation of the Caracas junta.

ii. The Venezuelan declaration of independence.

iii. Reverses: imprisonment and death of Miranda.

(c) The Revolution in Argentina.

i. English operations in South America, r806-1807.

ii. Formation of a central Argentine junta, r807.

iii. Rise of the creole party: failures of the junta.

BRIEF REFERENCES:

Akers, History of South America, pp. 23-34.

Bullard, Panama, pp. 372-385.

Cambridge Modern History, vol. x, pp. I39-14I, 280-289.

Hart, The Monroe Doctrine, pp. 26-29.

Jones, History of South America, pp. 92-98.

Koebel, South America, pp. I54-1 58 .

Latané, The United States and Latin America, pp. 20-29.

Paxson, Independence of the South American Republics, pp. 47-56.

Shepherd, Latin America, pp. 74-75.

Sweet, History of Latin America, pp. I43-I49.

LONGER ACCOUnts:

Garcia-Calderon, Latin America, pp. 60-8r.

Koebel, British Exploits in South America, pp. IOI-1 58.

Moses, South America on the Eve of Emancipation, pp. 254-299.

Additional Readings:

Mitré, The Emancipation of South America.

Niles, A History of South America.

Robertson, Francisco Miranda and the Revolutionizing of South America.

Walton, Revolutions of Spain.

c. The Final Series of South American Revolutions.

(I) Liberation of the Southern Spanish Colonies.

(a) The Policy of the Restored Spanish Bourbons.

i. Lack of concession or conciliation.

ii. Yielding of most of the provisional governments.

iii. The Argentine declaration of independence (r8I6). 
(b) Extension of the Argentine Movement.

i. Efforts of San Martin: revolution in Uruguay.

ii. Activities of the Argentine fleet.

iii. The liberation of Chile ( $1817-1818)$.

(2) Campaigns in Northern South America.

(a) The operations of Simon Bolivar.

i. Establishment of a second Venezuelan Republic.

ii. Freeing of New Granada: foreign aid.

iii. The final liberation of Venezuela (I821).

(b) Extension of the Program: Invasion of Peru.

i. English coöperation: Lord Cochrane.

ii. San Martin's successful campaign in Peru.

iii. Formation of a provisional government.

(c) The Final Act in the Revolutionary Drama.

i. Liberation of Ecuador: Sucré (I82I-I822).

ii. Concentration of forces in Peru.

iii. Withdrawal of San Martin before Bolivar.

BRIEF REFERENCES:

Akers, History of South America, pp. 20-23.

Bullard, Panama, pp. 385-396.

Cambridge Modern History, vol. x, pp. 290-302.

Hart, Monroe Doctrine, pp. 30- 32 .

Koebel, South America, pp. 176-184.

Shepherd, Latin America, pp. 75-77.

Sweet, History of Latin America, pp. 149-163.

LONGER ACCOUNTS:

Chandler, Intcr-American Acquaintances.

Jones, History of South America, pp. 98-1 16.

Koebel, British Exploits in South America, pp. 163-23г.

Latané, The United States and Latin America, pp. 29-47.

Paxson, Independence of the South American Republics, pp. 57-101.

Additional Readings:

Dawson, History of South America, 2 vols.

Mitré, The Emmancipation? of South A merica. 
Niles, History of South America.

Robertson, Rise of the Spanish American Republics.

Watson, Spanish and Portuguese South America.

\section{Minor Revolutionary Movements}

a. The Independence of Brazil.

(I) Relations of Portugal and Brazil.

(a) French Occupation of Portugal.

i. Exile of the Portuguese royal family.

ii. Reorganization of the Brazilian government.

iii. Inauguration of a new commercial policy.

iv. Financial condition of the colony.

(b) Basis of the Revolution in Brazil.

i. The monopoly of offices by Portuguese.

ii. Levying of new and heavy taxes.

(2) The Nationalist Movement in Brazil.

(a) The Revolution of 1820 .

i. Suppression of incipient revolts.

ii. Establishment of representative government.

(b) The Separation of Brazil from Portugal.

i. Return of the royal court to Portugal.

ii. Declaration of Brazilian independence, I822.

iii. Formation of the Empire of Brazil.

iv. The value of British aid.

BRIEF ACCOUNTS:

Hart, Monroe Doctrine, pp. 26, $3 \mathrm{r}$.

Jones, History of South America, pp. 107-109.

Shepherd, Latin America, pp. 77-79.

Sweet, History of Latin America, pp. 165-168.

LONGER ACCOUNTS:

Cambridge Modern History, vol. x, pp. 310-319.

Dawson, History of South America, vol. i, pp. 287-300.

Koebel, British Exploits in South A merica, pp. 214-234.

South America, pp. 185-200. 
FURTHER READING:

Helmolt, History of the World.

Mitré, The Emancipation of South America.

Moses, Spanish Dependencies in South America.

Niles, A History of Soulh America.

Robertson, Rise of the Spanish American Republics.

Winsor, Narrative and Critical History of America, vol. viii.

[For further references, see individual histories of Brazil.]

b. Revolution in Mexico and the Caribbean.

(I) The Struggle in Mexico.

(a) The first Phase of the Revolution.

i. Conditions producing revolution: $c f$. South America.

ii. Origin of the revolt: lack of enthusiasm.

iii. Character and plans of Miguel Hidalgo.

iv. Failure of the insurgents: Hidalgo's death.

v. The attempts of José Morelos.

(b) The Imperial Phase.

i. Iturbidé and the "Plan of Iguala."

ii. Attitude of Spain toward Mexican independence.

iii. Rapid rise and fall of the Empire.

(c) Final Phase of the Struggle.

i. Effects of the Spanish revolution.

ii. Establishment of the Mexican Republic.

(2) Revolutions in Central America and the West Indies.

(a) The Independence of Central America.

i. Previous relations of the Crown and the colonies.

ii. Character of the struggle for independence.

iii. Formation of a federal republic.

(b) Conditions in the West Indies.

i. Quiet prosperity in Cuba and Porto Rico.

ii. Revolts in Haiti: Toussaint L'Ouverture.

iii. Subsequent separation of Santo Domingo. 


\section{BRIEF REFERENCES:}

Cambridge Modern History, vol. x, pp. 302-307.

Latané, The United States and Latin America, pp. 45-47.

Shepherd, Latin America, pp. 79-8r.

Sweet, History of Latin America, pp. I68-г 73 .

\section{LONGER ACCOUNTS:}

Goodrich, The Coming Mexico, pp. 55-66.

MacHugh, Modern Mexico, pp. I8-63.

Winter, Mexico and Her People of Today, pp. 165-181.

Additional Readings:

Bancroft, The History of Mexico.

Mitré, The Emancipation of South America,

Munro, The Five Republics of Central America.

Robertson, Rise of the Spanish American Republics.

Rodway, The West Indies and the Spanish Main.

[For further references, see individual histories of Mexico and the states of Central America.]

3. The Establishment of Latin-American

\section{INDEPENDENCE}

a. Evolution of a Policy of American Isolation.

(I) Early Relations between the United States and Latin America.

(a) Commercial Intercourse.

i. Extent and nature of the Latin-American trade.

ii. Beginnings of acquaintanceship.

(b) United States' Aid to Independence.

i. Influence of the American Revolution.

ii. American volunteers and filibustering expeditions.

iii. Diplomatic relations with the new republics.

iv. Recognition of newly-constituted states.

(2) Formation of an Idea of American Isolation.

(a) The Doctrine of European Aloofness.

i. Real basis for the Doctrine of the Two Spheres.

ii. Elements in the American Revolution.

iii. Washington's ideas of isolation. 


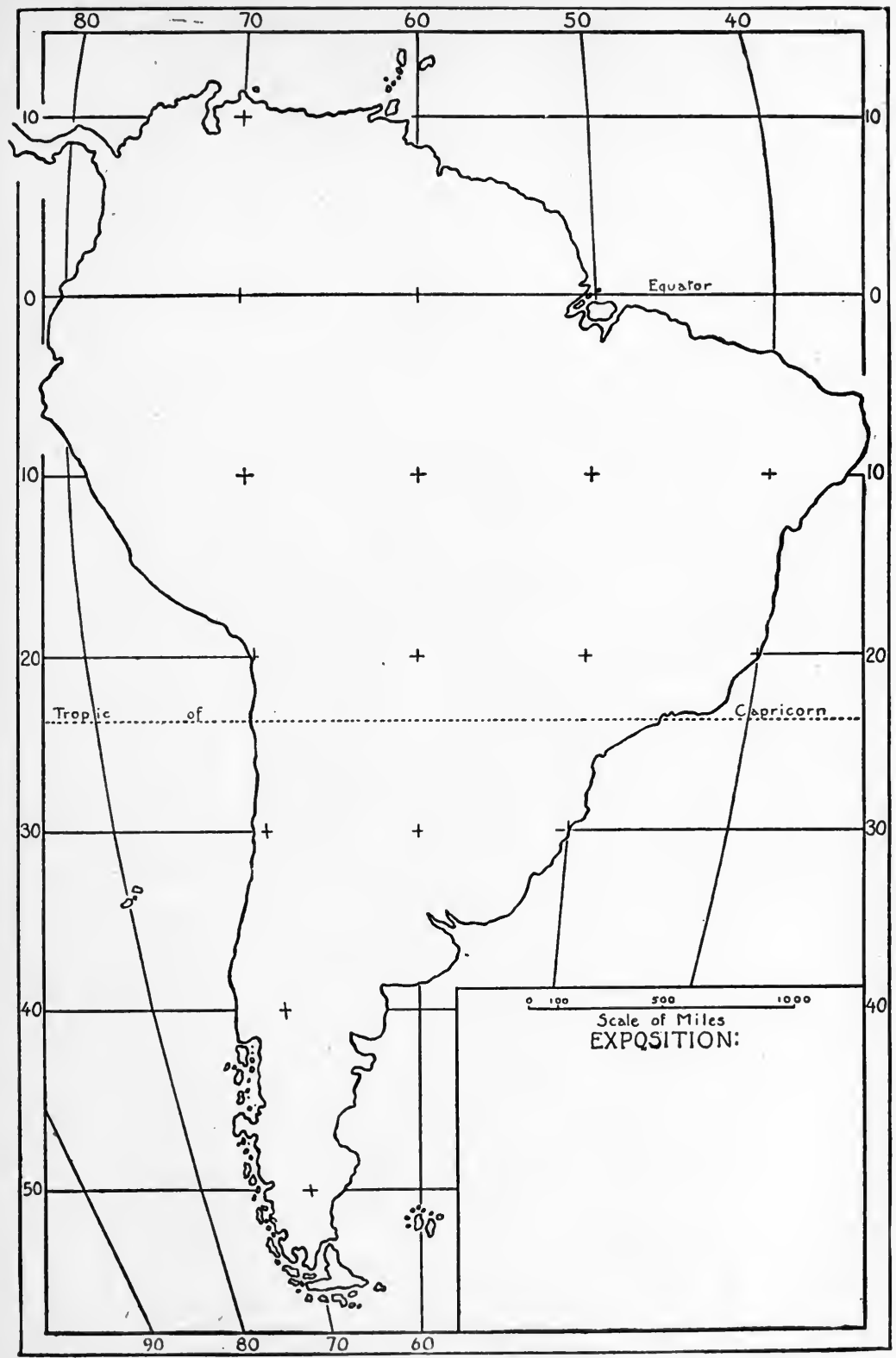

IV. The Revolutionary Period in South America 
. 
(b) Early Formulations of the Monroe Doctrine.

i. Attitude of Jefferson and Adams toward Latin America.

ii. Beginnings of the recognition policy: Clay.

iii. John Quincy Adams' policy of neutrality.

iv. Changes produced by the European Concert.

\section{BRIEF REFERENCES:}

Henderson, American Diplomatic Questions, pp. 289-293.

Latané, The United States and Latin America, pp. 48-54.

Shepherd, Latin America, pp. 76-77.

Sweet, History of Latin America, pp. 173-174.

Tucker, The Monroe Doctrine: Its Origin and Growth, pp. I-I I.

\section{LONGer ACCOUNTS:}

Chandler, Inter-A merican Acquaintances, pp. I-II4.

Hart, The Monroe Doctrine, pp. I-54.

Paxson, Independence of the South American Republics, pp. 17-44, 102-177.

\section{FURTHER READING:}

Edgington, The Monroe Doctrine.

Foster, A Century of American Diplomacy.

Hull, The Monroe Doctrine, National or International?

Manning, Early Diplomatic Relations between the United Stales and Mexico.

Reddaway, The Monroe Doctrine.

b. Recognition: The Monroe Doctrine.

(I) The European Situation, I815-1823.

(a) Formation of the "Holy Alliance."

i. Purpose and methods of the Alliance.

ii. Application of the Doctrine of Intervention.

iii. The Congresses and changes in the Alliance.

(b) Plans for Intervention in America.

i. Motives for the recovery of the Spanish colonies.

ii. The firm opposition of England. 
(c) The Basis of the Monroe Pronouncement.

i. The British proposal to the United States.

ii. Authorship of the "Monroe" Doctrine.

iii. Reasons for separate Anglo-American protests.

(2) The Message of President Monroe, I823.

(a) Character of the Message.

i. Scope of the statement.

ii. Analysis of the document: its two phases.

iii. Its relation to Latin-American independence.

(b) Reception of the Message.

i. Attitude of the continental Powers.

ii. Latin-American understanding of the document.

iii. The foundation of an "American" policy.

iv. Beginning of Pan-American hopes.

\section{BRIEF REFERENCES:}

Cambridge Modern History, vol. x, pp. 307-309.

Foster, A Century of American Diplomacy, pp. 440-45I.

Hart, The Monroe Doctrine, pp. 55-68.

Koebel, History of South America, pp. 228-236.

Tucker, The Monroe Doctrine, pp. 12-22.

\section{LONGER ACCOUNTS:}

Chandler, Inter-American Acquaintances, pp. I49-I70.

Edgington, The Monroe Doctrine, pp. I-54.

Henderson, American Diplomatic Questions, pp. 294-34r.

Latane, The United States and Latin America, pp. 54-82.

Paxson, Independence of the South American Republics, pp. I78-25I.

\section{Additional Readings:}

Chadwick, The Relations of Spain and the United States.

Crichfield, American Supremacy, vol. i.

Gilman, James Monroe.

Manning, Early Diplomatic Relations.

Moore, Digest of International Law.

Reddaway, The Monroe Doctrine. 


\section{B. RISE OF THE SOUTH AMERICAN REPUBLICS}

I. Rise of Progressive Latin-American States

a. Development of Argentina.

(I) Beginnings of the Argentine Republic.

(a) Physical Characteristics of the State.

i. Size and extent of Argentina.

ii. Three physical divisions of the country.

iii. Composition of the Argentine population.

(b) The Early Period of Argentine Independence.

i. The provisional governments, I810-1824.

ii. Formation of a federal state.

iii. Territorial disputes with neighboring states.

(2) Later National Problems and Development.

(a) The Period of Dictators.

i. Rosas: policies and personality.

ii. The war against the Unitarians.

iii. The fall of Rosas: the new constitution.

iv. Administration of Urquiza.

(b) Transition to Political Tranquillity.

i. Struggles between Buenos Aires and the provinces.

ii. Intervention of France and England.

iii. Stabilization of the government, I880.

iv. Settlement of recent boundary disputes.

(c) Social and Industrial Progress.

i. Educational and cultural advancement.

ii. Rise of industries: grazing and farming.

iii. Growth of population: cf. Buenos Aires.

BRIEF REFERENCES:

Aughinbaugh, Selling Latin America, pp. 3I-49; (industries).

Cambridge Modern History, vol. xii, pp. 679-680. 
Garcia-Calderon, Latin America, pp. I34-I48.

Koebel, South America, pp. 272-282.

Sweet, History of Latin America, pp. I89-I92.

Verrill, Getting Together with Latin America, pp. I25-130.

\section{LONGER ACCOUNTS:}

Akers, History of South America, pp. 35-г 30.

Bryce, South America, pp. 315-348; (descriptive).

Dawson, History of South America, vol. i, pp. 37-I6r.

Dodd, Modern Constitutions, vol. i, pp. I-30; (documentary).

Jones, History of South America, pp. I94-2I7, 3I 5-326.

Porter, The Ten Republics, pp. I I I-I37.

Ross, South of Panama, pp. II4-I38; (cultural).

\section{FURTHER READING:}

Hammerton, The Real Argentina.

Hirst, Argentina.

Koebel, Argentina, Past and Present.

Martinez and Lewandowski, The Argentine in the 2oth Century.

Mills, Argentina.

Winter, Brazil and Her People of Today.

b. The Progress of Brazil.

(I) Establishment of Brazilian Independence.

(a) Physical and Social Considerations.

i. Extent of Brazil: boundaries and resources.

ii. Varieties of climate and products.

iii. Elements comprising the population.

(b) Relations of Portugal and Brazil.

i. Establishment of the Empire of Brazil, I822.

ii. The Revolution: reign of Pedro I (I822-I834).

(2) Development of Empire and Republic.

(a) Reign of the Emperor Pedro II (I834-I889).

i. Abdication and departure of Pedro I.

ii. Degree of self-government under the regency.

iii. Wars with Argentina and Paraguay. 
(b) Establishment of the Republic.

i. Overthrow of the imperial government.

ii. Creation of a military dictatorship.

iii. The republican constitution: its nature.

iv. Subsequent peaceful political development.

(c) Social and Industrial Progress.

i. Slavery and the slave trade: emancipation (I888).

ii. Brazilian education and culture.

iii. Agricultural development of the interior.

iv. Growth of foreign trade: immigration.

BRIEF REFERENCES:

Aughinbaugh, Selling Latin America, pp. 13-30; (industrial).

Cambridge Modern History, vol. x, pp. 320-339; vol. xii, pp. 674-676.

Garcia-Calderon, Latin America, pp. 180-190.

Koebel, South A merica, pp. 20I-227.

Sweet, History of Latin America, pp. 196-200.

Verrill, Getting Together with Latin A merica, pp. I36-I45.

LONGER ACCOUNTS:

Akers, History of South America, pp. 231-321.

Bryce, South A merica, pp. 368-422; (descriptive).

Dawson, History of South America, vol. i, pp. 287-513.

Dodd, Modern Constitutions, vol. i, pp. r49-182; (documentary).

Jones, South America, pp. I 7 I-193.

Porter, The Ten Republics, pp. 156-r82.

AdDitional ReAdings:

Bruce, Brazil and the Brazilians.

Buley, North Brazil.

- South Brazil.

Denis, Brazil.

Elliott, Brazil Today and Tomorrow.

Winter, Brazil and Her People of Today.

c. The Growth of Chile.

(I) Rise of the Chilean Nation.

(a) Natural Foundations of Chile.

i. Geographical boundaries: climate and soil.

ii. Chile as an economic unit. 
(b) The Period of Political Transition.

i. The government of O'Higgins: his downfall.

ii. Chronic revolution and political chaos.

(2) Establishment of Stable Government.

(a) Formation of a United Nation.

i. Rise of the Conservatives: Portales.

ii. The War with Spain, I865.

iii. The transition to Liberal control.

iv. Success in the Peru-Bolivia War.

(b) Recent Chilean Politics.

i. Civil war: President versus Congress.

ii. The Baltimore incident, I892.

iii. Continuation of boundary disputes.

(c) Economic and Social Development.

i. Rapid growth of industries and commerce.

ii. Exploitation and value of the nitrate fields.

iii. Social problems: immigration.

\section{BRIEF REFERENCES:}

Aughinbaugh, Selling Latin America, pp. 67-78.

Cambridge Modern History, vol. xii, pp. 677-680.

Garcia-Calderon, Latin America, pp. I64-I 79.

Koebel, South America, pp. 264-27 I.

Sweet, History of Latin America, pp. 193-196.

Verrill, Getting Together with Latin America, pp. I50-I53.

\section{LONGER ACCOUNTS:}

Akers, History of South America, pp. 321-554.

Bryce, South America, pp. 206-256; (descriptive).

Dawson, History of South America, vol. ii, pp. I35-235.

Dodd, Modern Constitutions, vol. i, pp. 227-264; (documentary).

Jones, South America, pp. 293-3I4.

Porter, The Ten Republics, pp. 183-204.

Ross, South of Panama, pp. 94-1r3; (social and cultural). 
AdDitional ReAdings:

Elliott, Chile.

Koebel, Modern Chile.

Maitland, Chile.

Mansfield, Progressive Chile.

Mills, Chile.

d. The National History of Uruguay.

(I) Formation and Rise of Uruguay.

(a) The Bases of National Life.

i. Physiographic conditions: soil and climate.

ii. Physical relations to surrounding states.

iii. Racial elements: a "white man's country."

(b) Early Political Struggles and Vicissitudes.

i. The artificial origin of Uruguay.

ii. Early relations with Brazil and Argentina.

iii. Foundation of the Republic: Artigas.

(2) Later Political and Economic Development.

(a) Domestic and Foreign Struggles.

i. Formation of political parties: wars.

ii. Intervention of Argentina: results.

iii. Continuation of factional struggles.

iv. Establishment of stable government: the constitution.

v. Contemporary government and politics.

(b) Social and Economic Conditions.

i. Rapid growth of population: total.

ii. Rise of industries and commerce.

iii. Centering of national life in Montevideo.

iv. Intellectual and religious conditions.

BRIEF REFERENCES:

Aughinbaugh, Selling Latin America, pp. 49-56; (economic)

Cambridge Modern History, vol. xii, pp. 680-683.

Garcia-Calderon, Latin America, pp. I27-133.

Porter, The Ten Republics, pp. 262-275.

Sweet, History of Latin America, pp. 200-20i.

Verrill, Getting Together with Latin America, pp. 2 I I-216. 


\section{LONGER ACCOUNTS:}

Akers, History of South America, pp. 196-231.

Bryce, South Amcrica, pp. 349-365; (descriptive).

Dawson, History of South America, vol. i, pp. 227-287.

Jones, South America, pp. 218-230.

Koebel, South America, pp. 272-282.

\section{Additional Readings:}

Domville-Fife, A Chapter in the United States of Brazil.

Koebel, Uruguay.

Shepherd, The Hispanic Nations of the New World.

\section{Course of the Undeveloped Republics}

a. The Caribbean States: Venezuela and Colombia.

(I) The Career of Venezuela.

(a) Foundations of Modern Venezuela.

i. Relative proportions of racial elements.

ii. Physiography and natural resources.

iii. National beginnings: inclusion in Great Colombia.

(b) Political Struggles of the Nineteenth Century.

i. Revolt from Colombia: federalism.

ii. The series of dictators: Guzman Blanco; Castro.

iii. Bankruptcy and foreign complications.

(c) Social and Economic Conditions.

i. Social conditions: ignorance and stagnation.

ii. Reaction of civil war on trade and industry.

(2) Struggles of Independent Colombia.

(a) Beginnings of Colombian Statehood.

i. Physical and racial foundations.

ii. Separation from Spain: New Granada.

(b) Internal Problems and Progress.

i. Decentralization: the United States of Colombia.

ii. Prevalence of domestic warfare: dictators.

iii. Return to centralization: the Republic.

iv. Financial and economic distress. 
(c) Late International Developments.

i. The revolution and independence of Panama.

ii. Controversies with the United States of America.

BRIEF REFERENCES:

Cambridge Modern History, vol. xii, pp. 673-674.

Garcia-Calderon, Latin America, pp. roI-I I2, 201-212.

Koebel, South America, pp. 283-294.

Sweet, History of Latin America, pp. 176-18r.

Verrill, Getting Together with Latin America, pp. 216-221, 153-159.

\section{LONGer AcCounts:}

Akers, History of South America, pp. 591-647.

Aughinbaugh, Selling Latin America, pp. I14-1 38; (economic).

Dawson, History of South America, vol. i, pp. 347-475.

Jones, History of South America, pp. I1 7-154.

Porter, The Ten Republics, pp. 276-288, 205-218.

\section{Additional Readings:}

Dalton, Venezuela.

Eder, Colombia.

Levine, Colombia.

Petre, The Republic of Colombia.

Shepherd, The Hispanic Nations of the New World.

b. The Pacific States: Ecuador and Peru.

(I) Ecuador in the Past Century.

(a) Basis of Modern Ecuador.

i. Character of the country and people.

ii. Relation to the Spanish presidency of Quito.

iii. Conditions after independence: military struggles. iv. Separation of Ecuador, 1830: Flores.

(b) Annals of the New State.

i. The succession of wars and dictators.

ii. Internal improvements: Garcia Moreno.

iii. Relations of Church and State.

iv. Recent social and economic conditions. 
(2) The Course of Peru.

(a) Early Series of Political and Economic Handicaps.

i. Geographical and social foundations of Peru.

ii. The second struggle for independence.

iii. The series of personal and factional wars, I826-1844.

(b) Rise of a Centralized Peruvian State.

i. The constructive work of Ramon Castilla.

ii. The successful war with Spain, 1865-1866.

iii. Discovery and exploitation of nitrate deposits.

iv. Internal development and the national debt.

(c) The Chilean War and Reconstruction.

i. Nature and outcome of the war with Chile, I880I883.

ii. The financial settlement: foreign interests.

iii. Recent phases of the Tacna-Arica controversy.

iv. Present political and social stability.

BRIEF REFERENCES:

Cambridge Modern History, vol. xii, pp. 673-674.

Garcia-Calderon, Latin America, pp. 213-22I, II3-I2I.

Koebel, South America, pp. 283-294.

Sweet, History of Latin America, pp. 181-186.

Verrill, Getting Together with Latin America, pp. I74-180, 205-209.

LONGER ACCOUnTs:

Akers, History of South America, pp. 505-554, 577-59r.

Aughinbaugh, Selling Latin America, pp. 91-I I3; (economic).

Dawson, History of South America, vol. i, pp. 285-347, 3-135.

Jones, History of South America, pp. 155-170, 264-292.

Porter, The Ten Republics, pp. 219-230, 245-261.

Ross, South of Panama, pp. 3-93.

Additional Readings:

Enock, Ecuador. Peru.

Martin, Peru of the 2oth Century.

Shepherd, The Hispanic Nations of the Nerw World.

Vivian, Peru 


\section{RISE OF THE SOUTH AMERICAN REPUBLICS $\sigma_{3}$}

c. The Interior States: Bolivia and Paraguay.

(I) The Evolution of Bolivia.

(a) Origins of Bolivia.

i. The geography of the region.

ii. Its relation to the wars for independence.

iii. The succession of dictators and alliances.

(b) From Anarchy to Political Stability.

i. Bolivia a political outcast.

ii. Restoration of order by strong men.

iii. The war with Chile: loss of seacoast.

(c) Social and Economic Conditions.

i. Bolivia's mining record.

ii. Exploitation of the lowland district.

iii. Character of the population: the Church.

(2) The Rise and Struggles of Paraguay.

(a) Early Chapters in Paraguayan History.

i. Physical characteristics of the country.

ii. Early settlers: arrival of the Jesuits.

iii. Achievement of separation and independence.

(b) Political Development of the Nation.

i. Francia's reign: a policy of isolation.

ii. The régime of the elder Lopez.

iii. Francisco Lopez and the Paraguayan War.

iv. Defeat and practical ruin.

(c) Paraguay since 1870.

i. Political history: increase in population.

ii. Present agricultural possibilities.

BRIEF REFERENCES:

Aughinbaugh, Selling Latin America, pp. 79-90.

Garcia-Calderon, Latin America, pp. I22-126, I91-200.

Koebel, South A merica, pp. 245-263.

Sweet, History of Latin America, pp. 183, 186-188.

Verrill, Getting Together with Latin America, pp. 130-136, 201-205. 
LONGER Accounts:

Akers, History of South America, pp. r30-196, 554-577.

Dawson, History of South America, vol. ii, pp. 235-347; vol. i, pp. I65-227.

Jones, History of South America, pp. 249-263, 231-248.

Porter, The Ten Republics, pp. 138-I55, 23I-244.

AdDitional References:

Koebel Paraguay.

Walle, Bolivia.

Washburn, The History of Paraguay.

Wright, Bolivia.

C. COURSE OF THE NORTHERN LATIN STATES AND DEPENDENCIES

r. History of the Continental Republics

a. Outline of Mexican Evolution.

(I) The Period of Domestic and Foreign Struggles.

(a) Establishment of the Republic.

i. Mexico: the land and its inhabitants.

ii. Formation and overthrow of the Empire.

iii. Chronic violence: the appearance of Santa Anna.

(b) Conflict with Texas and the United States.

i. The revolt of Texas.

ii. Mexican defeat and Texan independence.

iii. War with the United States: results.

iv. Subsequent financial difficulties in Mexico.

(c) European Intervention and Invasion.

i. European financial interests in Mexico.

ii. Preparations for allied intervention.

iii. The French phase: Empire of Maximilian.

iv. United States diplomacy: overthrow of the Empire. 
(2) Recent Political and Industrial Growth.

(a) Strong Rule and Internal Development.

i. The régime of Juarez: State and Church.

ii. The administration of Diaz, r877-r9r r.

iii. Rise of Mexican credit and prestige.

(b) Return to Political Instability.

i. The revolution of rgro-rg I : cientificos.

ii. Internal disorder and United States intervention.

iii. Recent developments and existing problems.

(c) Social and Economic Conditions.

i. Mexican industries and foreign interests.

ii. Social problems: the peon and the Indian.

\section{BRIEF REFERENCES:}

Aughinbaugh, Selling Latin America, pp. 156-167; (economic).

Cambridge Modern History, vol. x, pp. 676-677.

Sweet, History of Latin America, pp. 202-210.

Verrill, Getting Together with Latin America, pp. 189-193.

\section{LONGER ACCOUNTS:}

Dodd, Modern Constitutions, vol. ii, pp. 37-76; (documentary).

Garcia-Calderon, Latin America, pp. 149-163.

Latane, The United States and Latin America, pp. 193-238, 263-264, 3०7-3Ir.

\section{Additional READINGS:}

Barron, The Mexican Problem.

Enock, Mexico.

Fyfe, The Real Mexico.

MacHugh, Modern Mexico.

Martin, Mexico of the 2oth Century.

Morris, The Story of Mexico.

Reed, Insurgent Mexico.

Winter, Mexico and Her People of Today. 
b. The Central American States.

(I) Evolution of Central American Political Policies.

(a) The Basis of Central American Development.

i. Geographical, soil, and climatic conditions.

ii. Races and social classes represented.

iii. The variety and contrast of conditions.

(b) Collective Development of the Central American States.

i. Composition of the Central American federation.

ii. Character of the government: abuses.

iii. The parting of the ways, 1838 .

(2) Aspects and Results of Separate Development.

(a) Economic and Social Progress.

i. Resources of the Central American states.

ii. Unwise administrations and national debts.

iii. European financial demands: United States anxiety.

(b) Outline of Political Events.

i. Walker's exploits in Nicaragua:

ii. Difficulties with Nicaragua and Honduras after 1906.

iii. Terms of the Nicaraguan treaty of I9I6: protests.

iv. End of the Central American Court of Justice.

v. Attempt at a new Central American federation, I92I-I922.

(c) The Appearance of Independent Panama.

i. Economic basis: the Canal Zone.

ii. Relations with neighboring states: Costa Rica.

iii. Extent of United States intervention: Caribbean policy.

\section{BRIEF REFERENCES:}

Cambridge Modern History, vol. xii, pp. 672-673.

Garcia-Calderon, Latin America, pp. 222-226.

Latané, The United States and Latin America, pp. 280-288.

Sweet, History of Latin America, pp. 210-213. 
LONGER ACCOUNTS:

Aughinbaugh, Selling Latin America, pp. 138-155; (economic).

Jones, Caribbean Interests of the United States, pp. 148-217.

Munro, The Five Republics of Central America, pp. I-163.

Porter, The Ten Republics, pp. I1-15, 92-I10.

Verrill, Getting Together with Latin America, pp. 159-163, 168-171, I82-185, 187-I89, I93-20I, 209-211.

FURTHER READING:

Bishop, Panama, Past and Present.

Domville-Fife, Guatemala and the States of Central America.

Gomez-Villafranca, Costa Rica.

Koebel, Central America.

Martin, Salvador of the 2oth Century.

Winter, Guatemala and Her People of Today.

\section{Island States and Colonies}

a. The West Indian Republics.

(I) Bases of West Indian History.

(a) Physiography of the West Indies.

i. Their volcanic origin: topography.

ii. Climatic, soil, and moisture conditions.

(b) Social conditions and Economic Resources.

i. Racial elements: proportions of negroes.

ii. Natural resources and agricultural adaptation.

(2) The Rise of Haiti and Santo Domingo.

(a) Evolution of the Republic of Haiti.

i. Origin and character of French control.

ii. Revolution under Toussaint L'Ouverture.

iii. Establishment of a negro despotism.

iv. Political distress and United States intervention.

(b) The History of Santo Domingo.

i. Relation to the Haitian Republic.

ii. Wars for independence from Spain and Haiti.

iii. Establishment of the Dominican Republic.

iv. Loss of financial independence. 
(3) A Survey of Cuban Development.

(a) Political Changes in Cuba.

i. Spanish misrule and Cuban revolts.

ii. Liberation and formation of a republic.

iii. Relations with the United States and Europe.

(b) Economic and Social Conditions.

i. Growth of the sugar and tobacco industries.

ii. Progress in education and general culture.

BRIEF REFERENCES:

Garcia-Calderon, Latin America, pp. 226-23I.

Keller, Colonization, pp. 329-34I.

Sweet, History of Latin America, pp. 148-159, 259-264.

Verrill, Getting Together with Latin America, pp. 163-168, 185-187.

LONGER ACCOUN TS:

Aughinbaugh, Selling Latin America, pp. I68-185; (economic).

Jones, Caribbean Interests of the United States, pp. 80-106.

Latané, The United States and Latin America, pp. 83-I43, 276-280, 288-290.

Additional Readings:

Eves, The West Indies.

Filsinger, Exporting to Latin America.

Robinson, Cuba, Old and New.

Schoenrich, Santo Domingo: A Country with a Future.

Verrill, The Book of the West Indies.

- Cuba, Past and Present.

Wright, $C u b a$.

b. Foreign Colonial Possessions in Latin America.

(I) European Colonies on the American Continent.

(a) British Interests in Central America.

i. Origin and extent of British Honduras.

ii. Economic and diplomatic aspects of the colony.

iii. British relations with Nicaragua.

(b) The Guianas in Latin-American History.

i. Early English attempts at colonization.

ii. Activities of the Dutch West India Company. 


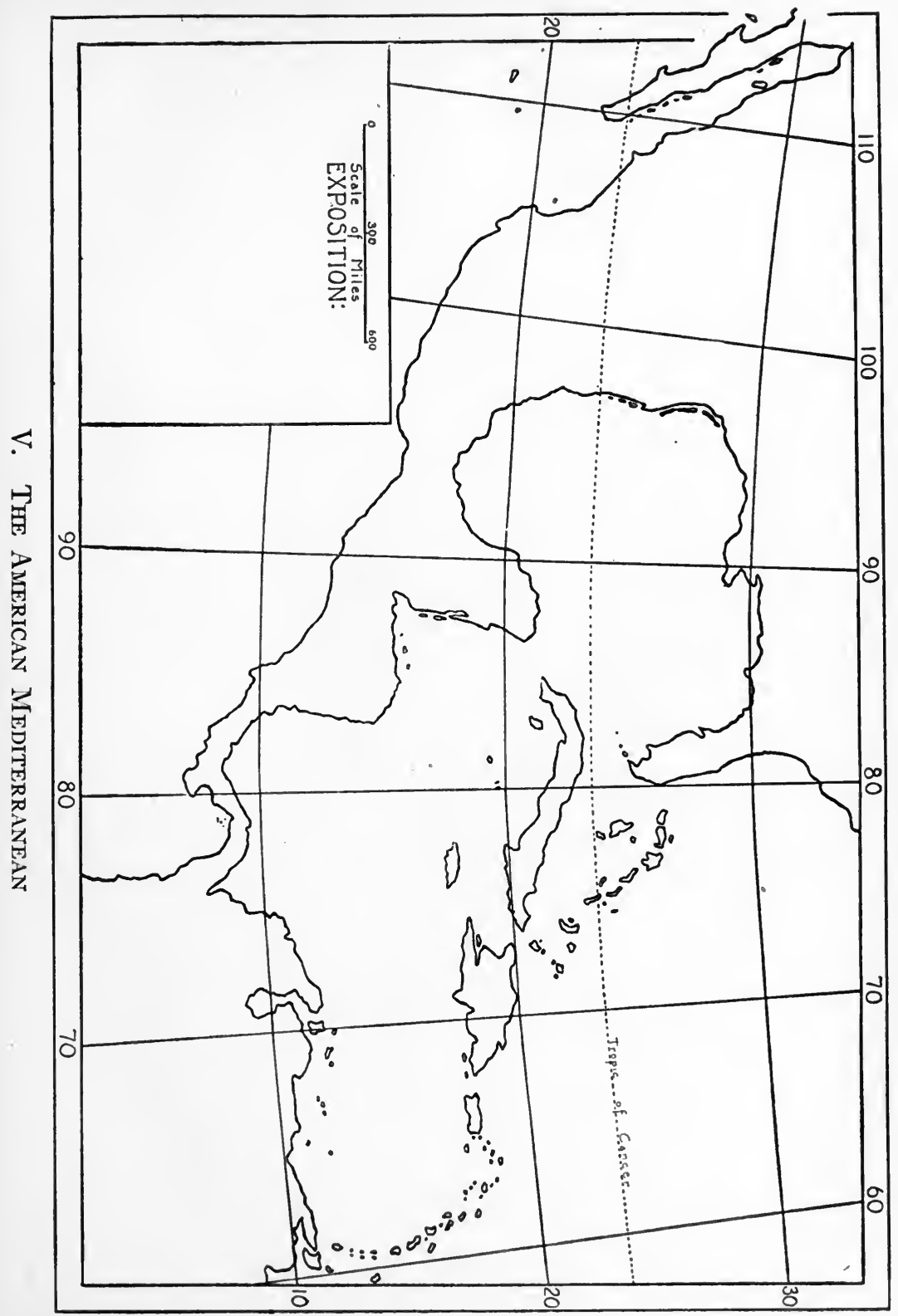


$=$ 
iii. Establishment of French settlements.

iv. Nature of the colonists and their governments.

v. Lack of progress in the Guianas.

(2) Maritime Colonies in the New World.

(a) European Island Colonies.

i. Location and extent of British possessions.

ii. Remaining French holdings.

iii. Extent of the Dutch West Indies.

iv. Miscellaneous colonial holdings: the Falklands.

v. Political and commercial importance of these colonies.

(b) United States Possessions in the Caribbean.

i. History and ownership of Porto Rico.

ii. Political, social and economic conditions.

iii. Purchase of the Danish West Indies.

iv. Political and strategic value of the Virgin Isles.

BRIEF REFERENCES:

Bolton and Marshall, Colonization of North America, pp. I30-132, I66-167, 251-253, 339-342.

Hart, The Monroe Doctrine, pp. 105-106, I 25, I51, 312.

Sweet, History of Latin America, pp. 22, 28.

Verrill, Getting Together with Latin America, pp. I45-I50, I7 I-I74, I80-182.

LONGER ACCOUnTs:

Aughinbaugh, Selling Latin America, pp. I86-21I; (economic).

Jones, Caribbean Interests of the United States, pp. 17-80, 98-106.

Latané, The United States and Latin America, pp. 135, 157-164, 238249, 264, 289-290.

Additional Readings:

Aspinwall, The British West Indies.

Eves, The West Indies.

Hill, Cuba and Porto Rico, with Other Islands.

Koebel, Central America.

Rodway, Guiana: British, French, and Dutch.

Rowe, The United States and Porto Rico.

Westergaard, The Danish West Indies.

Verrill, The Book of the West Indies. 


\section{LATIN-AMERICAN PROBLEMS AND COLLECTIVE DEVELOPMENT}

\section{A. NATIONAL GROWTH OF LATIN-AMERICAN STATES}

\section{Stages in National Evolution}

a. The Age of Dictators, $1826-1852$.

(I) Explanation of the Period.

(a) Causes of the Dictator Phenomenon.

i. The lack of political experience.

ii. Opportunities for usurpation of power.

iii. Absence of foreign contact and restraint.

iv. Limits of the period of dictators.

(b) Characteristic Features of Personal Government.

i. Promulgation of constitutions and promunciamentos.

ii. Government for the privileged.

iii. The attitude of the masses.

iv. Frequency of change of control.

(2) Characteristics and Methods of Dictators.

(a) Usual Traits of the Group.

i. Personal ambition and vanity.

ii. Dependence on military despotism.

iii. Distribution of political spoils.

iv. Their methods of silencing opposition.

(b) Comparison of Typical Dictators.

i. Enlightened despotism of Guzman Blanco.

ii. Paraguay under Francia and Carlos Lopez.

iii. Constructive work of Ramon Castilla.

iv. Rosas and Argentine nationality.

v. Character of the Diaz régime. 


\section{BRIEF REFERENCES:}

Hart, The Monroe Doctrine, pp. 101-105, 245, 249.

Porter, The Ten Republics, pp. II-21.

Munro, The Five Republics of Central America, pp. 24-31.

Shepherd, Latin America, pp. 8I-90.

Sweet, History of Latin America, pp. I78-1 79, 183, 202, 205-208.

\section{LONGer Accounts:}

Bryce, South America, pp. 524-540.

Garcia-Calderon, Latin America, pp. 86-11 7, 196-197.

Jones, South America, pp. I43-154, 20I-206, 231-24I, 268-274, 277282.

\section{Additional Readings:}

Akers, History of South America.

Dawson, History of South America, 2 vols.

Enock, The Republics of South and Central America.

Hayes, Political and Social History of Modern Europe, vol. ii.

Koebel, The History of South America.

Shepherd, The Hispanic Nations of the New World.

b. The Struggle for Political Stability, $1852-1876$.

(I) General Characteristics of the Period.

(a) Rise of Factions and Parties.

i. Causes for rival factions: usual number.

ii. Elements represented in party politics.

iii. Bearing of parties on political stability.

(b) The Character of Political Issues.

i. Predominance of religious and group interests.

ii. Frequent clashes between hostile parties.

iii. Sporadic appearance of dictators.

(2) Outcome of the Transition Period.

(a) Effects of Party Evolution.

i. Partial extension of the franchise: reasons.

ii. Beginning of internal improvements.

iii. Growing strength of the liberal elements. 
(b) Frequent Changes in Form of Government.

i. Numerous changes in New Granada.

ii. Federal tendencies in Venezuela.

iii. Centripetal forces in Argentina.

(c) The Evolution of Brazil.

i. Continued adherence to monarchy.

ii. Gradual and peaceful political development.

\section{BRIEF REFERENCES:}

Bryce, South America, pp. 540-546.

Hart, The Monroe Doctrine, pp. 142-147.

Munro, The Five Republics of Central America, pp. 31-33.

Porter, The Ten Republics, pp. II-23.

Shepherd, Latin America, pp. 90-93.

Sweet, History of Latin America, pp. 165-166, r80-181, 197-199.

\section{LONGER ACCOUnTs:}

Garcia-Calderon, Latin America, pp. 201-248.

Jones, South America, pp. I26-137, I43-154, I87-193, 205-2 13.

\section{Additional ReAdings:}

Akers, History of South America.

Dawson, History of South America, 2 vols.

Enock, The Republics of South and Central America.

Hayes, Political and Social History of Modern Europe, vol, ii.

Koebel, The History of South America.

Shepherd, The Hispanic Nations of the New World.

[Also see histories of individual states.]

c. The Period of National Progress, I876-1922.

(I) General Character of the Recent Period.

(a) Causes for New and Changed Conditions.

i. Growth in political experience.

ii. Partial lessening of economic evils.

iii. Development of natural resources.

iv. Effects of foreign capital and immigration. 
(b) Phases of Political and Social Progress.

i. Rise of a new aristocracy of wealth.

ii. Further extension of popular governmental control.

iii. Improvements in cultural activities.

iv. Interest in social and labor problems.

(2) Brief Survey of Recent Development.

(a) Changes in National Status.

i. Further political changes in Colombia.

ii. Mexican improvements under Diaz.

iii. Establishment of the United States of Brazil.

iv. Significance of the Chilean crisis of r89r.

v. The liberation of Cuba.

(b) Outstanding Results of the Recent Period.

i. General advance and progress in Latin America.

ii. Extension of prestige abroad.

BRIEF REFERENCES:

Garcia-Calderon, Latin America, pp. 235-248.

Porter, The Ten Republics, pp. $2 \mathrm{I}_{-23}$.

Shepherd, Latin America, pp. 93-96.

Sweet, History of Latin America, pp. 214-22 r.

LONGER ACCOUNTS:

Bryce, South America, pp. 546-55 I, 570-580, etc.

Hart, The Monroe Doctrine, pp. 243-256, 302-308, 315-316.

Jones, South America, pp. 134-r 39, etc., 326-340.

Munro, The Five Republics of Central America, pp. 33-49.

\section{Additional Readings:}

Akers, History of South America.

Dawson, History of South America, 2 vols.

Enock, The Republics of South and Central America.

Hayes, Political and Social History of Modern Europe, vol. ii.

Koebel, The History of South America,

Shepherd, The Hispanic Nations of the Nerw World.

[Also see histories of individual states.] 


\section{Political Characteristics of Latin- American States}

a. Types of Latin-American Government.

(I) The Latin-American Conception of Government.

(a) Theories of Democracy and Representation.

i. Latin-American definition of democracy.

ii. Usual bases of representation and suffrage.

iii. Absence of belief in political toleration.

(b) The Attitude toward Constitutional Government.

i. Constitutions as statements of ideals.

ii. Frequent changes in instruments of government.

(c) The Varieties of Latin-American Republics.

i. Instances of centralized government.

ii. Rise of federal republics.

iii. Factors determining the form of government.

(2) Functions and Departments of Government.

(a) The Executive Authority.

i. Methods of presidential nomination and election.

ii. Types and functions of executive councils.

(b) The Legislative Branch.

i. Predominance of the bi-cameral system.

ii. Methods of election: qualifications.

iii. Tendencies toward parliamentary government.

(c) The Judiciary.

i. Usual types and interrelation of courts.

ii. Selection and functions of judges: Roman law.

\section{BRIEF References:}

Hart, The Monroe Doctrine, pp. 248-25I.

Shepherd, Latin America, pp. I41-146.

Sweet, History of Latin America, pp. 214-220.

Verrill, Getting Together with Latin America, pp. I27-128, 132, 140, I $55^{-1} 56$, etc. 
LONGER ACCOUNTS:

Akers, History of South America, pp. 66-70, 95, 115, 118, 125, 226, $3 \mathrm{I} 3,32 \mathrm{I}-324,33 \mathrm{I}-337,4 \mathrm{I} 4-415,418,536-537,555-557,563-564$, $631-632$, etc.

Bryce, South America, pp. 22 I, 344, 423-453.

Dodd, Modern Constitutions, vol. i, pp. 1-30, 149-182, 227-264; vol. ii, pp. $37-76$.

Garcia-Calderon, Latin America, pp. 235-280.

Munro, The Five Republics of Central A merica, pp. 24-49.

Ross, South of Panama, pp. 367-385.

Additional Readings:

Babson, The Future of South America.

Clemenceau, South America Today.

Enock, The Republics of South and Central America.

Shepherd, The Hispanic Nations of the New World.

b. Governmental Policies and Administration.

(I) Government Revenue and National Policy.

(a) Sources of State Funds.

i. Size and location of the burden of taxation.

ii. Kinds of excise taxes and internal revenue.

iii. The tariff as a political issue.

iv. Questions relating to currency and national debts.

(b) Matters of General Policy.

i. Military systems and universal service.

ii. Interest in internal development.

iii. Attitude toward social and religious problems.

(2) Features of Political Activity.

(a) Nature of Political Issues.

i. Government for party interests.

ii. The dominance of financial issues.

iii. Questions of internal improvement.

(b) Party Politics and Alignment.

i. Types of conservative and progressive parties.

ii. Political malcontents and party change.

iii. Religious matters in party organization. 
(c) Political Abuses and Partial Remedies.

i. Relative absence of public opinion: illiteracy.

ii. Kinds and extent of political corruption.

iii. Inefficiency of bureaucratic government.

iv. Election reform: the ballot in Argentina.

BRIEF REFERENCES:

Akers, History of South America, pp. 105, I88-189, 583, 603-604, 632 , etc.

Shepherd, Latin America, pp. I46-I5 I.

Sweet, History of Latin America, pp. 214-215, 217, 218.

Verrill, Getting Together with Latin America, pp. 140, 156, 169-170, I $77,184,203,213$, etc.

\section{LONGER ACCOUNTS:}

Bryce, South America, pp. 358-359, 524-550.

Garcia-Calderon, Latin America, pp. 365-377.

Munro, The Five Republics of Central America, pp. 24-49.

Ross, South of Panama, pp. 331-367.

\section{Additional Readings:}

Dodd, Modern Constitutions, vols. i and ii.

Enock, The Republics of South and Central America.

Clemenceau, South America Today.

Shepherd, The Hispanic Nations of the New World.

[Also see histories of individual republics.]

\section{Latin-American Inter-State Relations}

a. Partial Disintegration and Resultant Problems.

(I) Dissolution of Early Federations.

(a) Centrifugal Tendencies after the Revolutionary Wars.

i. The forces tending toward disintegration.

ii. The question of centralization versus federation.

iii. Character of the states decentralized or disrupted. iv. Impossibility of a United States of South America. 
(b) The Early Disappearance of Great Colombia.

i. Origin and first extent of the state.

ii. Its basis: the individual prowess of Bolivar.

iii. The rise of Venezuela, Ecuador, New Granada.

(c) Decline of the Central American Federation.

i. Formation of the federation, I824-I825.

ii. Elements of discord: inter-state rivalry.

iii. Dissolution of the pact.

iv. Subsequent attempts at federation, e.g.: 1842, I847, I921.

v. Recent inter-state relations: the Court of Justice.

(2) Resolution of Forces in Unstable Political Combinations.

(a) Separation of Santo Domingo and Haiti.

i. Their mutual wars for independence.

ii. The establishment of separate republics: causes.

(b) The Panama-Colombia Controversy.

i. Long standing grievances against Colombia.

ii. Panama's unsuccessful attempts at revolution.

iii. Factors in the revolution of 1903 .

iv. Continuation of strained Colombian relations.

\section{BRIEF REFERENCES:}

Garcia-Calderon, Latin America, pp. 222-226, 347 .

Hart, The Monroe Doctrine, pp. 36-39, 102, 217-223, 324, 333, 346.

Jones, South America, pp. I I 7- I 26, etc.

Latané, The United States and Latin America, pp. 268-276.

Shepherd, Latin America, pp. IоI-ro3.

Sweet, History of Latin America, pp. 148-I49, 155-I56, I80-18r, 2 I0-213.

LONGER ACCOUNTS:

Bullard, Panama, pp. 446-474.

Munro, The Five Republics of Central America, pp. 164-203.

Additional Readings:

Abbot, Panama and the Canal.

Akers, History of South America.

Bunau-Varilla, The Great Adventure of Panama. 
Eder, Colombia.

Enock, The Republics of South and Central America.

Koebel, Central America.

- South America.

Shepherd, The Hispanic Nations of the New World.

b. Aspects of Inter-State Difficulties.

(I) Serious Internecine Wars.

(a) The War against Paraguay, I864-I870.

i. Causes of the war: Francisco Lopez.

ii. The desperate character of the struggle.

iii. Effects on the warring powers.

iv. Disappearance of quarrels in mutual recovery.

(b) The War of the Pacific, I879-1883.

i. Origin of the boundary and political disputes.

ii. The economic basis: nitrates.

iii. Course of the war and Chilean success.

iv. Adjustment of the Tacna-Arica question.

v. Recent phases: submission to the League of Nations.

(2) Non-militant Adjustment of Contentions.

(a) The Use of Arbitration.

i. The Chile-Argentina boundary controversy.

ii. Significance of the Christ of the Andes.

iii. Other settlements by arbitration.

(b) Recent Attempts at Coöperation.

i. Purpose of the A B C alliance.

ii. Latin-American representation at The Hague.

iii. Results of the Washington Peace Conference (I907).

iv. The real status of Pan-Americanism.

(c) Prospects for Future Accord.

i. Existing difficulties: boundary problems, etc.

ii. Extent of militarism and national armaments.

BRIEF RefERENCES:

Bryce, South America, pp. 448-45I.

Cambridge Modern History, vol. xii, p. 687. 


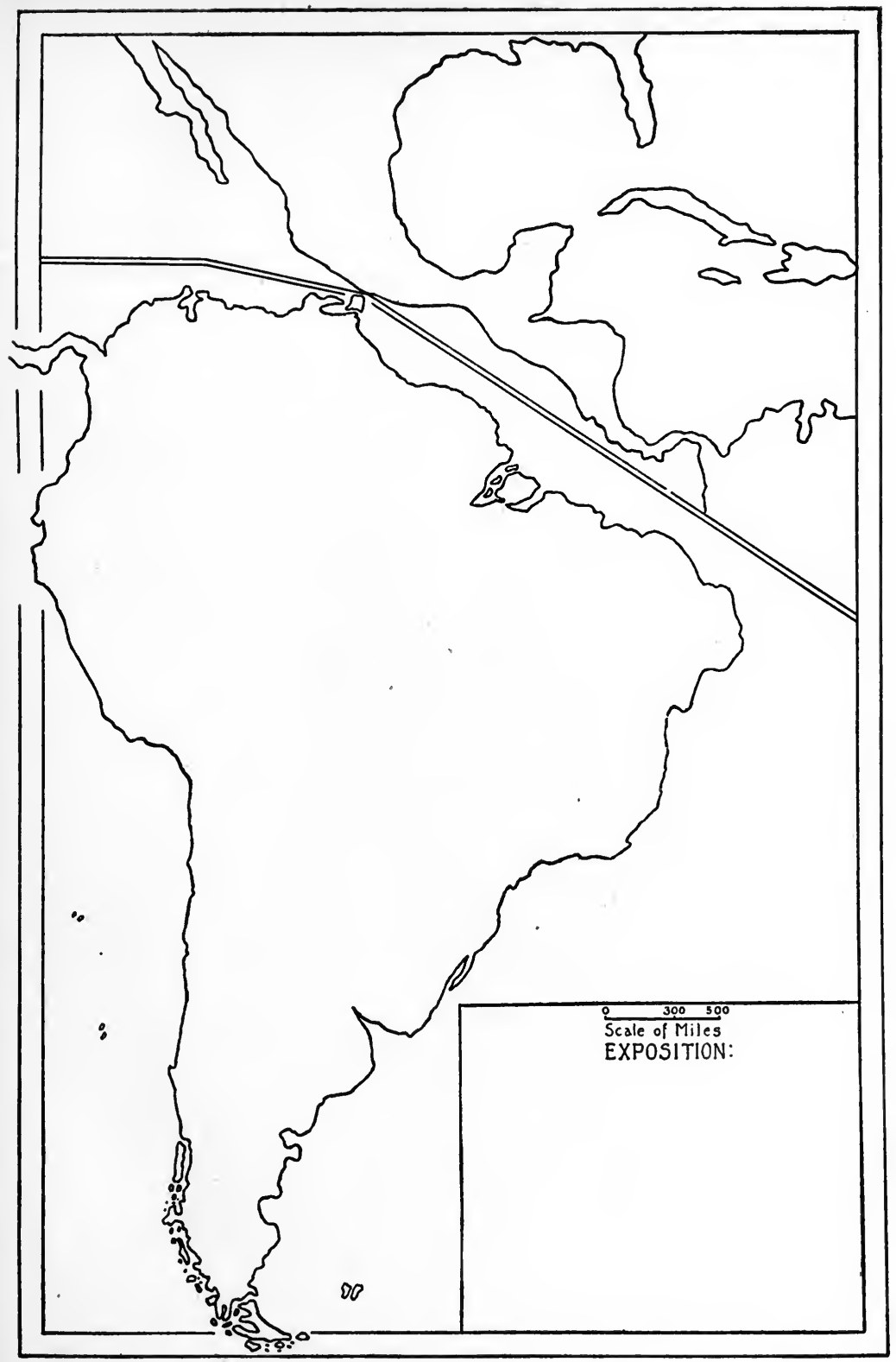

VI. Hispanic-American Political Development 
Garcia-Calderon, Latin America, pp. 196-197, 348-349.

Jones, South America, pp. 24I-246, 308, etc.

Shepherd, Latin America, pp. 96-гог.

Sweet, History of Latin America, pp. I83, I85, etc.

LONGER ACCOUNTS:

Hart, The Monroe Doctrine, pp. 178-180, 251-252, 256, 335, 381-382, 39I, etc.

Latané, The United States and Latin America, pp. 309-319, 329-334.

Munro, The Five Republics of Central America, pp. 204-227.

Additional Readings:

Borchard, The Question of the Pacific.

Calderon-Cousino, Short Diplomatic History of Chilean-Perwian Relations.

Goldsmith, South American Opinions on the War.

Hull, The Hague Conferences.

Kirkpatrick, South America and the War.

Markham, The War between Chile and Peru.

Martua, The Question of the Pacific.

Rocuant, The Neutrality of Chile.

B. CONTEMPORARY LATIN-AMERICAN SOCIAL CONDITIONS

I. Analysis of Latin-American Society

a. The Social Structure.

(r) Racial Elements in the Latin-American Nations.

(a) Racial Composition of Different States.

i. Numerical predominance of the Indian.

ii. Regional distribution of negroes: Brazil.

iii. The "white" states: reasons.

(b) Relative Numbers of Racial Elements.

i. Difficulties of accurate estimation: the census.

ii. Latin-American methods of race determination.

iii. Approximation of numbers and ratios.

iv. Comparison of different sections. 
(c) The Process of Race Amalgamation.

i. Lack of race prejudice: intermarriage.

ii. Types of racial mixtures: characteristics.

iii. Effects of race mingling on national traits.

(2) Latin America as a Racial and Social Laboratory.

(a) The Addition of New Social Elements.

i. Recent waves of immigration.

ii. European countries represented: motives.

iii. The trend of settlement.

(b) Effects of the Extensive Immigration.

i. Relative numbers of the new elements.

ii. Establishment of European group settlements.

iii. Latin-American attitude: immigration inducements.

\section{BRIEF REFERENCES:}

Garcia-Calderon, Latin America, pp. 283-289.

Hart, The Monroe Doctrine, pp. 22-23, 247, 255, 279-28r.

Munro, The Five Republics of Central America, pp. 5-1 I, 21-23. •

Sweet, History of Latin America, pp. 221-226.

\section{LONGER ACCOUNTS:}

Bryce, South America, pp. 454-483, 563-570.

Ross, South of Panama, pp. 139-207.

Shepherd, Latin America, pp. I2 I-I4I.

\section{Additional REAdINGS:}

Adams, Plateau People of South America.

Babson, The Future of South America.

Clemenceau, South America Today.

Neely, South America: Its Missionary Problem.

Palmer, Central America and Its Problems.

Ruhl, The Other Americans.

Shepherd, The Hispanic Nations of the New World.

Speer, South American Problems.

[Also see histories of individual republics.] 
b. Types of Social and Labor Problems.

(I) The Bases of Latin-American Social Strata.

(a) The Higher Social Strata.

i. Political and social dominance of the whites.

ii. Influence of wealth and family in social standing.

iii. Usual identity of political and social positions.

iv. Relation between occupation and social gradations.

(b) The System of Peonage: Origin and Extent.

i. The economic basis for peonage.

ii. Social status and style of life of the peon.

iii. Variations in conditions of peonage.

iv. Forces supporting the system: labor regulations.

(2) The Problems of Social Life.

(a) Housing and Health Conditions.

i. Housing conditions in city and country.

ii. Significance of the death rate: figures.

iii. Rising interest in housing and sanitation.

iv. Important work by Americans: Guayaquil; Panama.

(b) Questions of a Moral Nature.

i. Moral laxity: marriage laws and their abuse.

ii. Increasing prevalence of divorce.

iii. Resultant evils and proposed remedies.

(c) Problems Relating to the Church.

i. Extensive power and influence of the clergy.

ii. Luxury and corruption in the Church.

iii. Exploitation of the ignorant masses.

iv. Movements toward separation of Church and State.

\section{BRIEF REFERENCES:}

Garcia-Calderon, Latin America, pp. 351-364.

Hart, The Monroe Doctrine, pp. 245-248.

Munro, The Five Republics of Central America, pp. 6- 4 .

Shepherd, Latin America, pp. 131-I35, 138-141.

Sweet, History of Latin America, pp. 222-223, 226-228, 234-237. 
LONGER ACCOUNTS:

Bryce, South America, pp. 40, 470-483, 582-587, 589, etc.

Bullard, Panama, pp. 5I I-525.

Ross, South of Panama, pp. 139-230, 299-330.

Additional Readings:

Adams, Conquest of the Tropics.

Babson, The Future of South America.

Clemenceau, South America Today.

Neely, South America: Its Missionary Problem.

Palmer, Central America and Its Problems.

Ruhl, The Other Americans.

Shepherd, The Hispanic Nations of the New World.

Speer, South American Problems.

[Also see histories of individual republics.]

c. Aspects of Latin-American Life and Customs.

(I) Features of Individual Life and Family Character.

(a) The Latin-American Home.

i. Types of buildings: urban and rural.

ii. The position of woman: variations.

iii. Nature of home life: hospitality.

iv. Comparison of classes as to housing and food.

(b) Influence of the Church: Irreligion.

i. General attitude toward religious observances.

ii. Moral instruction and prevalence of immorality.

iii. Tendencies toward religious liberty.

(2) Types of Social Activities.

(a) Latin-American Sports and Diversions.

i. Influence of English, French and American games.

ii. Relative interest in outdoor sports.

iii. Popularity of animal baiting and racing.

(b) Popular Pastimes and Amusements.

i. Prevalence and forms of gambling.

ii. Interest in festivals and carnivals.

iii. The place of the opera. 
(c) Evidences of Latin Temperament.

i. Styles of dress: origin and ostentation.

ii. Characteristics of social etiquette.

iii. Social customs in business.

BRIEF REFERENCES:

Bryce, South America, pp. 175-176, 221-222, 318, 328, 345, 415, 582586.

Munro, The Five Republics of Central America, pp. 7-r4.

Shepherd, Latin America, pp. I35-I4I.

\section{LONGER ACCOUNTS:}

Ballou, Equatorial America, pp. I02-110, 180-188, 231-238, 361-365, etc.; (city conditions).

Ross, South of Panama, pp. 173-207.

Additional Readings:

Ford, Tropical America.

Franck, Vagabonding Down the Andes; etc.

Neely, South America: Its Missionary Problems.

Palmer, Central America and Its Problems.

Ruhl, The Other Americans.

Shepherd, The Hispanic Nations of the New World.

Speer, Missions and Modern History.

\section{Intellectual and Cultural Development}

a. Problems and Progress in Education.

(I) Popular Education in Latin America.

(a) The Educational Problem.

i. Illiteracy: causes and extent (percentages).

ii. Obstacles to popular education: economic and religious.

(b) Progress in Popular Education.

i. Compulsory elementary education laws: results.

ii. Nature and control of secondary schools.

iii. Foreign influences in education. 
(c) Development of Higher Education.

i. Establishment of universities: examples.

ii. Purpose and organization of universities.

iii. Character of advanced work: libraries and equipment.

(2) Achievements in Intellectual Endeavor.

(a) Development in the Arts and Sciences.

i. Beginnings of scientific education.

ii. Industrial and technical instruction.

iii. Progress in educational methods.

(b) Interest in Educational Problems.

i. Establishment of normal schools.

ii. Attempts at rural education.

iii. Evidences of popular interest in education.

iv. Immensity of the educational problem.

BRIEF READINGS:

Ballou, Equatorial America, pp. 121-122, 255-257, 355-356, etc.

Bryce, South America, pp. 575, 579-580.

Munro, The Five Republics of Central America, pp. г1-т2.

Shepherd, Latin America, pp. 192-204.

Verrill, Getting Together with Latin America, pp. 129, 134, I4I, 157, I62, I66, 170, 178, 192, 204, 213-214, 220, etc.

LONGER ACCOUnts:

Akers, History of South America, pp. 41, 123-125, 312-313, 328, 4154I 7, 534-536, 569-570, 607-609, etc.

Moses, South America on the Eve of Emancipation, pp. 143-166.

Ross, South of Panama, pp. 253-298.

AdDitional READINGS:

Babson, The Future of South America.

Brandon, Latin American Universities and Special Schools.

Enock, The Republics of Central and South America.

Palmer, Central America and Its Problems.

Ruhl, The Other Americans.

Shepherd, The Hispanic Nations of the New World.

Speer, South American Problems.

[Also see histories of individual republics.] 
b. Atiainments in General Culture.

(I) Evidences of Public Spirit.

(a) Growth of Charitable Institutions.

i. Treatment of pauperism and delinquency.

ii. Methods of treatment of crime.

iii. Number and nature of public service institutions.

(b) Attempts at Social and Intellectual Instruction.

i. Establishment of public libraries.

ii. Nature and growth of Latin-American journalism.

iii. Characteristic newspapers and magazines.

(2) Advance and Accomplishments in the Fine Arts.

(a) Latin-American Writing and Literature.

i. Origin and development of literary forms.

ii. Foreign influence: e.g., French.

iii. Lines of notable development.

iv. Outstanding names in poetry.

v. Progress in historical and scientific writing.

(b) Evidences of Artistic Capabilities.

i. Achievements in music.

ii. Latin-American painting and sculpture.

iii. Attainments in architecture.

iv. Expression of the artistic impulse.

BRIEF REFERENCES:

Blakeslee, Latin America, pp. 299-306.

Sweet, History of Latin America, pp. 232-324.

LONGER ACCOUNTS:

Bryce, South America, pp. 5I 2-523, 574-580.

Garcia-Calderon, Latin A merica, pp. 249-289.

Koebel, The South Americans, pp. 109-г 3 .

Shepherd, Latin America, pp. 204-250.

Additional Readings:

Bartholomew, A Literary and Historical Atlas of America.

Bierstadt, Three Plays from Argentina.

Calderon, Eight Dramas. 
Coester, The Literary History of Latin America. Hale, The South Americans.

Lamborn, Mexican Paintings and Painters.

Second Pan-American Commercial Conference, Report.

Starr, Readings from Modern Mexican Authors.

Turrell, Spanish-American Short Stories.

c. Evidences of Civic Spirit.

(I) Evolution of Modern Latin-American Cities.

(a) Considerations of Health and Convenience.

i. Civic cleanliness: sewage and water systems.

ii. Improvements in sanitation.

iii. Sources of food supply: markets.

iv. Lighting, policing, and safety precautions.

(b) Traffic and Transportation Facilities.

i. Laws and customs of city traffic.

ii. Vehicles: predominance of motor cars.

iii. Extent of street railway systems.

iv. Ownership of public utilities.

(2) Noteworthy Features of the Latin-American Metropolis.

(a) Beautification of Centers of Population.

i. Cities as expression of life and culture.

ii. Character of streets and boulevards.

iii. Evidences of city planning: park systems.

iv. Influences of European cities: Paris.

(b) Types and Qualities of Civic Structures.

i. Prominence and character of public buildings.

ii. Number and quality of theatres.

iii. Comparison with cities of the United States.

\section{BRIEF REFERENCES:}

Munro, The Five Republics of Central America, pp. 27, 37-40, 66-156.

Porter, The Ten Republics, pp. $68-76$, 124-126, r67-168.

Shepherd, Latin America, pp. 140-14I, I 53, I8r.

Sweet, History of Latin America, pp. 227-228. 


\section{LONGER ACCOUnts:}

Ballou, Equatorial America, pp. 99-102, 128-129, 141-144, 163-177, 218-219, 226-231, 246-248, 252-263, 354-359, etc.

Bryce, South America, pp. 40-54, I 7 I-I86, 210-218, 260-267, 315-324, $35^{1-356,374-386, \text { etc. }}$

Koebel, The South Americans, pp. ro9-1зо.

\section{Additional Readings:}

Blakeslee, Latin America.

Franck, Vagabonding Down the Andes.

Hale, The South Americans.

Mozans, Through South America's Southland.

Peck, The South American Tour.

Ruhl, The Other Americans.

Second Pan-American Commercial Conference, Report.

Van Dyke, Through South America.

\section{LATIN-AMERICAN ECONOMIC AND INDUSTRIAL PROGRESS}

\section{Types of Farming Activities}

a. Plant Industries of the Tropics.

(I) Tropical Plants of Industry.

(a) Characteristics of Tropical Industries.

i. Extent and degree of soil cultivation.

ii. Types of labor and related problems.

(b) The Rubber Industry.

i. Origin of the trade: harvesting methods.

ii. Rapid growth of the rubber trade: value.

(c) Cultivation of Fabric Plants.

i. Extent of cotton production.

ii. Growing importance of flax, hemp, sisal.

(d) Production of Narcotics and Drugs.

i. Areas and relative value of tobacco cultivation.

ii. Varieties and sources of herbs and drugs. 
(2) Commercial Varieties of Food Plants.

(a) Development of the Fruit Industry.

i. Extent of the banana industry: Costa Rica.

ii. Cultivation of citrus fruits.

iii. Methods of packing and shipping: chief markets.

(b) Coffee and Cocoa Production.

i. Areas of growth: Brazil.

ii. Cultivation and harvesting methods.

iii. Commercial value and markets.

(c) Sugar and Allied Industries.

i. Distribution of sugar areas: West Indies.

ii. Cultivation and milling methods.

iii. By-products: value of molasses and rum.

BRIEF REFERENCES:

Filsinger, Exporting to Latin America, pp. 29-3I; (exports).

Munro, The Five Republics of Central America, pp. 14-19.

Shepherd, Latin America, pp. 158-163.

Sweet, History of Latin America, pp. 242-243.

Verrill, Getting Together with Latin America, pp. 136-I37, I4I-I44, г66-г67, г71, 184, г96-т97, 200-201, etc.

FURTHER READING:

Adams, Conquest of the Tropics.

Bartholomew, An Atlas of Economic Geography.

Bureau of Foreign and Domestic Commerce, Special Consular Reports:

Cocoa Production and Trade, No. 50.

Tobacco Trade of the World, No. 68.

Finch and Baker, Geography of the World's Agriculture.

Pearson, The Rubber Country of the Amazon.

[Also see histories of the tropical republics.]

b. Agricultural Development in Temperate Regions.

(I) Factors in Temperate Farming.

(a) The Land Situation.

i. Extent of public lands: homestead acts.

ii. Relation of cheap land to immigration.

iii. Conditions of sale: size of estates (haciendas). 
(b) Aids to Agricultural Extension.

i. State provisions for bounties, loans, etc.

ii. Functions of tariffs and tax exemptions.

iii. Agricultural and farm loan banks.

(2) Character of Agricultural Activities.

(a) Distribution and Extent of Temperate Farming.

i. Dependence on climate and rainfall.

ii. Serious lack of marketing facilities.

iii. Production for local consumption.

iv. Competition between plant and stock farming.

(b) Latin-American Farming Methods.

i. Types of labor: peonage.

ii. The use of domestic animals.

iii. Kinds and quality of farm machinery.

(c) Variety and Importance of Farm Products.

i. Introduction of foreign food plants.

ii. The growing production of cereals.

iii. Relative value of grain exports.

BRIEF REFERENCES:

Filsinger, Exporting to Latin America, pp. 29-3r; (exports).

Shepherd, Latin America, pp. 157-158.

Sweet, History of Latin America, pp. 245-247.

Verrill, Getting Together with Latin America, pp. I29-130, 152-153,

192, 209, 215, etc.

FURTHER READING:

Barrett, South America, the Land of Opportunity.

Bartholomew, An Atlas of Economic Geography.

Bryce, South America: Observations and Impressions.

Bureau of Foreign and Domestic Commerce, Special Agents Series:

Whelpley, Trade Development in Argentina, No. 43.

Wilson, South America as an Export Field, No. 8I.

Finch and Baker, Geography of the World's Agriculture.

Shepherd, The Hispanic Nations of the New World.

South American Yearbook.

Verrill, South and Central American Trading Conditions.

[Cf. histories of the temperate zone states, consular reports, etc.] 
c. Importance of Live Stock Industries.

(I) Extent of the Grazing Business.

(a) Introductory Considerations.

i. Sections adapted to stock raising.

ii. Size of ranches (estancias); $c f$. western United States.

iii. Extent of cattle raising: Argentina.

iv. Varieties of marketable animals.

(b) Factors Contributing to the Grazing Industry.

i. Experiment stations and information bureaus.

ii. Services of national expositions.

iii. Miscellaneous sources of propaganda.

(2) Economic Value of the Animal Industries.

(a) Stock Raising Methods:

i. Introduction of European animal strains.

ii. Live stock breeding: evolution of new types.

iii. Rapid increase in live stock numbers.

iv. Application of scientific stock raising methods.

(b) Relation of Animal Growing to the Foreign Trade.

i. The meat packing industry: methods.

ii. The export and value of raw wool.

iii. The value of hides, tallow, dairy products.

iv. Present tendency of the trade: prices.

BRIEF REFERENCES:

Filsinger, Exporting to Latin America, pp. 29-3I; (exports).

Shepherd, Latin A merica, pp. I54-I55, I63-I65.

Sweet, History of Latin America, pp. 240-242.

Verrill, Getting Together with Latin America, pp. I30, I4I-I42, 215, 22I, etc.

FURTHER READING:

Bartholomew, An Atlas of Economic Geography.

Bryce, South America: Observations and Impressions.

Bureau of Foreign and Domestic Commerce, Special Agents Series: Boots and Shoes in Argentina, Uruguay and Paraguay, No. 30. Tanning Materials of Latin America, No. 28. 
National Foreign Trade Conventions, Proceedings.

Pan-American Commerical Conferences, Reports.

South American Yearbook.

U.S. Commerce Reports, 1918, No. 144: Meat Packing in South A merica.

Verrill, South and Central American Trade Conditions.

Wilcox and Rines, Encyclopedia of Latin America.

[See also histories of individual republics.]

\section{Mining and Manufacturing Conditions}

a. Exploitation of Natural Resources.

(I) Extent and Vaiue of Mineral Wealth in Latin America.

(a) Nitrates and Their Utilization.

i. Nature and uses of nitrates: origin.

ii. Value of the South American fields: Chile.

iii. Methods of mining and shipping.

(b) Stores of Metals and Precious Stones.

i. Extent of deposits of precious metals.

ii. Annual output of silver and gold: Bolivia.

iii. Mining production of the baser metals.

iv. Quality and value of precious stones: Brazil.

(c) Growth of the Oil Industry.

i. Extent and value of oil fields: Mexico.

ii. Attraction of foreign capital.

(d) Factors in Mining Development.

i. Liberal mining concessions and regulations.

ii. Governmental encouragement: machinery importations.

(2) Resources of the Soil.

(a) Potentialities of the Tropics.

i. Unexplored tropical regions: primitive forests.

ii. Possibilities in river transportation.

iii. Extent and value of the logging industry. 
(b) Exploitation of the Soil.

i. Varieties of soil and climatic conditions.

ii. Soil utilization: drainage and irrigation.

iii. Available water power.

BRIEF REFERENCES:

Bryce, South America, pp. 4I-42, 75-76, 202, 207-208, 24I-247, 336, 390-394, 558-560.

Shepherd, Latin America, pp. I56-I57.

Sweet, History of Latin America, pp. 238-240.

Verrill, Getting Together with Latin America, pp. I35-I36, I58, I74, 205, 209, 22I, etc.

FURTHER READING:

Aughinbaugh, Selling Latin America.

Bureau of Foreign and Domestic Commerce:

Commerce Reports, 1918, No. 235: The Mexican Oil Situation.

Simmons, Lumber Markets of the Last Coast of South America; Lum- . ber Markets of the West and North Coasts of South America; Special Agents Series, Nos. II2, I I7.

The Zinc Industry in Mexico; Special Consular Reports, No. 4I, part ii.

Cuevas, The Nitrate Industry.

Miller and Singewald, The Mineral Deposits of South America.

Second Pan-American Commercial Conference, Report.

South American Yearbook.

Wilcox and Rines, Encyclopedia of Latin America.

b. Rise of Manufacturing Industries.

(I) Existing Problems in Factory Development.

(a) The "Sinews" of Manufacturing.

i. Scarcity of capital and skilled labor.

ii. Employment of foreign capital: instances.

iii. Questions of machinery and fuel.

(b) Efforts toward Industrial Independence.

i. Recent interest in water power.

ii. Regulation of duties: high protection.

iii. Government attention to industrial necessities. 


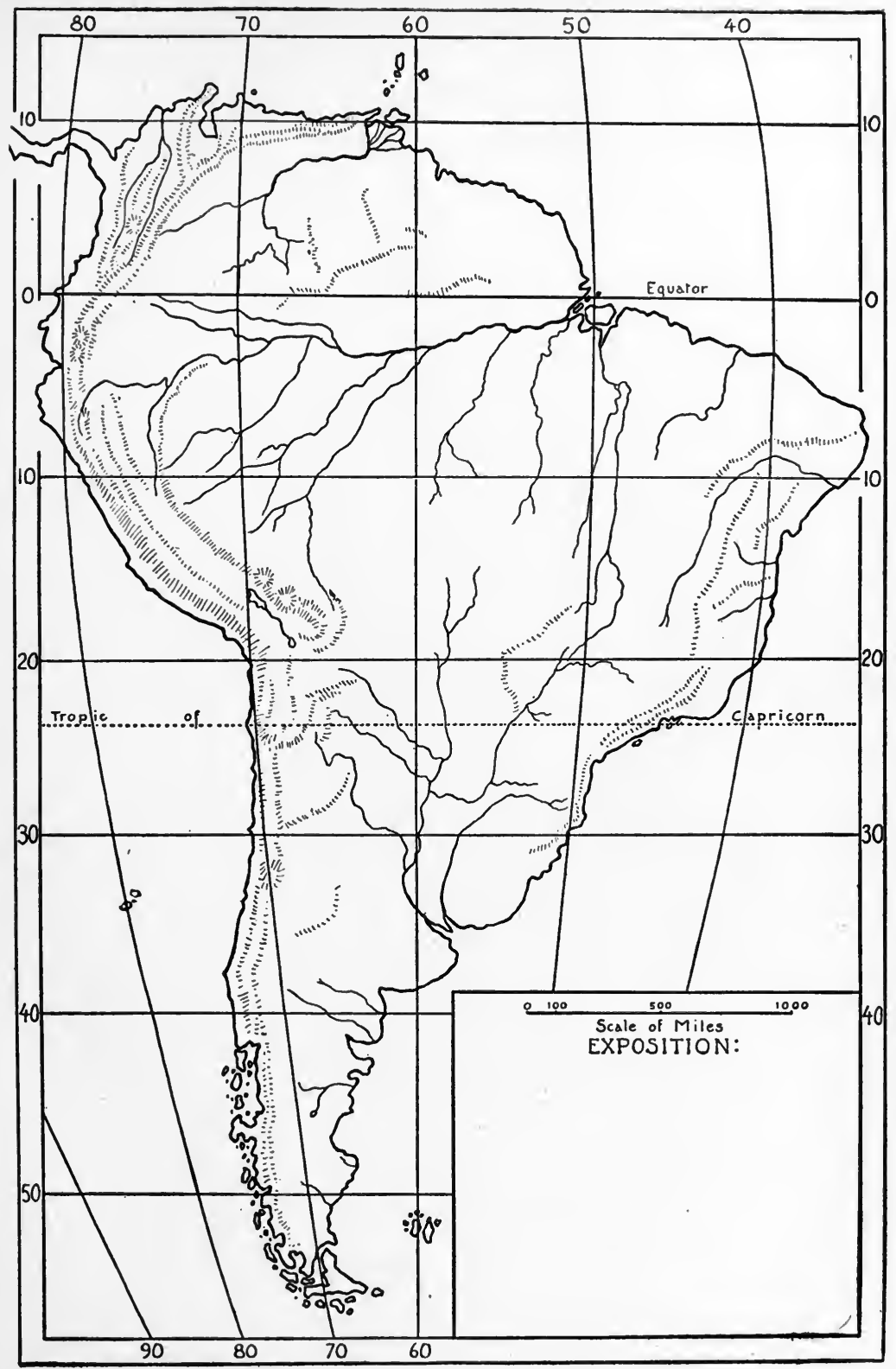

VII. Economic Conditions in South America 

(2) Characteristics of Latin-American Manufactures.

(a) Types of Manufacturing Activity.

i. The appearance of textile factories.

ii. Character of the metal industries.

iii. Manufacture of sugar products.

iv. Packing industries and manufacture of by-products.

v. Fabrication for local needs: the domestic system.

(b) The Relation of Manufacturing and commerce.

i. The tendency toward economic independence.

ii. Relation of manufactures to the staple industries.

iii. Establishment of European and American branch factories.

iv. Absence of manufacturing in the tropics.

v. The present unfavorable balance of trade.

BRIEF REFERENCES:

Bryce, South America, pp. 336, 354, 413, etc.

Munro, The Five Republics of Central America, pp. 15-16.

Shepherd, Latin America, pp. 165-168.

Sweet, History of Latin America, pp. 243-245.

Verrill, Getting Together with Latin America, pp. I 20, 136, I44, I53, 158-159, 167, 179, 192, 215, 221, etc.

Further READING:

Cattell, Foreign Commercial Guide.

National Foreign Trade Conventions, Accounts of Proceedings.

Pan-American Directory.

Proceedings of the International Trade Conference.

Ross, South of Panama.

Snyder, Selling in Foreign Markets.

South American Yearbook.

Verrill, South and Central American Trade Conditions.

Wilcox and Rines, Encyclopedia of Latin America. 


\section{PAN-AMERICANISM AND INTERNATIONAL RELATIONS}

\section{A. EVOLUTION OF AMERICAN POLICIES}

I. Transition Stages of the Monroe Doctrine

a. Early Variations of the Monroe Doctrine.

(I) Corollaries of National Expansion.

(a) The Period of National Realization.

i. Interpretations of the Doctrine from 1823 to 1826 .

ii. Its application to the Falkland Islands case.

iii. Its use in Cuban protection.

iv. Revival of the Doctrine, I844.

(b) The Monroe Doctrine in National Aggression.

i. The Mexican War and Latin-American Attitude.

ii. Formulation of the Polk Doctrine.

iii. The Doctrine in canal negotiations.

iv. Evolution of the Doctrine of American Supremacy.

(2) Growth of the Idea of Intervention.

(a) The French Invasion of Mexico, 1861-1867.

i. Motives and causes for the invasion.

ii. Exposition of the Seward Doctrine.

iii. Withdrawal of French forces: moral effect.

(b) The Doctrine of Paramount Interest.

i. Interest in Cuba: the Virginius affair.

ii. The American Doctrine of Secretary Fish.

iii. Re-application to the Canal question.

iv. American intervention in South America, I88I-1883.

v. Gradual extension of American policy. 


\section{BRIEF REFERENCES:}

Cambridge Modern History, vol. xii, pp. 690-692.

Foster, A Century of American Diplomacy, pp. 454-46r.

Koebel, British Exploits in South America, pp. 156-162.

Sweet, History of Latin America, pp. 263-264.

Tucker, The Monroe Doctrine, pp. 92-107.

\section{LONGER ACCOUNTS:}

Edgington, The Monroe Doctrine, pp. 60-67, 84-127.

Hart, The Monroe Doctrine, pp. 69-182.

Henderson, American Diplomatic Questions, pp. 379-410.

Latané, The United States and Latin America, pp. 193-237.

\section{AdDitional READINGS:}

Burke, A Life of Benito Juarez.

Chadwick, The Relations of Spain and the United States.

Hall, Life of Maximilian $I$.

Hart, The Foundations of American Foreign Policy.

Hoskins, French Attitude toward the Monroe Doctrine and the Mexican Expedition, in The Hispanic American Historical Review, vol. iv, No. 4 (Nov. I92I).

Johnson, America's Foreign Relations (2 vols.).

Rives, The United States and Mexico, I82I-1848 (2 vols.).

Smith, The War with Mexico, I846-I848.

b. Phases of the American Doctrine.

(I) Changes Evoked by the Venezuela Controversy.

(a) Historical Basis of the Dispute.

i. Indefiniteness of old Spanish boundaries.

ii. Issues aroused by the discovery of minerals.

(b) The Course of the Controversy.

i. Efforts toward and failures at agreement.

ii. British rejection of arbitration offers.

(c) Intervention of the United States.

i. Olney's despatch to Great Britain.

ii. Features of the Cleveland-Olney Doctrine.

iii. Peaceful settlement of the matter. 


\section{LATIN-AMERICAN HISTORY}

(2) Recent views of the American Doctrine.

(a) Growing Influence of Caribbean Affairs.

i. Effects of the Spanish-American War.

ii. The Monroe Doctrine at The Hague.

iii. The Panama Canal in American theories.

iv. Evolution of an American Caribbean Policy.

(b) Doctrinal Pronouncements of Recent Administrations.

i. New Features in the Roosevelt Doctrine.

ii. Significance of the Magdalena Episode (I9I2).

iii. The Wilson idea of American relations.

(c) The World War and the American Doctrine.

i. Effect of participation in European conflicts.

ii. The Monroe Doctrine and the League of Nations.

iii. Outgrowths of The Washington Peace Conference (1921-1922).

\section{BRIEF REFERENCES:}

Cambridge Modern History, vol. xii, pp. 687-689.

Foster, A Century of American Diplomacy, pp. 467-475.

Jones, Caribbean Interests of the United States, pp. I-I7.

Shepherd, Latin America, pp. 104-105.

Tucker, The Monroe Doctrine, pp. I16-132.

\section{LONGER ACCounts:}

Edgington, The Monroe Doctrine, pp. I28-I43, I59-205.

Hart, The Monroe Doctrine, pp. 183-242.

Jones, History of Latin America, pp. 323-353.

Latané, The United States and Latin America, pp. 238-260, 320-334.

\section{AdDitional ReAdings:}

Fish, American Diplomacy.

Goldsmith, South American Opinions on the War.

Hall, The Monroe Doctrine and the Great War.

Johnson, America's Foreign Relations (2 vols.).

Kirkpatrick, South America and the War.

Moore, Principles of American Diplomacy. 
2. The Caribbean Policy of the United States

a. The Isthmian Canal and Its Problems.

'I) History of Isthmian Canal Projects.

(a) Early Plans for a Canal.

i. Influence of the Suez Canal.

ii. Formation and failure of a French company.

(b) Anglo-American Relations Respecting the Canal.

i. British claims to interest in a canal.

ii. English attempts to secure a canal route.

iii. The Clayton-Bulwer Treaty, 1850 .

iv. Later changes in American and British attitude.

v. The Hay-Pauncefote Treaty, I90I.

(2) Construction and Significance of the Canal.

(a) Acquisition of the Canal Zone.

i. The treaty with Colombia, 1846 .

ii. Survey and choice of canal routes.

iii. Purchase of French canal shares.

iv. The Panama Revolution.

v. The subsequent canal treaty.

(b) Importance of the Inter-Oceanic Canal.

i. The task of completing the Canal.

ii. Its commercial and strategic value.

iii. Other practicable canal routes: Nicaragua.

iv. The question of canal tolls.

v. The relation to Latin-American and European affairs.

BRIEF REFERENCES:

Cambridge Modcrn History, vol. xii. pp. 685-686, 698-699.

Edgington, The Monroe Doctrine, pp. 68-83.

Filsinger, Exporting to Latin America, pp. 306-309; (commercial).

Foster, A Ccntury of American Diplomacy, pp. 456-458, 46I-467.

Sweet, History of Latin America, pp. 258-259. 
LONGER ACCOUnts:

Bryce, South America, pp. I-36; (descriptive).

Bullard, Panama, pp. 397-445, 475-593; (descriptive).

Jones, Caribbean Interests of the United States, pp. 148-229.

Latané, The United States and Latin America, pp. 144-192, 268-276.

Tucker, The Monroe Doctrine, pp. 43-76.

\section{Additional Readings:}

Abbot, Panama and the Canal.

Bunau-Varilla, The Great Adventure of Panama.

Forbes-Lindsay, Panama and the Canal Today.

Hutchinson, The Panama Canal and International Trade Competition.

Williams, Anglo-American Isthmian Diplomacy.

b. Hegemony of the United States in Central America.

(I) Political and Economic Conditions in Central America.

(a) Survey of the Prevailing Political Situation.

i. Contrasts in political stability.

ii. Political results of economic improvement.

(b) Financial and Economic Burdens.

i. Relative size of national debts: $c f$. Honduras.

ii. Corruption in financial administration: railroads.

iii. Instances of bankruptcy: European liability.

iv. Recent tendencies toward solvency.

(2) United States Aid and Intervention.

(a) American Funding of Debts.

i. Loans and investments in Costa Rica.

ii. Appeals from Honduras and Salvador.

iii. American funds in Guatemala.

(b) Establishment of the Nicaraguan Protectorate.

i. Financial aid to Nicaragua.

ii. Terms of the treaty of r9r6.

iii. Consequent difficulties with neighboring states. 
(3) The Central American Policy of the United States.

(a) United States Interests in Central America.

i. Identity of economic control and political influence.

ii. Direction of United States imperialism: canal interests.

iii. The field for business and commercial expansion.

(b) Characteristic Questions of Future Policy.

i. Extent of moral and political responsibility.

ii. Degree of intervention for justice and order.

iii. Attitude of South American states; e.g., Colombia.

\section{BRIEF REFERENCES:}

Cambridge Modern History, vol. xii, pp. 689-691.

Edgington, The Monroe Doctrine, pp. 60-64.

Shepherd, Latin America, pp. 104-ז06.

Sweet, History of Latin America, pp. 257-259.

Tucker, The Monroe Doctrine, pp. 37-42.

\section{LONGER ACCOUNTS:}

Hart, The Monroe Doctrine, pp. 317-336.

Jones, Caribbean Interests, pp. 17-33, I48-193.

Latané, The United States and Latin A merica, pp. 261-29r.

Munro, The Five Republics of Central A merica, pp. 227-264, 303-320.

AdDitional ReAdings:

Borchard, The American Mediterranean.

Fish, American Diplomacy.

Hodges, The Doctrine of Intervention.

Moore, Principles of American Diplomacy.

Palmer, Central America and Its Problems.

c. American Interests in the West Indies.

(I) Features of the Spanish-American War.

(a) Interest of the United States in Cuba.

i. Strategic position and trade opportunities.

ii. American indignation at Cuban oppression. 
(b) The Causes of the War with Spain.

i. Resolution of the United States Congress.

ii. Fruitless negotiations with Spain.

iii. Effects of American filibustering expeditions.

iv. Destruction of the battleship Maine.

(c) Phases of the Spanish War.

i. Decisive victories of American forces.

ii. The occupation of Porto Rico.

iii. Terms of the final settlement.

2) Recent Expansion of American West Indian Interests.

(a) Extent of Political and Economic Control.

i. Guarantee of Cuban independence: the Platt Amendment.

ii. Subsequent intervention in Cuban affairs.

iii. The Exploitation of Porto Rico.

iv. The Haitian and Dominican "protectorates."

v. Purchase of the Virgin Islands.

(b) Reaction on Latin-American Attitude.

i. Effect of expansion on the Monroe Doctrine.

ii. Latin-American interpretation of developments.

\section{BRIEF REFERENCES:}

Cambridge Modern History, vol. xii, pp. 696-698.

Foster, A Century of American Diplomacy, pp. 458-459.

Garcia-Calderon, Latin America, pp. 313-322.

Hart, The Monroe Doctrine, pp. 337-348.

Sweet, History of Latin America, pp. 259-26r.

Tucker, The Monroe Doctrine, pp. 77-9r.

LONGER ACCOUNTS:

Jones, Caribbean Interests of the United States, pp. 17-33.

Henderson, American Diplomatic Questions, pp. 359-378.

Latané, The United States and Latin America, pp. 83-143, 26I-29I, 328-329. 
Additional Readings:

Borchard, The American Mediterranean.

Chadwick, The Relations of the United States and Spain.

Fish, American Diplomacy.

Johnson, America's Foreign Relations.

MacCorkle, The Monroe Doctrine in Its Relation to the Republic of Haiti.

Moore, Principles of American Diplomacy.

Robertson, The Beginnings of Spanish-American Diplomacy.

Rowe, The United States and Porto Rico.

Schoenrich, Santo Domingo: A Country with a Future.

3. Recent Theories of Latin-American Relations

a. European Attitude toward the American Doctrine.

(I) Basis of the European Point of View.

(a) European Theories of American Relationships.

i. Attitude toward the doctrine of American isolation.

ii. Reception of the original Monroe Doctrine.

iii. The subsequent practice of "watchful waiting."

(b) European Interests in America.

i. Existence of European colonies in America.

ii. Investment of capital in Latin America.

iii. Growth of business and commercial relations.

iv. The bonds created by European migration.

v. Effects of excess population in Europe.

(2) Testing and Eventual Acceptance of the American Policy.

(a) Instances of Attempted Infringement.

i. Cases of joint European action: I823, I86r.

ii. Definite withdrawal of France and Spain.

iii. Subsequent British aggressions.

iv. Recent attitude of Germany and Japan.

(b) Evidences of Dislike and Distrust.

i. Effect of United States colonial expansion.

ii. Hostility displayed by European statesmen: instances.

iii. Attitude of European publicists: the press. 
(c) Partial Recognition of the American Policy. i. Understandings with the United States on Latin America.

ii. Treaty recognition: the Hague (I899) and Versailles (I9I9).

\section{Brief ACcounts:}

Covenant of the League of Nations, Art. 21.

Garcia-Calderon, Latin America, pp. 290-297, 323-331.

Hague Convention, Procés-verbaux, pt. i, p. 69 (1899); Actes et documents, vol. i, p. 335 (1907).

Latané, The United States and Latin America, pp. 222-223, 238-255,

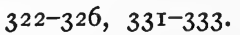

Sweet, History of Latin America, pp. 253-255.

\section{LONGER ACCOUNTS:}

Edgington, The Monroe Doctrine, pp. I33-143, 267-289.

Hall, The Monroe Doctrine and the Great War.

Hart, The Monroe Doctrine, pp. 269-298.

Henderson, American Diplomatic Questions, pp. 4I I-450.

\section{Additional Readings:}

Bigelow, American Policy: the Western Hemisphere in Its Relation to the Eastern.

Fullerton, Problems of Power.

Hodges, The Doctrine of Intervention.

Johnson, America's Foreign Relations.

Latané, America and Britain.

Powers, America Among the Nations.

Reddaway, The Monroe Doctrine.

b. The Latin-American Doctrine.

(I) Latin-American Views of the Monroe Doctrine.

(a) Changes in Latin-American Attitude.

i. Favorable reception of the first pronouncement.

ii. Growth of general dislike of the doctrine.

ii. Opinions of representative Latin-Americans. 
(b) Reasons for Latin-American Hostility.

i. Denial of Latin-American equality.

ii. Lack of voice in all-American affairs.

iii. Disregard of Latin-American abilities.

(c) Substitutes for the American Doctrine.

i. Trial and failure of Pan-American congresses.

ii. Evolution of the A B C combination.

iii. Evidences of a Latin-American sentiment.

(2) Proposed Changes in the American Doctrine.

(a) The Calvo Doctrine (1867).

i. Definition of the rights of individuals.

ii. The doctrine of diplomatic intervention.

iii. Its relation to the Monroe Doctrine.

(b) The Drago Doctrine (1902).

i. Definition of the bases for foreign intervention.

ii. The use of force and of arbitration.

iii. Relation to previous doctrines.

(c) Latin America and the Great War.

i. Grouping of Latin-American states on war issues.

ii. Significance of the attitude shown.

iii. Latin America and the League of Nations.

BRIEF REFERENCES:

Bryce, South America, pp. 507-512.

Cambridge.Modern History, vol. xii, p. 70 .

Latané, The United States and Latin America, pp. 312-319.

Shepherd, Latin America, pp. I02-IO4.

Sweet, History of Latin America, pp. 265-266.

Verrill, Getting Together with Latin America, pp. I-I2.

LONGER ACCOUNTS:

Edgington, The Monroe Doctrine, pp. 218-266.

Garcia-Calderon, Latin America, pp. 335-350, 387-400.

Hart, The Monroe Doctrine, pp. 243-268.

Martin, Latin America and the War; League of Nations, vol. ii, pp. 227270. 


\section{Additional Readings:}

Bingham, The Monroe Doctrine; an Obsolete Shibboleth.

Hall, The Monroe Doctrine and the Great War.

Kirkpatrick, South America and the War.

Moore, Principles of American Diplomacy.

Reyes, The Two Americas.

c. Pan-Americanism.

(I) Early Pan-American Projects.

(a) Origin of the Idea.

i. Official suggestions, I822-1825.

ii. Efforts of John Quincy Adams.

iii. Provisions for a congress at Panama (1826).

iv. Unfavorable response and failure.

(b) Revival of Pan-American Plans.

i. Discussions and proposals in 1878 .

ii. Plans for a congress at Washington, r889.

iii. Attendance and sessions of the meeting.

iv. Its resolutions and lasting accomplishments.

(2) Recent Attempts at Pan-American Realization.

(a) Continuation of International American Conferences.

i. Review of the Mexican Conference, Igor.

ii. Work of the Third Conference (I906); treaties.

iii. Estimation of the Fourth Congress (I9ro).

(b) Accomplishments of Subsidiary Bodies.

i. Labors of the Pan-American Union.

ii. Work of recent financial congresses.

(c) The Status of Inter-American Relations.

i. The ideas and theories of Pan-Americanism.

ii. Reasons for the paucity of results.

iii. Prospects for future accord and coöperation.

BRIEF REFERENCES:

Cambridge Modern History, vol. xii, p. 700; (Panama Congress).

Foster, A Century of American Diplomacy, pp. 451-454; (Panama Congress). 


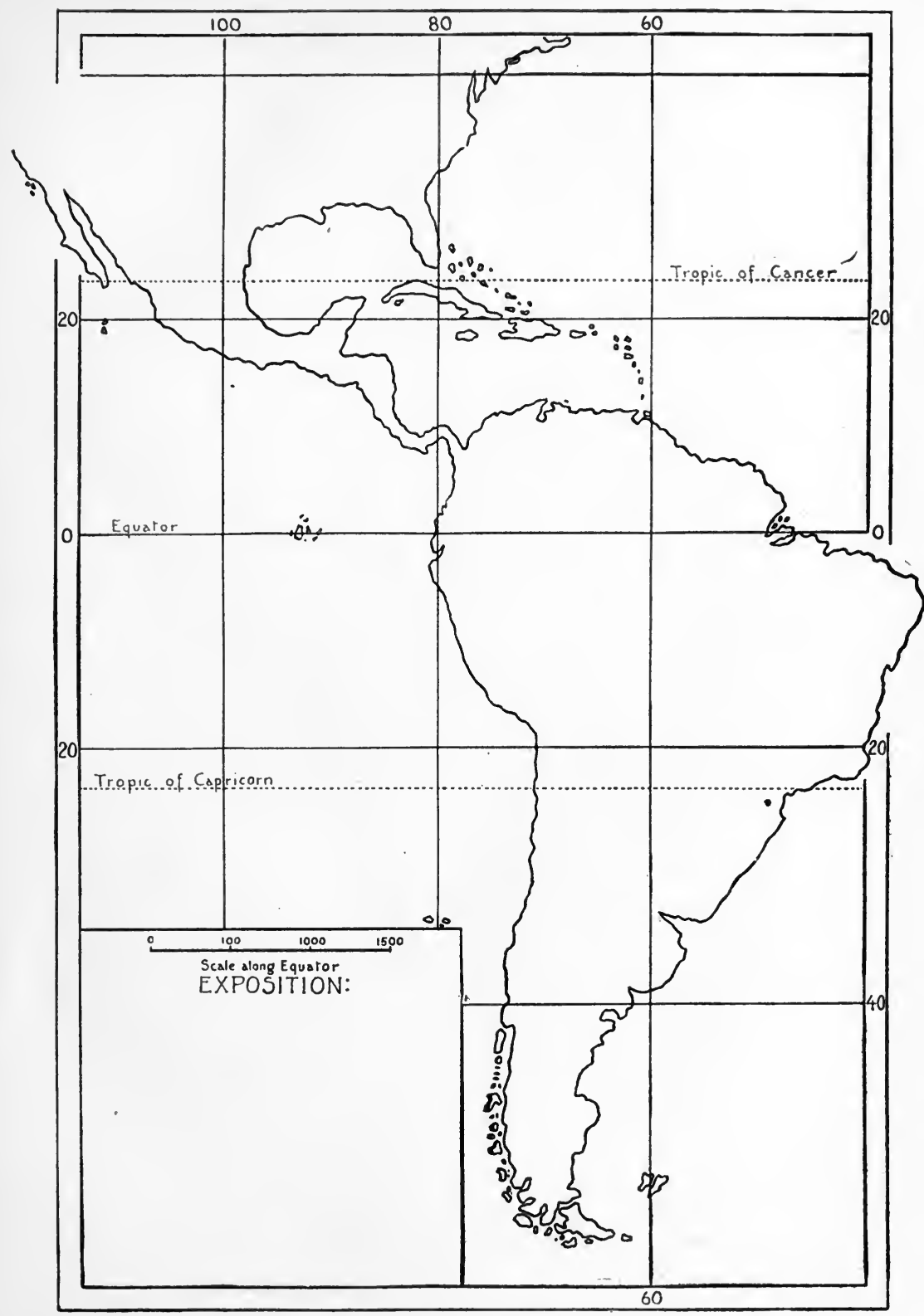


, 
Henderson, American Diplomatic Questions, pp. 342-358; (Panama Congress).

Shepherd, Latin America, pp. 99, 104-106.

Sweet, History of Latin America, pp. 267-269.

Tucker, The Monroe Doctrine, pp. 23-36; (Panama Congress).

\section{LONGER ACcounts:}

Edgington, The Monroe Doctrine, pp. 55-59, 206-21 7, 290-314.

Filsinger, Exporting to Latin America, pp. 334-346; (Pan-American commercial relations).

Hart, The Monroe Doctrine, pp. 349-403.

Latané, The United States and Latin America, pp. 292-319.

Munro, The Five Republics of Central America, pp. 204-226.

Verrill, Getting Together with Latin America, pp. 108-124.

\section{Additional Readings:}

Barrett, Pan-America and Pan-Americanism.

Chadwick, Pan-American Congresses.

Hall, The Monroe Doctrine and the Great War.

Hull, The Monroe Doctrine: National or International?

Root, Miscellaneous Addresses.

Usher, Pan-Americanism.

[See also the Bulletins of the Pan-American Union.]

\section{B. FOREIGN BUSINESS AND TRADE RELATIONS}

\section{Factors in Latin-American Trade Development}

a. Monetary and Banking Conditions.

(I) Survey of Latin-American Monetary Systems.

(a) Nature of the Coinage.

i. Units and standards of value.

ii. Usual small circulation of coin.

(b) Character of the Currency.

i. Wide variations in monetary systems.

ii. Extent and value of paper currency.

iii. Causes of wide fluctuations. 
(2) The Banking Situation.

(a) Latin-American Financial Methods.

i. Government finance: indebtedness and solvency.

ii. Bond issues and speculation.

iii. Corporation financing methods: exchanges.

(b) Influence of Foreign Banks.

i. European dominance of finance.

ii. Number and size of Latin-American banks.

iii. Kinds of banking activities.

(c) American Banking Opportunities.

i. Reasons for European banking success.

ii. Comparison of European and American methods.

iii. Unusual opportunities for capital.

iv. Establishment of United States branch banks: instances.

\section{BRIEF REFERENCES:}

Aughinbaugh, Selling Latin America, pp. 288-310.

Cambridge Modern History, vol. xii, 692-694.

Garcia-Calderon, Latin America, pp. 378-386.

Shepherd, Latin America, pp. I 50-I 53, I68-i69.

Longer AcCounts:

Filsinger, Exporting to Latin America, pp. 213-227, 504-5 Io.

Munro, The Five Republics of Central America, pp. 284-302.

Verrill, Getting Together with Latin America, pp. I26, I30, 137, 146, I50, 154, 159, 163, 168, I75, 190, 198, 202, 212, 217, etc.

Additional Readings:

Cosby, Latin American Monetary and Exchange Conditions.

Publications of the Bureau of Foreign and Domestic Commerce:

Commerce Reports, 1919, No. 27; The New Banking Law of the Republic of Mexico.

Hurley, Banking and Credit in Argentina, Brazil, Chile, and Peru. Special Agents Series, No. 9o.

Lough, Financial Developments in South American Countries. Special Agents Series, No. Iо3.

Wolfe, Foreign Credits. Special Agents Series, No. 62. 
b. Latin-American Business Methods.

(I) Types of Business Enterprises.

(a) Methods of Merchandising.

i. Wholesale and retail establishments.

ii. Markets and fairs.

iii. Use of the metric system.

(b) Foreign Influence in Business Affairs.

i. Foreign capital in "big business."

ii. Activities of trusts and monopolies.

(2) Important Business Customs.

(a) The Conduct of Business.

i. Trade loyalty, reliability, and efficiency.

ii. Politeness and hospitality in business.

iii. The value of personal contact.

iv. Latin-American business ethics.

(b) Legal Conditions in Latin America.

i. The predominance of Roman law.

ii. Variation of laws: mining regulations.

(c) Relation of Politics and Business.

i. Irregular practices of legal authorities.

ii. Necessity for commercial registration.

iii. Avenues of approach to business firms.

iv. Extent and value of state contracts.

BRIEF REFERENCES:

Filsinger, Exporting to Latin America, pp. 44-56, 124-1 36 .

Shepherd, Latin America, pp. 169-1 73 .

Verrill, Getting Together with Latin America, pp. 28-55.

FURTHER READING:

Aughinbaugh, Selling Latin America.

Commercial Laws of the World (Boston, 1917).

Cooper, Understanding South America.

Cosby, Latin American Monetary and Fachange Conditions. 
Savay, Principles of Foreign Trade.

U.S. Commerce Reports, I918, No. 286: Credit Terms in Latin America. Verrill, South and Central American Trade Conditions.

[See also consular reports, histories of individual states, etc.]

c. Features of Latin-American Commercial Regulation.

(I) Tariff Systems in Latin America.

(a) The Basis of Latin-American Tariffs.

i. Governmental policies of protection.

ii. Difference between theory and practice.

(b) The Operation of Tariff Regulations.

i. Variations in rates and articles taxed.

ii. The use of surtaxes and exemptions.

iii. The trial of preferential tariffs: Brazil.

iv. Methods used in examining goods.

(2) Customs and Regulations Affecting Foreign Trade.

(a) Prevailing Trade Mark Laws.

i. Means of registration of trade marks.

ii. Frequent exploitation of foreign firms.

iii. Necessary precautions of American exporters. iv. The nature of copyright laws.

(b) The Importance of Trade Marks in Latin America.

i. The danger of infringement and competition.

ii. Trade values of design, color, etc., in trade marks.

(c) Government Trade Regulations.

i. Requirements in packing and marking of goods.

ii. Kinds and details of commercial papers required.

iii. Extent of supervision of imports and exports.

\section{BRIEF REFERENCES:}

Munro, The Five Republics of Central America, pp. 265-282. Shepherd, Latin America, pp. I73-174. 
LONGER ACCOUNTS:

Aughinbaugh, Selling Latin America, pp. 266-287.

Cattell, Foreign Commercial Guide.

Filsinger, Exporting to Latin America, pp. 15I-200, 228-238, 287-296, $520-522$.

Verrill, South and Central American Trade Conditions.

Bureau of Foreign and Domestic Commerce:

Tariff Series, Nos. 24, 24A, 24B, Consular Regulations of Foreign Countries (rev. ed.).

No. 31, Registration of Trade-Marks in Latin America.

No. 34, Tariff Systems of South American Countries.

Miscellaneous Series, No. 7, Factors in Foreign Trade.

[See also histories of individual states, yearbooks, etc.]

d. Problems of Internal Communication and Transportation.

(I) Characteristics of Overland Transit.

(a) Survivals of Colonial Conditions.

i. Sectional lack of progress in transportation.

ii. Extensive use of Indian and animal carriers.

iii. Nature of mountain and provincial roads.

iv. Difficulties in overland trade.

(b) Recent Introduction of Rapid Communication.

i. Use of the telegraph, telephone and wireless.

ii. Interest in commercial aviation.

(2) Development of Steam Transportation.

(a) The Value of Inland Waterways.

i. Territories penetrated by navigable rivers.

ii. Cost and relative safety of river transportation.

iii. Character of river and lake boats: speed and capacity.

(b) Coming of the Era of Railways.

i. Origin of railway programs: sources of capital.

ii. Areas opened to railway facilities: total mileage.

iii. The proportion of local and trunk lines. 
(c) Character of Railway Policies.

i. State and private ownership of roads.

ii. Prevailing passenger and freight rates.

iii. Politics in railway construction.

iv. Pan-American railway projects.

BRIEF REFERENCES:

Bullard, Panama, pp. 4I8-430; (Panama Railroad).

Filsinger, Exporting to Latin America, pp. I18, I56, I86-187.

Garcia-Calderon, Latin America, pp. 381-386.

Shepherd, Latin Amcrica, pp. I 79-189.

Sweet, History of Latin America, pp. $247^{-2} 5^{\mathrm{I}}$

\section{Additional Readings:}

Bryce, South America; (fragmentary and descriptive).

Cattell, Foreign Commercial Guide.

Directory of Latin America.

Exporter's Encyclopedia.

Export Trade Directory.

Halsey, Railways of South and Central Amcrica.

South American Yearbook.

Verrill, Getting Together with Latin America.

[See also, Bureau of Foreign and Domestic Commerce, Special Agents Series, Nos. I, 5, 8, 9, r6, I9, 21, 22; guides to Central and South America; histories of individual states, etc.]

e. Shipping and Port Facilities.

(I) Shipping Lines in Latin-American Service.

(a) Extent of the Latin-American Merchant Marine.

i. Absence of large shipping companies.

ii. Ownership of the vessels in the coastal trade.

iii. Native boats in river service.

(b) Foreign Control of Latin-American Trade.

i. European monopoly of the carrying trade.

ii. Pre-war lines to Latin America.

ii. Ports of call and points of transshipment. 
(c) Revival of the United States Merchant Marine.

i. Effects of the Great War on United States Shipping.

ii. Partial recovery of the American commercial fleet.

iii. Lines in Latin-American Service.

(2) Latin-American Terminal Conditions.

(a) Harbors and Port Development.

i. Location of principal Latin-American ports.

ii. Dock and warehouse facilities.

iii. Efforts toward and expense of harbor improvements.

(b) The Use of Open Roadsteads.

i. Harbor handicaps of the Pacific Coast.

ii. Dependence on lighterage service.

iii. Dangers and drawbacks of the system.

BRIEF REFERENCES:

Bullard, Panama, pp. 588-590; (Canal shipping).

Filsinger, Exporting to Latin America, pp. 310-313, 516-520.

Shepherd, Latin America, pp. 189-191.

Sweet, History of Latin America, pp. 269-27I.

Verrill, Getting Together with Latin America, pp. 95-107, I33-I34, I49150, 156-157, 165-166, 177-178, 199-200, 214-215, etc.

Additional Readings:

Cattell, Forcign Commercial Guidc.

Exporter's Encyclopedia.

Export Trade Directory.

Filsinger, Trading with Latin America.

Pan-American Directory.

Pepper, American Foreign Trade.

Snyder, Selling in Foreign Markets.

Bureau of Foreign and Domestic Commerce, Special Agents Series:

Hutchinson, Trade Conditions in Brasil; Trade Conditions in Argentina, Uruguay and Paraguay; Trade Conditions in Central America and on the West Coast of South America, Nos. I, 8, 9.

Sheridan, Transportation Rates to the West Coast of South America, No. 72 . 


\section{Survey of United States Business Relations}

a. Beginnings of Economic Penetration.

(I) Factors Controlling the Latin-American Trade.

(a) History of the Trade with Latin America.

i. Colonial and early national commercial intercourse.

ii. Reasons for trade decline.

(b) Causes for Renewed Commercial Interest.

i. Rise of United States industries: market needs.

ii. Demands for raw materials.

iii. Recovery of the merchant marine: war effects.

iv. Results of changing political relations.

(c) Present Status of the American Trade.

i. Steamship lines and shipping facilities.

ii. Extent of trade growth: statistics.

(2) Present Degree of Economic Penetration in Latin America.

(a) United States Investments in Latin America.

i. Extension of Government aid and support.

ii. Private capital in Latin-American industries.

iii. Comparison of American and European investments.

(b) Latin America as an American Market.

i. Establishment of United States export agencies.

ii. Expansion of banking institutions: instances.

iii. General interest in the Latin-American field.

(c) Extent of European Commercial Relations.

i. Statistics on the European trade.

ii. Tendencies since the World War.

BRIEF REFERENCES:

Munro, The Five Republics of Central America, pp. 303-320.

Shepherd, Latin America, pp. 177-I 79.

Sweet, History of Latin America, pp. 269-271.

Verrill, Getting Together with Latin America, pp. 56-67. 


\section{LONGER ACCOUNTS:}

Chandler, Inter-American Acquaintances, pp. I-66.

Filsinger, Exporting to Latin America, pp. I-13, 310-313, 528-529.

Jones, Caribbean Interests of the United States, pp. 252-323.

O'Malley, Our South American Trade and Its Financing.

Pepper, American Foreign Trade.

Snyder, Selling in Foreign Markets.

Trade Thoughts of the Two Americas.

Bureau of Foreign AND Domestic Commerce:

Halsey, Investments in Latin America and the British West Indies. Special Agents Series, No. I69.

'Turner, Trade Developments in Latin America. Special Agents Series, No. 45.

b. Obstacles to American Commercial Success.

(I) The Obstacles of Assumption and Prejudice.

(a) Ignorance of Latin-American Conditions.

i. Absence of ties with southern nations.

ii. Historical reasons for mutual ignorance.

iii. Strangeness as the basis of trade difficulties.

(b) Inherent and Acquired Prejudices.

i. Results of racial and language differences.

ii. Dissimilarity of institutions and traditions.

iii. Effect of national pride and arrogance.

iv. Mutual reaction of United States expansion.

(2) Faults in American Business Methods.

(a) Business Practices Requiring Correction.

i. Indifference to Latin-American trade needs.

ii. Vacillating policies of American shippers.

iii. Faulty methods in salesmanship.

iv. Disregard of credit requirements.

v. Faulty packing and shipping practices.

(b) Weak Points in Business Policies.

i. Entrusting of commercial interests to foreigners.

ii. Lack of a definite national commercial policy.

iii. Absence of a national trade conscience. 
(c) Signs of Improving Trade Conditions.

i. Steps in Latin-American trade education.

ii. Partial realization of trade essentials.

\section{Special Accounts:}

Aughinbaugh, Selling Latin America, pp. 224-24I.

Filsinger, Exporting to Latin America, pp. 14-56.

Hough, Practical Exporting, pp. 42-79.

Verrill, Getting Together with Latin America, pp. 13-27.

Additional References:

Cooper, Understanding South America.

Foreign Relations of the United States, vols. for years concerned.

Pepper, American Foreign Trade.

Savay, Principles of Foreign Trade.

Snyder, Selling in Foreign Markets.

Vedder, American Methods in Foreign Trade.

Verrill, South and Central American Trade Conditions.

Bureau of Foreign AND Domestic Commerce:

Commercial Travelers in Latin America. Tariff Series, No. 35.

Consular Recommendations on South American Trade. Miscellaneous Series, No. 20.

Export Trade Suggestions. Miscellaneous Series, No. 35 .

3. Elements of Future Commercial Growth

a. Shipping Methods in Latin-American Trade.

(I) The Preparation of Goods for Export.

(a) Facilities for Exporting to Latin America.

i. Nature and functions of export commission houses.

ii. Establishment of export agencies.

iii. Effects on recent American trade.

(b) Factors in Determining Packing Methods.

i. Means and routes of transportation.

ii. Port conditions and transshipments.

iii. Conditions along routes of transit.

iv. Latin-American customs requirements. 
(c) Proper Marking of Goods.

i. Varying kinds of weight markings.

ii. Relation of marking to the duties levied.

iii. Correct addressing: government exactions.

(2) Shipping Requirements and Precautions.

(a) Insurance Considerations.

i. Types of commercial insurance.

ii. Liabilities of shipper, carrier, and customer.

(b) Kinds and Essentials of Shipping Papers.

i. Features of Latin-American invoices.

ii. Importance of correct papers.

iii. Determination of freight rates.

iv. Custom house regulations: clearances.

v. Details of business correspondence.

Special Accounts:

Aughinbaugh, Selling Latin Amcrica, pp. 31 1-330.

Filsinger, Exporting to Latin America, pp. 57-80, 137-200, 239-253.

Hough, Practical Exporting, pp. 286-539.

Additional REFERENCES:

Pepper, American Foreign Trade.

Savay, Principles of Foreign Trade.

Snyder, Selling in Forcign Markets.

South American Yearbook.

Vedder, American Methods in Foreign Trade.

Verrill, South and Central American Trade Conditions.

Bureau of Foreign and Domestic Commerce:

Packing for Export. Miscellaneous Series, No. 5.

South America as an Export Field. Special Agents Series, No. 8ז.

b. Considerations Essential to Commercial Success.

(I) The Matter of Banking and Credits.

(a) The Use and Abuse of Credit. Bancroft Library

i. The need of accuracy in quotations of terms.

ii. Necessity for long credits in Latin America.

iii. General dependability of Latin-American firms.

iv. Extension of credits and collections. 
(b) Banking Practices.

i. Kinds and usages of drafts.

ii. The use of time drafts in Latin America.

iii. Comparison of American and European practices.

(2) Methods of Building Business in Latin America.

(a) Advertising and Soliciting.

i. The advertising qualities required.

ii. The use of export journals, technical and news papers.

iii. Growth of the mail order business.

iv. Importance and essentials of catalogs.

v. Advantages of personal representation.

vi. Need of American emigration or residence abroad.

(b) Necessity for the Study of the Commercial Field.

i. Variations in markets and needs.

ii. Size of the field: geographic and climatic contrasts.

iii. Character and extent of competition.

iv. Nature of Latin-American needs and standards.

(c) The Question of Business Attitude.

i. Essentials of business organization.

ii. Importance of catering to desires and needs.

iii. Anticipation of slow market development.

Special Accounts:

Aughinbaugh, Selling Latin America, pp. 331-344.

Filsinger, Exporting to Latin America, pp. I4-32, 8I-123, 213-36I.

Hough, Practical Exporting, pp. II3-286, 540-6r4.

Verrill, Getting Together with Latin America, pp. 68-94.

ADDitional ReFERENCES:

Babson, The Future of South America.

Brooks, Foreign Exchange.

Cosby, Latin American Monetary and Exchange Conditions.

O'Malley, Our South American Trade and Its Financing.

Savay, Principles of Foreign Trade.

Snyder, Selling in Foreign Markets.

Vedder, American Methods in Foreign Trade. 
Bureau of Foreign and Domestic Commerce:

Commercial Travelers in Latin America. Tariff Series, No. 35.

Consular Recommendations on South American Trade. Miscellaneous Series, No. 20.

Hurley, Banking and Credit in South American Countries. Special Agents Series, No. 90.

MacElwee and Nichols, Training for Foreign Trade. Miscellaneous Series, No. 97 .

Sanger, Advertising Methods. Special Agents Series, Nos. 178, 185, 190. Snyder, Selling in Foreign Markets. Miscellaneous Series, No. 85.

c. Efforts toward Future Trade Development.

(I) Opportunities for Trade Development.

(a) The Scope and Nature of the Commercial Field.

i. Undeveloped natural resources in Latin America.

ii. Existing and latent markets.

iii. Varieties of investment opportunities.

iv. Latin-American governments as customers.

v. Products and manufactures salable in Latin America.

(b) Official Sources of Commercial Aid.

i. 'United States Government trade publications.

ii. Recent work of the Department of Commerce.

iii. The duties of United States consular agents and attachés.

(c) Semi-Official and Private Information Sources.

i. Activities of chambers of commerce.

ii. Aid offered by United States banks and corporations.

iii. The value of Latin-American directories.

(2) The Fostering of Pan-American Commercial Relations.

(a) The Official Channels of Activity.

i. Functions of the Pan-American Union.

ii. Trade bureaus and commercial associations.

(b) Latin-American Trade Conferences.

i. The nature and responsibility of trade conventions. 
ii. Their contributions to Latin-American trade.

iii. The bearing of trade relations on Pan-Americanism.

Special Accounts:

Aughinbaugh, Selling Latin America, pp. 345-374.

Filsinger, Exporting to Latin America, pp. 314-389.

Latané, The United States and Latin America, pp. 303-307.

Shepherd, Latin America, pp. 174-177.

\section{Additional READINGs:}

Babson, The Future of South America.

Barrett, Latin America, the Land of Opportunity.

Proceedings of the International Trade Conference (N. Y., 1915).

Proceedings of the National Foreign Trade Conventions (N. Y., 19141920).

\section{Bureau of Foreign and Domestic Commerce: Special} Agents Series:

Brand, Commercial Organizations, No. 60.

Harris, Central America as an Export Field, No. Ir3; cf. No. I4I.

Lough, Banking Opportunities in South America, No. ro6.

Wilson, South America as an Export Field, No. 8r.

[See Bibliography for yearbooks, commercial guides, etc.] 


\section{TOPICS FOR SPECIAL INVESTIGATION}

\section{Spanish Colonial Methods.}

I. Pre-Spanish Indian Civilization.

2. The Asiento and Its Abuse.

3. Treatment of the Aborigines.

4. Evolution of Colonial Offices.

5. Comparison of Spanish and English Colonial Methods.

6. Missions and the Inquisition.

7. Expulsion of the Jesuits.

8. Colonial Labor Laws and Customs.

9. The Policy of Divide et Impera.

Development of the Latin-American Republics.

Political Development and Problems in Particular States.

10. The Patronage.

Ir. Church Influence in Politics.

12. Parties and Party Issues.

Agricultural and Industrial Development (Individual

Nations).

13. Grazing and the Export Trade.

14. History of the Rubber Industry.

15. Growth of the Banana Industry.

I6. Survey of Coffee Culture.

17. Minerals and Their Exploitation.

Social Problems.

18. Development of Education.

19. Relation of Church and State.

20. Problems of Immigration and Assimilation.

2 r. The War Against Disease.

22. Character and Influence of the Press. 


\section{Inter-American AND Foreign Relations.}

Latin-American Problems.

23. The Tacna-Arica Controversy.

24. The A B C Alliance.

25. The Panama-Colombia Controversy.

26. Latin-American Attitude toward the War.

Political Relations of the United States.

Hegemony of the United States in:-

27. Cuba (since 1902).

28. Central America (since r903).

29. The Dominican Republic (since 1904).

30. Ecuador and Peru (since 1903).

3r. Haiti (since 19I4).

32. Mexico (since r9o0).

33. Nicaragua: Canal Projects.

The Monroe Doctrine.

34. Raison d'etre of the Original Doctrine.

35. European Attitude toward the Monroe Doctrine.

36. Latin-American Attitude toward the Monroe Doctrine.

37. Pan-Americanism.

38. Latin America and the League of Nations.

Diplomatic Relations.

39. History of the Platt Amendment.

40. Diplomatic History of the Panama Canal.

4r. The Venezuela Controversy.

42. The French Invasion of Mexico.

Industrial AND Commercial Conditions.

United States Business Relations.

43. Present Obstacles of Assumption, Prejudice, and Practice.

44. American Methods in Salesmanship.

45. Agencies and Branch Houses.

46. Credit Facilities and Investments.

47. Training for Latin-American Salesmanship. 
Foreign Interests in Latin America.

48. German Business Methods in Latin America.

49. Beginnings of Japanese Competition.

50. British Ways of Doing Business.

5r. European Capital in Latin-American Industries.

52. European Banking Methods in Latin America.

Latin-American Practices and Trade Conditions.

53. The Recent Use and Abuse of Trade Marks.

54. Social Usages in Business.

55. Latin-American Credits.

56. Advertising in Latin America.

57. Latin-American Tariff Systems.

58. Business Policies of Latin-American Importers.

59. Transportation Methods in Latin America.

6o. Latin-American Port Facilities. 



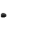




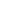



$-$ 


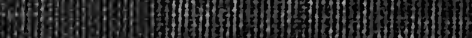

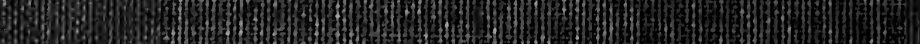

sis

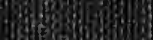

Fon.

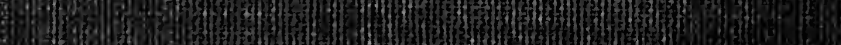

